\title{
ETIOLOGY OF SEEDLING BLIGHT AND ROOT ROT OF \\ FABA BEAN (VICIA FABA) IN MANITOBA
}

\author{
A Thesis \\ Submitted to the Faculty \\ of \\ Graduate Studies \\ The University of Manitoba \\ by \\ Lakhdar Lamari \\ In Partial Fulfillment of the \\ Requirements for the Degree \\ of \\ Master of Science \\ Department of Plant Science \\ May 1982
}


NOTICE

THE QUALITY OF THIS MICROFICHE DEPENDS UPON

THE QUALITY OF THE PRINT OF THE THESIS

SUBMITTED FOR FILMING, THIS THESIS HAS BEEN

MICROREPRODUCED AS RECEIVED, ANY OMISSIONS IN

THE TEXT (E. $\underline{G}_{1}$, COLOURED PLATES) ARE NOTED IN

THE APPROPRIATE PLACE IN THE FILM.

REPRODUCTION IN FULL OR IN PART OF THIS FILM IS

GOVERNED BY THE CANADIAN COPYRIGHT ACT, R.S.C. 1970,

C. $C-30$, PLEASE READ THE AUTHORIZATION FORM WHICH

ACCOMPANIES THIS THESIS,

THIS THESIS WAS FILMED IN THE DEPARTMENT OF ARCHIVES

AND SPECIAL COLLECTIONS, ELIZABETH DAFOE LIBRARY, UNIVERSITY OF MANITOBA, WINNIPEG, MANITOBA, CANADA, 


\section{ETIOLOGY OF SEEDLING BLIGHT AND ROOT ROT OF \\ FABA BEAN (VICIA FABA) IN MANITOBA}

BY

LAKHDAR LAMARI

A thesis submitted to the Faculty of Graduate Studies of the University of Manitoba in partial fulfillment of the requirements of the degree of

MASTER OF SCIENCE

(ㄷ) 1982

Permission has been granted to the LIBRARY OF THE UNIVERSITY OF MANITOBA to lend or sell copies of this thesis, to the NATIONAL LIBRARY OF CANADA to microfilm this thesis and to lend or sell copies of the film, and UNIVERSITY MICROFILMS to publish an abstract of this thesis.

The author reserves other publication rights, and neither the thesis nor extensive extracts from it may be printed or otherwise reproduced without the author's written permission. 
FOREWORD

The materials, methods and results in this thesis are presented in the form of three manuscripts intended for publication in the Canadian Journal of Plant Pathology. The style as well as the preparation of tables and figures comply with the requirements of the journal. A general discussion of the results is included after the manuscripts. 


\section{ACKNOWLEDGEMENTS}

I wish to express my sincere gratitude to Dr. C.C. Bernier for his guidance and encouragement throughout the course of this research project.

Special thanks are due to Dr. J. Reid (Head, Department of Botany, University of Manitoba). The supply of several Fusarium spp. cultures as well as his valuable help in mycological subjects is gratefully a cknowledged.

I also wish to express special thanks to Dr. S.R. Rimmer and Dr. P. McVetty for their help and advice throughout the duration of this study. Thanks are extended to Dr. R.L. Conner (formerly of the U of M) for kindly supplying all Vicia and Lathyrus spp. used in this study.

The technical assistance provided by Mr. R.B. Smith and Ms. L. Harrison and the help offered by Mrs. M.L. Alsip in the preparation of the thesis are gratefully acknowledged.

I express my gratitude to the International Development and Research Center (I.D.R.C.) for the financial support provided for all the duration of my research program. Mr. N. Kadra and Dr. L. Hachemi, respectively former and present Director of the Institut de Develofpement des Grandes Cultures (I.D.G.C.) are sincerely thanked for allowing and extending my leave from the I.D.G.C.

Finally, I wish to express my thanks to Mrs. D. Lapsley for typing the thesis. 
LIST OF TABLES $\ldots \ldots \ldots \ldots \ldots \ldots \ldots \ldots \ldots \ldots \ldots \ldots \ldots \ldots \ldots \ldots \ldots \ldots \ldots$

LIST OF FIGURES $\ldots \ldots \ldots \ldots \ldots \ldots \ldots \ldots \ldots \ldots \ldots \ldots \ldots \ldots \ldots \ldots \ldots \ldots \ldots$

GENERAL ABSTRACT $\ldots \ldots \ldots \ldots \ldots \ldots \ldots \ldots \ldots \ldots \ldots \ldots \ldots \ldots \ldots \ldots \ldots \ldots \ldots$

GENERAL INTRODUCTION $\ldots \ldots \ldots \ldots \ldots \ldots \ldots \ldots \ldots \ldots \ldots \ldots \ldots \ldots \ldots$

REVIEW OF LITERATURE $\ldots \ldots \ldots \ldots \ldots \ldots \ldots \ldots \ldots \ldots \ldots \ldots \ldots \ldots \ldots \ldots \ldots \ldots$

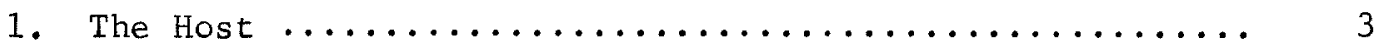

1.1 Origin and History $\ldots \ldots \ldots \ldots \ldots \ldots \ldots \ldots \ldots \ldots \ldots \ldots$

1.2 Seedling Blight and Root Rot of Faba Beans ........ 4

2. Aphanomyces euteiches $\ldots \ldots \ldots \ldots \ldots \ldots \ldots \ldots \ldots \ldots \ldots$

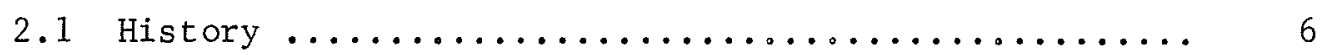

2.2 Isolation of Aphanomyces euteiches from Peas ...... 7

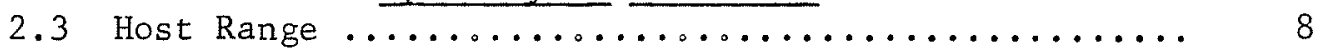

2.4 Pathogenic Variability and Host Specialization ..... 10

2.5 Survival and Epidemiology of A. euteiches ......... 12

3. Factors Affecting the Development of Disease

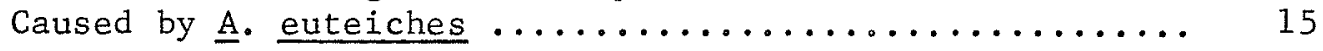

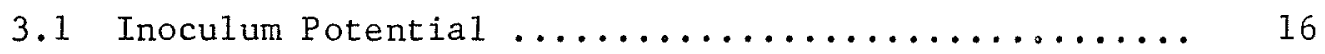

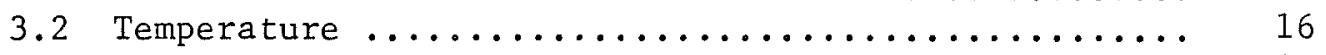

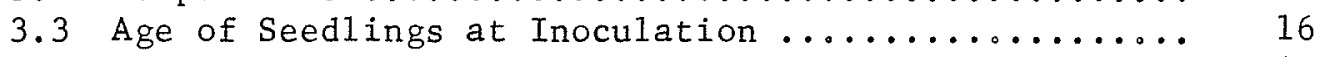

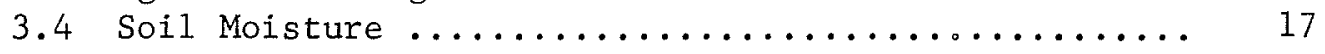

4. Control of Aphanomyces Root Rot of Peas ............ 17

4.1 Search for Tolerance to $A$. euteiches in Peas ...... 17

4.2 Control of A. euteiches with Fungicides .......... 19

4.3 Control of $\underline{\text { A. euteiches }}$ by Herbicide Treatments .... 20

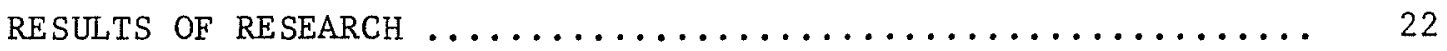

1. Etiology of Seedling Blight and Root Rot of Faba Bean

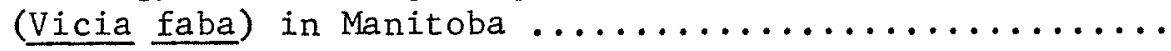


PAGE

2. Host Range and Pathogenic Variability of

Aphanomyces euteiches Isolates From Faba Bean ........ 46

3. Screening Faba Bean (Vicia faba) for Tolerance to Rot Caused by Aphanomyces euteiches .............66 68

GENERAL DISCUSSION $\ldots \ldots \ldots \ldots \ldots \ldots \ldots \ldots \ldots \ldots \ldots \ldots \ldots \ldots$

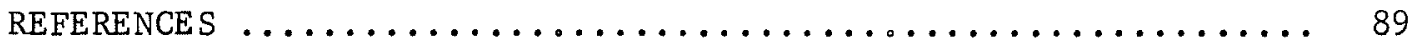

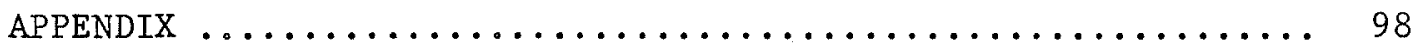


LIST OF TABLES

TABLE

PAGE

Paper 1

1 Fungal species isolated from diseased faba bean seedlings in experimental plots at the University

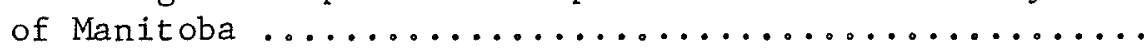

2 Response of leguminous and non-leguminous species and cultivars to Aphanomyces root rot in a naturally infested field at the University of Manitoba ........ 30

3 Stem and seed infection of two faba bean and two field pea cultivars inoculated with 10 isolates of

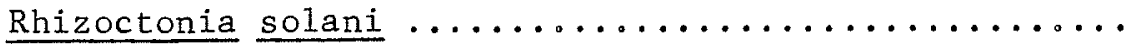

4 Response of three faba bean and one field pea cultivars to inoculation with mycelium of an Aphanomyces sp.

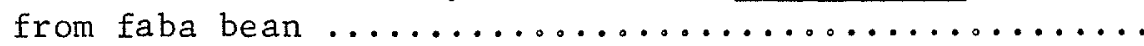

Paper 2

1 Response of leguminous and non-leguminous species to inoculation by Aphanomyces euteiches from Vicia faba ..

2 Response of 12 legume cultivars to inoculation with a faba bean isolate ( $\mathrm{AE} 1$ ) and a Wisconsin pea isolate

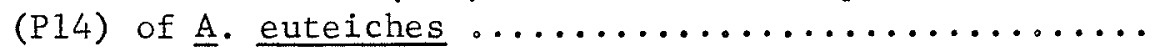

3 Isolation of Aphanomyces euteiches from infested soil samples assayed in the greenhouse ............... 64

Paper 3

1 Effect of Aphanomyces root rot on the yield of five licensed faba bean cultivars ................ 76

2 Effect of Aphanomyces root rot on the fresh shoot weight of five licensed faba bean cultivars ........ 77

3 Comparative yield of tolerant selections and licensed cultivars in an Aphanomyces-infested soil ......... 81

4 Effect of fungicide seed treatments on the emergence of the faba bean cultivar Ackerperle in soil naturally infested with Aphanomyces euteiches and Rhizoctonia

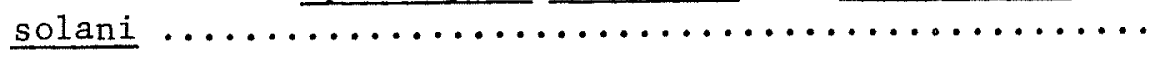


5 Effect of fungicide seed treatments on the stand, disease severity index and fresh shoot weight of the cultivar Diana in soil naturally infested with Aphanomyces euteiches and Rhizoctonia solani $\ldots . . \ldots$ 


\section{LIST OF FIGURES}

Paper 1

1 Oospores of Aphanomyces sp. in an infected root of the faba bean cultivar PI $222128 \ldots \ldots \ldots \ldots \ldots \ldots \ldots \ldots$.

2 Symptoms induced by Rhizoctonia solani in plants of

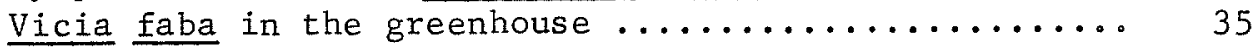

3 Symptoms induced by Aphanomyces euteiches in plants of Vicia faba in the field and in the greenhouse .... 38

4 Vegetative and reproductive structures of Aphanomyces euteiches isolated from Vicia faba $\ldots \ldots \ldots \ldots \ldots \ldots .41$

\section{Paper 2}

1 Virulence patterns of a faba bean isolate (AE1) and a Wisconsin pea isolate (P14) of Aphanomyces euteiches

on five legume cultivars ................... 55

2 Virulence patterns of isolates of Aphanomyces euteiches from the University of Manitoba in six

legume cultivars ...................... 57

3 Effect of seedling age at the time of inoculation on

disease development ...................... 59

4 Effect of inoculum concentration on disease develop-

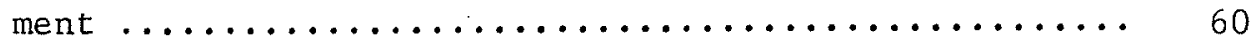

5 Effect of temperature on disease development ....... 61

6 Effect of the growth stage of naturally infected faba bean plants on the frequency of isolation of Aphanomyces euteiches $\ldots \ldots \ldots \ldots \ldots \ldots \ldots \ldots \ldots \ldots 63$

Paper 3

1 Frequency distribution of faba bean accessions in response to Aphanomyces root rot $\ldots \ldots \ldots \ldots \ldots \ldots \ldots . \ldots 78$ 
GENERAL ABSTRACT

Lamari, Lakhdar. M.Sc., The University of Manitoba, March, 1982. Etiology of Seedling Blight and Root Rot of Faba Beans (Vicia faba)

in Manitoba. Major Professor; C.C. Bernier.

A severe seedling blight and root rot of faba bean (Vicia faba L.) has been observed since 1978 in experimental plots at the University of Manitoba ( $U$ of $M$ ) and in some commercial faba bean fields in Eastern Manitoba. Aphanomyces euteiches Drechs. was found to be the main agent of the disease at the $U$ of M Campus farm, where faba bean root rot was consistently severe. Rhizoctonia solani Kuehn. was isolated from plants of faba bean and other crops infected at different locations. The pathogenic isolates of $\underline{R}$. Solani caused damping-off of faba bean plants except for one isolate recovered in Eastern Manitoba. The latter caused a soft rot of the stem and roots and was more aggressive than any of the other isolates. A Fusarium tentatively identified as $\underline{F}$. avenaceum (Fr.) Sacc. was recovered from mature faba bean plants in Eastern Manitoba and found to be pathogenic to faba bean and peas in the greenhouse.

In addition to $\underline{\mathrm{V}}$. $\underline{\text { faba }}, 12$ leguminous species were infected by $\underline{\mathrm{A}}$. euteiches. The following species were infected and do not appear to have been previously reported as hosts of this fungus: Lathyrus ochroleucus Hook., L. sativus L., Lens culinaris Medic., Vicia calcarata Desf., $\underline{V}$. cracca L., $\underline{\text {. disperma }}$ D.C., $\underline{V}$. narbonensis L. and $\underline{V}$. tetrasperma Schreber. The faba bean type isolate (AE1) differed in pathogenicity 
from a Wisconsin pea isolate (P14). The latter was avirulent on faba bean. Three pathotypes were identified among the Manitoba isolates of A. euteiches. Pathotypes AE1, $A E 2$ and $A E 3$ were pathogenic to peas; pathotypes $\mathrm{AE} 1$ and $\mathrm{AE} 2$ were distinguished by a pea cultivar and AE3 was not virulent on faba bean and lentils.

Tolerance to Aphanomyces root rot was found in the licensed cultivars Ackerperle and Herz Freya but not in Diana and Erfordia. Variability in tolerance to root rot was also found in some 350 faba bean accessions. The following accessions were considered tolerant after two seasons of field testing: 2N19, 2N21, 2N37, 2N66, 2N94, 2N104, $2 \mathrm{N112}, 2 \mathrm{N114}, 2 \mathrm{N116}, 2 \mathrm{~N} 134,2 \mathrm{~N} 140,2 \mathrm{~N} 218,2 \mathrm{~N} 236,2 \mathrm{~N} 296, \mathrm{DN} 75-38$ (ERF) and DN76-8. Partial control of Aphanomyces root rot was achieved for 5 weeks by seed treatment with the fungicide Dowco 444 only. 
GENERAL INTRODUCTION

Root diseases of faba beans (Vicia faba $L_{0}$ ) have been reported in many parts of the world where the crop is grown. Wilts were found to be caused by at least three highly specialized species of Fusarium (Yu, 1944; Yu and Fang, 1948; Schneider and Dalchow, 1975) and root rots involved a wide variety of organisms. These include Rhizoctonia solani Kuehn., Pythium spp., Fusarium spp. (Sa1t and Hornby, 197la,b; Platford and Bernier, 1973; Bernier, 1975; Lu and Thibodeau, 1978). Fusarium solani f. sp. fabae (Yu and Fang) was found to be specialized on $\underline{V}$. faba and was reported to occur in China (Yu and Fang, 1948), Japan (Yamamoto et al., 1955) and the Sudan (Ibrahim and Hussein, 1974). In Rothamsted, England, root rot and wilt were also caused by Phytophthora megasperma Drechs. (Salt and Hornby, 1971a,b).

Early surveys in Manitoba indicated that root rot incidence was low (Bernier, 1975). However, root rot and seedling blight were severe from 1977 to 1981 in experimental field plots at the University of Manitoba (U of M). Root rot was also found to occur in some commercial fields in Eastern Manitoba in 1978 and 1979 (G. Platford, personal communication).

This study was initiated to provide information on the organisms causing the disease in Manitoba. The first section deals with the etiology of the disease and includes the isolation, identification and pathogenicity tests of the organisms associated with root rot. The second section deals with Aphanomyces euteiches, the pathogen found to 
cause root rot of faba beans in the field at the $U$ of $M$. The host range of the isolate $A E 1$ and the pathogenic variability among the isolates recovered in Manitoba were investigated. The third section reports on the screening in the field of some 350 faba bean accessions for tolerance to $\underline{A}$. euteiches, as well as on the evaluation of several seed treatment fungicides for the control of seed rot and seedling blight。 


\section{REVIEW OF LITERATURE}

1. The Host

\subsection{Origin and History}

Faba bean (Vicia faba L.) is an important pulse crop and ranks fourth only to dry beans, dry peas and chickpeas on a worldwide basis (Hawtin and Stewart, 1979). Faba bean is thought to have been first cultivated in the late neolithic period (Schultze-Motel, 1973; Zohary and Hopf, 1973). From its near eastern centre of origin, Vicia faba spread to all the Mediterranean Basin, Abyssinia, Europe and Asia (Cubero, 1974). Most of the world's faba beans are now grown in China, Northern Africa, the Middle East and, to a lesser extent, in Southern Europe (Hawtin and Stewart, 1979) and Western North America (Evans and Slinkard, 1975).

The division of $\underline{V}$. faba into three subspecies, i.e. major, equina and minor is based on the seed size. All three subspecies are cross compatible. They are used for human and animal consumption because of their high protein content.

Faba beans have been found to be well adapted to the moister portions of the cereal growing areas in Western Canada (Evans et al. , 1972). Their ability to fix nitrogen when inoculated with suitable Rhizobium bacteria makes them a potentially attractive high protein crop for Manitoba (Candlish and Clark, 1975).

Small seeded types can be handled with standard cereal machinery 
and are, therefore, preferred to the larger-seeded types, particularly in mechanized agriculture.

The development of faba beans in Western Canada for animal feed is likely to be influenced by the prices of high protein animal meals imported from the USA. Faba bean acreage has been significantly reduced in the United Kingdom (Bond, 1979) and Spain (Cubero, 1979) partly because of the import of cheap high protein animal feed.

Several diseases of faba bean occurring in the Middle East and Europe have also been reported to occur in Canada. These include Ascochyta leaf and pod spot, chocolate spot caused by Botrytis spp., rust, powdery mildew and several virus diseases (Bernier, 1975; Lu and Thibodeau, 1978). Seedling blight and root rots were generally low in Manitoba in 1974, but it was thought that faba beans might be as prone as peas to root diseases and long rotations were recommended to prevent diseases from building up (Bernier, 1975).

\subsection{Seedling Blight and Root Rot of Faba Beans}

Several pathogens have been associated with faba bean root diseases in many parts of the world. Along with other diseases, root rots and wilts are thought to be a major problem in West Asia and North Africa, especially those caused by Fusarium spp., Rhizoctonia solani Kuehn and the Sclerotinia spp. (Hawtin and Stewart, 1979).

Faba beans have been found to be susceptible to wilt caused by several Fusarium spp. Fusarium vasinfectum Atk. was possibly the first species reported to cause wilt of Vicia faba in Belgium (Marchal and Verplancke, 1926). Fusarium oxysporum Schl. f. sp. fabae Yu and Fang has been reported to cause wilt in China (Yu and Fang, 1948), Japan (Ikata, 1951; Yamamoto et al. 1955), Canada (Coulombe, 1957), Russia (Dunin, 1962) 
and Egypt (Ibrahim and Abdel Rehim, 1965). Another wilt was caused by F. avenaceum (Fr.) Sacc. f. sp. fabae Yu in China (Yu, 1944) and Japan (Yamamoto et al., 1955) and by a new species, Fusarium inflexum Schneider in Germany (Schneider and Dalchow, 1975). F. inflexum did not infect Vicia sativa $L$., V. Villosa Roth., Pisum sativum L., Lupinus albus L., L. Iuteus L., L. angustifolius L., Phaseolus vulgaris L., Cajanus indicus Spreng. and Crotalaria juncea L. and was, therefore, thought to be specialized on $\underline{V}$.

Wilt Fusaria are usually restricted to their hosts but may cause disease on related host species. F. oxysporum f. sp. pisi (Linford) Snyd. and Hans. race 1 has been reported to mildly infect $\underline{V}$. faba (Linford, 1928) but such infection could not be reproduced by Schneider and Dalchow (1975).

Root rot is usually caused by pathogens with a wider host range than the wilt organisms, with the exception of Fusarium solani fosp. fabae (Yu and Fang, 1948; Yamamoto et al., 1955; Ibrahim and Hussein, 1974).

In Rothamsted, England, several fungal pathogens and nematodes have been observed in faba bean infected roots. These include the stem eelworm (Ditylenchus dipsaci Kuehn.), species of Pythium, Fusarium,

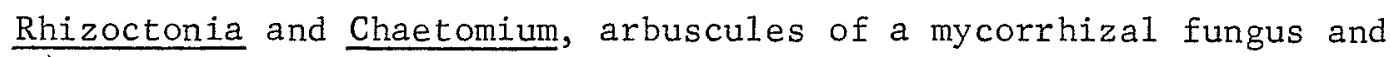
oospores of Olpidium brassicae (Woron.) Dang. and Phytophthora megasperma Drechs. Only $\underline{\mathrm{P}}$. megasperma actually caused wilt and root decay of faba bean when tested in pot experiments (Salt and Hornby, 1971a,b). McEwen et a1. (1973) reported the isolation of Cylindrocarpon spp., bacteria, $\underline{F}$. oxysporum, F. avenaceum, Pythium spp. and $\underline{\text { Phoma }}$ sp. from discolored lesions on stem bases of faba beans. 
In Egypt, species of Fusarium and Rhizoctonia solani were reported to be associated with root diseases of faba beans (Aly, 1967; Abdallah, 1969). Abd El Rahim (1962) found that root rot and wilt were caused by $\underline{F}$. oxysporum, F. Solani, Erwinia carotovora (Jones and Holland) and Pseudomonas polygoni (Thornberry and Anderson).

In Manitoba and Quebec, root rot was generally low and was caused by several Fusarium spp., ‥ solani, Sclerotinia sclerotiorum (Lib.) de Bary and Pythum spp. (Platford and Bernier, 1973; Bernier, 1975; Lu and (Thibodeau, 1978).

Faba bean roots turn black in response to infection by pathogens, mechanical damage or just by exposure to air, making symptoms caused by different pathogens appear similar. McEwen et al. (1981), however, recognized two types of black roots: (i) a wet rot of the root cortex caused mainly by oomyceteous pathogens and (ii) a dry rot in which the cortex becomes black or dark brown but does not disintegrate, which is caused by several members of the Fungi Imperfecti. This latter type of symptom was found to precede normal senescence but could be detected earlier when host resistance was decreased by stress from other causes.

\section{Aphanomyces euteiches}

\subsection{History}

The genus Aphanomyces was established by de Bary (1860) and was included in the Saprolegniales. Most species in this genus have some parasitic tendencies on fish, algae, fungi and on phanerogamous plants (Coker, 1923). A detailed taxonomic study of the Saprolegniales including some species of Aphanomyces was published (Coker, 1923). The 1ist of Aphanomyces species was updated by Sparrow (1960) and a monograph 
of this genus was published by Scott (1961).

Aphanomyces euteiches was first described by Jones and Drechsler (1925) and recognized as the causal agent of the common root rot of peas. Surveys indicated that Aphanomyces euteiches was present in nearly a11 pea-growing areas in the USA, where it was and is still considered to be a limiting factor for pea cultivation (Papavizas and Ayers, 1974). It has also been reported to occur in various parts of the world where peas are cultivated. It was found in France, England and Wales, Norway, Sweden, Denmark, the USSR, Jamaica and Australia (Papavizas and Ayers, 1974). It has also caused pea root rot in Eastern Canada (Ontario and Quebec), but was considered to be an unimportant pathogen in Ontario (Conners, 1967).

The disease symptoms on peas have been thoroughly described (Jones and Drechsler, 1925). Above ground symptoms are not necessarily unique to A. euteiches. Stunting, wilting of the lower leaves, sudden wilting of the whole plant or weak adult plants are found to be caused by this pathogen. The disease can be better diagnosed through observation of the underground parts. This includes a pale yellow discoloration of early infected basal stem and root tissues, followed by a soft decay of the cortical tissue. If such infected plants are pulled, the stem fails to break at the seed and the vascular cylinder is very often pulled out with the plants. Microscopic observation of the root and basal stem always reveals the presence of typical oospores.

\subsection{Isolation of Aphanomyces euteiches from Peas}

The isolation of Aphanomyces spp. and of A. euteiches in particular has been difficult. Pea root rot was solely attributed to Pythium when it was a complex of Pythium sp. and $\underline{A}$. euteiches (Jones and Drechsler, 
1925). Two major difficulties are encountered: i) bacterial contamination to which Aphanomyces spp. are very sensitive and ii) contamination by other fungi associated in the root rot complex, such as Pythium spp.,

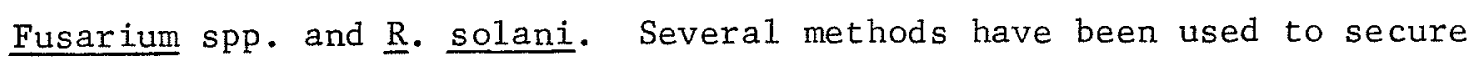
pure cultures of the fungus. Jones and Drechsler (1925) used segments of freshly infected root tissue and made several transfers of the ones where they could microscopically detect hyphae full of granular material. Sherwood (1958) used the ability of Aphanomyces to produce zoospores and infect sterile corn kernels in petri dishes containing sterile water. Streptomycin was also used to secure bacteria-free cultures (Sundheim, 1972). No techniques have been developed to separate Aphanomyces spp. from fungal contaminants.

In their descriptive paper, Jones and Drechsler (1925) noted that the mycelium transferred its content into oospores which are formed upon the destruction of the host cells. After this stage it was almost impossible to secure growth on culture media. Thus, recovery of $\mathrm{A}$. euteiches is only possible if isolation attempts are done using newly infected seedlings.

\subsection{Host Range}

Since its isolation and description (Jones and Drechsler, 1925), A. euteiches has been tested against several plant species. More than 80 species from 19 families have been reported to be hosts of $\underline{A}$. euteiches. An extensive list of these hosts has been compiled (Papavizas and Ayers, 1974). One of the earliest work on the host range of this species has been done by Linford (1927), who showed that Medicago sativa L., Melilotus alba Desr., Lathyrus odoratus L., L. Latifolius L.,

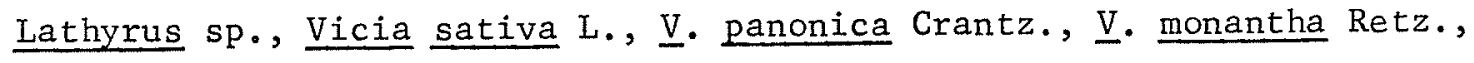




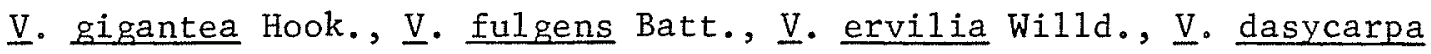
Ten. and $\underline{V}$ angustifolia $L$. could be parasitized in naturally infested soil. In later studies, often by pure cultures of the pathogen in sterile sand or soil (Sherwood and Hagedorn, 1962) or by the excised root tip method (Carlson, 1965), species of many families were found to be parasitized by $\underline{A}$. euteiches. The families involved were the Alismataceae (Ridings and Zettler, 1973), Amaranthaceae (Sherwood and Hagedorn, 1962; Carlson, 1965), Caryophyllaceae (Carlson, 1965), Chenopodiaceae (Sherwood and Hagedorn, 1962; Carlson, 1965), Compositae, Cruciferae, Cucurbitaceae (Car1son, 1965), Gramineae (Geach, 1936; Carlson, 1965; Carley, 1969; Haensler, 1976), Leguminosae (Haensler, 1926; Linford, 1927; Geach, 1936; Sherwood and Hagedorn, 1962;

Schmitthener, 1964; Carlson, 1965; Carley, 1969; Pfender and Hagedorn, 1980), Liliaceae (Carlson, 1965), Malvaceae (Carlson, 1965); Pinaceae (Eliason, 1928), Polygonaceae, Portulacaceae, Scrophulariaceae, Solanaceae, Umbelliferae and Violaceae (Carlson, 1965). Some discrepancies have been noted in the list published by Papavizas and Ayers (1974); these include infection of non-leguminous plants by $\underline{A}$. euteiches in non-sterile soil. Tomato was infected by Aphanomyces cladogamous Drechs. (McKeen, 1952) and not by $\underline{A}$. euteiches Drechs. A. cladogamous was isolated and described by Drechsler (1929) and was found later in roots of spinach and flax (Drechsler, 1935)。 Field infections of lettuce, pepper and eggplant were caused by an Aphanomyces sp. which Mix (1945) did not identify at the species level. Because of its host range, $\underline{A}$. cladogamus would be a better candidate than A. euteiches, which has been mainly reported on leguminous species. The severity of the disease described by Mix (1945) led 
McKeen (1952) to the conclusion that Mix's isolate did not represent the same species as the one isolated from tomato and which did not cause severe damage. Pathogenic variability has been found to exist in A. euteiches (Beute and Lockwood, 1967; Sundheim, 1973) and in A. cochlioides (Buchholtz and Meredith, 1944). It is likely that such variability exists in $\underline{\text { A }}$ cladogamous.

In the case of the Dutch isolate, "A. euteiches P.F. 2", isolated from pansies, Arabis and spinach (Meurs, 1929), it appears that $\underline{A}$. cladogamous was probably the pathogen involved and that Meur's isolate was not $\underline{A}$. euteiches, the pathogen isolated from peas (Drechsler, 1954). Later work showed that "A. euteiches P.F.2" was only slightly pathogenic to pansies in Holland, whereas Brevilegnia gracilis and $\underline{B}$. macrospora caused severe root rot (Van Eek, 1938).

The infection of celery by $\underline{A}$. euteiches in naturally infested soil, reported by Doran et al. (1942), was questioned by Drechsler (1954) in view of the fact that no detailed evidence had been given.

It would then appear that there is very little or only poor evidence for the infection of non-leguminous plants by $\underline{A}$. euteiches in naturally infested fields or in non-sterile soils. This does not prove that $\underline{A}$. euteiches has a strong tendency towards leguminous species, but it does suggest it. Reports on the host range of this pathogen still contain contradictory information (Papavizas and Ayers, 1974). This may be partly due to different inoculation techniques and to different pathotypes of the fungus used, the inoculation technique probably being the most important factor leading to contradictory results; these ranged from planting the host in naturally infested soil (Linford, 1927) to inoculation of whole plants in sterile sand (Sherwood and Hagedorn, 
1962) and inoculation of excised root tips (Carlson, 1965).

\subsection{Pathogenic Variability and Host Specialization}

Whether isolates of $\underline{A}$. euteiches are restricted to a certain number of hosts remains an unanswered question. The first level of specialization that has been reported is the ability of $\underline{A}$ e euteiches to infect differentially at the species level. Sherwood and Hagedorn (1962) found that one of their isolates infected Lotus corniculatus L., Onobrychia viciifolia Scop., Trifolium hybridum L. and $\underline{V}$. pannonica, whereas another isolate parasitized only Trifolium pratense L. and Amaranthus

retroflexus L. Both isolates were pathogenic to peas (Pisum sativum L.). The Amazon sword plant isolate (Ridings and Zettler, 1973) was able to infect pea (Pisum sativum), broadbean (Vicia faba), beets (Beta vulgaris L.), cowpea (Vigna sinensis L.) and radish (Raphanus sativus L.), whereas the pea isolates $\mathrm{AE} 6$ and $\mathrm{AE} 7$ to which they compared their isolate, were restricted to peas. Physiologic specialization has also been found by Carlson (1965) in inoculations of non-leguminous species by the excised root tip method.

A second level of variability is the ability of A. euteiches to differentially infect a set of pea cultivars. Although the first report is attributable to King and Bissonnette (1954), the most extensive report is due to Beute and Lockwood (1967) who used six pea lines as differential series and tested 15 single spore isolates from several locations. The authors were able to identify two races ( 1 and 2 ). Both races were pathogenic on peas since they were differentiated by the percentage of pea seedlings killed each day, for nearly 2 weeks. The same method was used by Sundheim (1972) in Norway. He identified four races including race 1 of Beute and Lockwood. The other races were designated 
3,4 and 5 .

Determination of races with a bean series (Phaseolus spp.) has been attempted (Carley, 1969). Seven races were detected but the results of the experiment were highly variable due to the use of unknown inoculum levels. The race concept of $\underline{A}$. euteiches has not been assessed for validity and no further work has been reported in this area since 1972 . In addition to the reports on races, several studies showed that variability in aggressiveness on peas existed in this pathogen (Lockwood, 1960a; Scharen, 1960; Haglund and King, 1961; Carlson, 1965; Shehata et $\underline{\text { a1. }}, 1976$ ).

The existence of pathogenic variability raises the question of the mechanisms of variation in this pathogen. There are so far no reported studies on this subject, nor on any other genetical aspect in this fungus. As reported for other oomycetes (Sansome, 1961, 1962, 1965; Barksdale, 1966, 1968; Bryan and Howard, 1969), Aphanomyces spp. may be diploid in its vegetative phase. Cytological evidence of gametangial meiosis has been provided by Traquair and McKeen (1980)。

\subsection{Survival and Epidemiology of A. euteiches}

Long rotations up to 10 years without peas, have decreased disease severity but did not eliminate Aphanomyces root rot (Jones and Linford, 1925; Temp, 1966). Laboratory studies showed that oospores were able to survive 2 years of alternate or continuous freezing without losing their pathogenicity (Sherwood and Hagedorn, 1962). This confirms the belief that the thick-walled oospore of $\underline{A}$. euteiches represents the survival unit of this pathogen. Previous work by Scharen (1960) showed that oospores embedded in plant debris could be induced to germinate if buried next to the roots of several plant species and that germina- 
tion was highest next to pea roots. Zoospores which were produced were used to infect pea plants and proved pathogenic. Although zoospores were used in almost all infection studies, this was the first report which demonstrated the infection role of the zoospores and confirmed the role of the oospore in the survival of $\underline{A}$. euteiches.

Sherwood and Hagedorn (1958) designed a method for indexing soil for disease prior to planting. Soil was sampled from commercial fields, planted with a susceptible pea cultivar in the greenhouse and scored for disease. Three types of fields were distinguished on the basis of the greenhouse disease severity index (DSI): i) safe for planting $(D S I=0-50 \%)$, ii $)$ questionable $(D S I=51-69 \%)$ and $i i i)$ hazardous (DSI $=70-100 \%)$. The indexing system was elaborated earlier for sugar beets (Fink, 1948; Fink and Buchholtz, 1954) and later adapted for peas (Johnson, 1953, 1957). Good correlations were obtained between DSI's obtained in the greenhouse and those obtained in the fields from which the samples were taken (Reiling et al., 1960). Furthermore, the number of debris containing oospores/100 $\mathrm{g}$ of soil has been shown to be positively correlated to the DSI observed in the greenhouse and field (Boosalis and Scharen, 1959).

Another approach to the quantitative estimation of $\underline{A}$. euteiches in soil used by Mitchell et al. (1969) is thought to be sensitive in detecting Aphanomyces in plant debris previously separated from soil by a sieving method (Boosalis and Scharen, 1960). This method consisted in putting susceptible pea seedlings in contact with the plant debris in moist paper towels. Observation and/or isolation of $\underline{A}$. euteiches is thus rendered easier.

Despite these findings, little is known about the dynamics of inoculum in situ mainly because there are no consistent methods of 
recovering and enumerating propagules of $\underline{A}$. euteiches directly from soil without baiting with a susceptible host.

The survival of A. euteiches in soil for long periods in the absence of peas has been a subject of speculation. Several workers consider that the wide host range of this pathogen is likely to play a role in its persistence in soil despite long rotations. Thus, the concept of alternative hosts has been suggested (Linford, 1927; Sherwood and Hagedorn, 1962; Car1son, 1965; Carley, 1969). The contradictory information on the host range of $\underline{A}$. euteiches is consequently reflected in the alternate host concept. For instance, Sherwood and Hagedorn (1962) thought that "parasitization of legumes other than peas might play a role in the perpetuation of $\underline{A}$. euteiches and that non-leguminous plants apparently are not suitable hosts". Carlson (1965), on the other hand, believed that even non-leguminous hosts might play a role. This apparent disagreement seems to result from the inoculation techniques used in each case. The excised root tip method (Carlson, 1965) indicated that many host families could be parasitized. Infections of whole plants grown in sterile sand (Sherwood and Hagedorn, 1962) were positive mainly on leguminous species and very few non-leguminous species were infected. Parasitization under non-sterile conditions were found to include fewer species than with other methods (Carley, 1969). The question of the alternate host for survival of $\underline{A}_{\text {. euteiches }}$ is only partly answered and whether non-leguminous species help maintain, increase or rejuvenate propagules of this pathogen in the absence of peas needs more clarification. In addition, the mycelium of $\underline{A}$. euteiches was found very susceptible to lysis in non-sterile soil (Lockwood, 1960c), making this species a poor saprophyte under natural conditions. 


\section{Factors Affecting the Development of Disease Caused by $A$. euteiches}

\subsection{Inoculum Potential}

Most of the inoculations in laboratory and greenhouse experiments were made using zoospore suspensions which i) are easy to obtain free of other propagules, ii) can be easily counted and iii) can be applied as uniform inoculum (Papavizas and Ayers, 1974). The zoospore has been shown to be the infective unit, as oospores germinated only by zoosporangia when buried in special devices, next to roots of peas (Scharen, 1960). Infectivity of the zoospore of A $_{\text {. euteiches has been }}$ found to be quite high. Bhalla (1968) found that three motile or two non-motile zoospores per seedling could initiate infection in $50 \%$ pea seedlings. The $E D_{50}$ values were 16 and 282 motile zoospores in sterile and non-sterile soils, respectively. Concentrations as low as one zoospore/ml could produce oospores in excised root tips of certain hosts (Car1son, 1965).

For practical purposes, concentrations of more than $10^{4}$ zoospores/ $\mathrm{ml}$ are used to produce a consistently high level of disease. Johnson (1953) obtained maximum root rot of pea by applying $1.6 \times 10^{4}$ zoospores per square inch of soil. Lockwood and Ballard (1959) found that the application of $10 \mathrm{mI}$ of a $1.5 \times 10^{5}$ zoospores/m1 suspension per 10 inch row of seedling was needed. Under field conditions natural inoculum consists of oospores embedded in plant debris. The amount of debris containing oospores was positively correlated to DSI (Boosalis and Scharen, 1959). Inoculation of pea seedlings with artificially induced oospores (Beute and Lockwood, 1967) indicated no difference in infection patterns from those obtained by zoospore inoculations. 


\subsection{Temperature}

Aphanomyces root rot of peas has been found to develop at temperatures ranging from 15 to $30-35^{\circ} \mathrm{C}$ (Haensler, 1925; Jones and Drechsler, 1925; Jones and Linford, 1925). There is almost general agreement that no symptoms develop at temperatures below $14^{\circ} \mathrm{C}$ (Smith and Walker, 1941; Burke et al., 1969). Lockwood and Ballard (1959) found no significant differences between root rot indices at 20,24 and $28^{\circ} \mathrm{C}$. Oospore formation has also been influenced by temperature. Optimal temperature for oospores was around $25^{\circ} \mathrm{C}$ (Cho and King, 1963; Carley, 1969). The experiment carried out by Burke et al. (1969) showed an interesting aspect of the relation of temperature and infection. They found that disease incidence at $16^{\circ} \mathrm{C}$ was as high as that for 20,24 or $28^{\circ} \mathrm{C}$ but symptoms were delayed. If the plants infected at $16^{\circ} \mathrm{C}$ were washed and transferred to $28^{\circ} \mathrm{C}$, rapid development of symptoms occurred. In naturally infested soil, $\underline{\mathrm{A}}$. euteiches had a selective advantage at $16^{\circ} \mathrm{C}$ over other root rot fungi (Thielaviopsis basiola (Berk. and Br.) Ferraris and Fusarium sp.) which are less active at low temperatures.

\subsection{Age of Seedlings at Inoculation}

There seems to be agreement in the results obtained by different workers, that the age of the seedlings at inoculation affects the severity of Aphanomyces root rot of peas (Lockwood and Ballard, 1959; Lockwood, 1960) and sugar beets (Schneider, 1956). Inoculation with A. euteiches has generalily been performed on 7- to 8-day-old seedlings (Beute and Lockwood, 1967; Sundheim, 1972; Shehata et al., 1976). This would indicate that root rot of peas caused by $\underline{A}$. euteiches is particularly important at the seedling stage, although symptoms are often observed on mature plants due to the fact that the seedlings may sur- 
vive early infection.

\subsection{Soil Moisture}

Being a "water mold", $\underline{A}$. euteiches depends to a very great extent on high soil moisture to generate disease. Haensler (1927) found a minimum level of disease when soil was at $30 \%$ saturation. High soil moisture favored the development of the disease. Smith and Walker (1941) did not observe disease below $45 \%$ water holding capacity (WHC) while severe infection ( $72 \%$ plants infected) was obtained at $75 \%$ WHC. In the field, root rot was severe in wet seasons and low or negligible in dry years (Reinking, 1942; Reinking and Newha11, 1950)。

\section{Control of Aphanomyces Root Rot of Peas}

\subsection{Search for Tolerance to A. euteiches in Peas}

Little work was done in the $1920^{\prime}$ s and $30^{\prime}$ s on the screening for tolerance in peas to Aphanomyces root rot. The period was characterized by the identification (Jones and Drechsler, 1925), surveys of pea fields and studies of the biology of the fungus (Linford, 1927). However, some studies showed that certain pea cultivars were more tolerant than others (Haensler, 1925; Jones, 1926; Jones and Drechsler, 1925), but no immunity was reported.

Johnson (1953) compared the susceptibility of 22 pea introductions to A. euteiches. Twelve of these lines had greater tolerance to root rot than the commercial pea cultivars. Screenings for tolerance to $\underline{A}$. euteiches in the greenhouse required the development of inoculation techniques. Johnson (1953) used known zoospore concentrations to infect peas growing in sterilized soil. Lockwood and Ballard (1959) 
performed their tests with sterilized sand instead of soil. Another technique was developed by Haglund and King (1961) whereby peas were grown in vermiculite until 1-week-old. They were then removed, their roots washed and dipped for 24 hours in a $10^{5} \mathrm{zoosp} / \mathrm{ml}$ suspension and replanted in steam-treated soil in the greenhouse. A laboratory screening technique, based on the formation of oospores of $\underline{A}$. euteiches in excised root tips of peas, was developed and used (King and Cho, 1962; Cho and King, 1963; Carlson, 1965; Morrison et al., 1971). Root tips are usually cut and placed in petri dishes containing a zoospore suspension. After a period of incubation, the root tips are observed under a microscope and the number of oospores that have formed are counted. The area immediately behind the root cap was found to attract zoospores, while the root cap and the root hair zone did not (Cunningham and Hagedorn, 1962a). This region of the root tip was used for oospore counting (Morrison et al., 1971). More oospores formed in susceptible than in tolerant 1ines. A study on the penetration and infection of pea roots by zoospores of $\underline{A}$. euteiches (Cunningham and Hagedorn, 1962b) showed no differences between a susceptible and a tolerant line at 24 hours of incubation with regard to depth of penetration. The only "clear cut correlation was in the relative abundance and maturity of oogonia in the roots after periods of 59-65 hours". The "excised root tip technique" was not always precise, enough to detect "small amounts" of tolerance (Carlson, 1965) and is only suggested for preliminary screening of large numbers of pea introductions in the laboratory, followed by additional testing of the best lines under greenhouse or field conditions.

More recently, a new testing approach was used which utilized con- 
trolled environment chambers and greenhouses (Shehata et al., 1976)。 Seedlings were "submerged up to the hypocotyl area" in $100 \mathrm{ml}$ of a $1.5 \times 10^{5}$ zoospores/m1 suspension for 16 hours, then planted in pots containing autoclaved sand. The pots of sand were saturated and placed in plastic bags to maintain $100 \%$ relative humidity for 7 days. In the second phase, the inoculated seedlings were transplanted to a nonautoclaved soil-mix bed in the greenhouse and kept at $10-13^{\circ} \mathrm{C}$ (soil temperature) to favor "plant growth more than pathogen growth". The authors claim that this technique reduced resistance breakdown at an early stage of host development and gave a good separation between susceptible and tolerant lines. Attempts to incorporate tolerance into commercial types of peas were not always successful, and only a limited number of lines were released (King et al., 1957; Lockwood, 1960b; Shehata et al. , 1976).

Studies on the inheritance of tolerance of peas to $\underline{A}$. euteiches are rare. The only reported attempt revealed that tolerance was associated with undesirable dominant wild type alleles at three unlinked marker loci, i.e. Le (tall), A (colored flowers) and PL (yellow cotyledons). Substitution of the recessive alleles lead to a decrease in tolerance (Marx et al., 1972).

\subsection{Control of A. euteiches with Fungicides}

There is little information on control of $\underline{A}$. euteiches by fungicide seed treatment. Most of the work reported employed soil treatments. Chloronitxopropane (Lanstan) was effective as an in-furrow application (Haglund, 1968), but was not recommended because it was found to be lacrymatory and highly toxic (Papavizas and Ayers, 1974). Some fumigants have also been found effective in greenhouse tests and in some 
cases in the field. According to Papavizas and Ayers (1974), these fungicides have not been adequately tested in the field.

Among the non-volatile fungicides, Dexon appeared to be effective, but not economically feasible (Mitchell and Hagedorn, 1971). This fungicide has been found to persist in soil for long periods of time and to reduce propagules of $\underline{A}$. euteiches. Approximately $1 \mu g$ of residual Dexon per gram of soil was needed to inhibit zoospore formation. An amount of $301 \mathrm{~b} /$ acre would be required to meet this residual quantity (1 $\mu \mathrm{g} / \mathrm{g}$ soil).

\subsection{Control of A. euteiches by Herbicide Treatments}

Effects of herbicides on disease incidence under field conditions have been recently reviewed by Altman and Campbell (1977). Some negative effects of herbicide applications have been observed. The application of PCA and pebulate to soil in greenhouse experiments resulted in increased damping-off of sugar beet by Rhizoctonia solani (Altman and Ross, 1967; Altman, 1972). Similar results were observed by Antonopoulos (1969). Trifluralin and dinoseb also increased disease due to $\underline{R}$. solani on snapbean (Roming and Sasser, 1972) and studies in vitro showed that these herbicides reduced the amount of phytoalexin in bean plants, thus altering the biochemical defences of the host. Trifluralin and dinitroaniline herbicides, however, have been found to reduce pea root rot in the field. Carlson and Hopen (1971) found that plots treated with trifluralin (Treflan) for weed control had less disease and similar effects were reported by other workers (Harvey et a1., 1975; Grau and Reiling, 1977; Sacher et al., 1978). Grau (1977) showed that these herbicides had a direct effect on the pathogen in vitro and in vivo. The mechanism of root rot suppression was first 
explained by Teasdale et a1 (1979). These authors demonstrated that suppression was not due to the effect of the herbicide on the plant but to direct effect on the pathogen, as shown by Grau (1977). The most sensitive stage in the life cycle of $\underline{A}$. euteiches was found to be the production of motile zoospores which could be completely inhibited by $0.01 \mathrm{ppm}$ of all dinitroaniline herbicides tested. This was confirmed by a more recent study (Jacobsen and Hopen, 1981). Dinoseb was found effective in pea root rot control. In in vitro studies, trifluralin was found to enhance oospore production by the pathogen, while Dinoseb did not (Jacobsen and Hopen, 1981). It is not known whether this enhancement occurs under field conditions. 
RE SULTS OF RESEARCH

1. Etiology of Seedling B1ight and Root Rot of Faba Bean (Vicia faba) in Manitoba

ABSTRACT

An Aphanomyces sp., Rhizoctonia solani Kuehn and a Fusarium sp. were associated with seedling blight and root rot of faba bean (Vicia faba L.) in Manitoba. Pathogenicity tests indicated that the Aphanomyces sp. was the main pathogen at the Campus farm of the University of Manitoba. In addition to faba bean, the Aphanomyces sp. infected lentils (Lens culinaris L.), Lathyrus sp., garden peas (Pisum

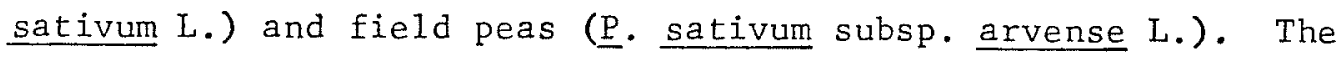
Aphanomyces sp. from faba bean was morphologically and culturally similar to Aphanomyces euteiches Drechs. It would appear that this is the first report on the association of A. euteiches with root rot of faba bean and lentils in the field.

The 10 isolates of $\underline{R}$. solani from faba bean, pea and rapeseed tested, varied in pathogenicity to faba bean. The pathogenic isolates of $\underline{R}$. solani caused damping-off on faba bean plants, except for one isolate from Eastern Manitoba. The latter caused a soft rot of the stem and roots and had more pathogenie capabilities than any of the other isolates.

The Fusarium sp. recovered from mature faba bean plants in a commercial field in Eastern Manitoba caused severe root rot when inoculated on faba bean and pea seedlings. This fungus was tentatively identified as Fusarium avenaceum (Fr.) Sacc. 


\section{INTRODUCTION}

Faba beans (Vicia faba L.) have been grown commercially on a limited acreage in Manitoba for the last decade. In 1980, the area under cultivation was estimated to be 8,800 hectares (Anonymous, 1981). The crop was found to be well adapted to the moister cereal growing areas in Western Canada and is grown as a high protein crop for animal feed and export (Evans et al., 1972).

Very little is known about pathogens that may cause root diseases on faba beans in Manitoba. Early surveys indicated that Fusarium spp.,

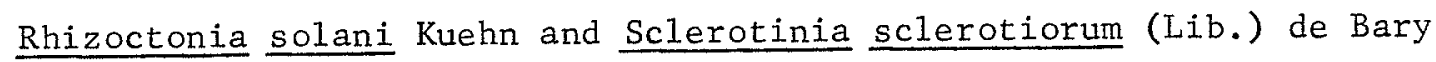
were associated with root rot of faba beans in the province (Platford and Bernier, 1973) and that root diseases were generally of low incidence. However, severe root rot and seedling blight have been observed in experimental field plots at the University of Manitoba (U of M) since 1978 . Young seedlings were often blighted and older plants were stunted and yellow. The root systems of virtually all plants in the disease nursery were blackened and plants of more susceptible cultivars were completely destroyed. Root rot was also found to be common and severe in some conmercial fields of faba bean in Eastern Manitoba in 1978 and 1979 (G. Platford, personal communication).

Studies were initiated to determine the etiology of seedling blight and root rot of this crop in Manitoba. This paper reports on the isolation, identification and pathogenicity of the organisms involved and compares the symptoms induced in the greenhouse by the fungi isolated, with those of field-infected plants. 
MATERIALS AND METHODS

\section{Fungal Isolation}

Infected seedlings uprooted during field surveys were brought to the laboratory in plastic bags and stored in a refrigerator at $5^{\circ} \mathrm{C}$ when not used immediately. The roots were thoroughly washed by hand under running tap water, cut into 5-10 mm pieces and surface sterilized in $1 \%$ sodium hypoch1orite for 30-90 seconds. Pieces of roots of each seedling were rinsed in sterile distilled water, blotted dry on sterile filter paper and plated on $2 \%$ water agar (WA), potato dextrose agar (PDA) and acidified PDA (APDA). Other media were used to isolate specific pathogens, namely Nash and Snyder's medium (1962) for Fusarium spp. and Ko and Hora's medium (1971) for $\underline{\mathrm{R}}$. solani. When specific media were used, the roots were usually not surface sterilized prior to planiting. The two selective media are described in Appendices 1 and 2.

Inoculum Production

Isolates of all Fusarium spp. were cultured in potato dextrose broth in $100 \mathrm{ml}$ flasks and incubated at room temperature (ca $22^{\circ} \mathrm{C}$ ) on a shaker for 4 days. The content of the flasks was filtered through cheesecloth to remove the mycelium. The spores were washed, suspended and adjusted to $10^{6}$ conidia/ml with distilled water. Spore concentrations were determined with a haemocytometer.

Zoospores of the Aphanomyces sp. were produced by the method of Llanos and Lockwood (1960) with a slight modification. Water agar plates 
were used instead of flasks, thereby requiring no aeration to enhance sporulation. The zoospores suspensions were adjusted to $10^{5}$ zoospores/mI $(z s p / m 1)$ with distilled water (Appendix 3).

Mycelium of all isolates of $\underline{\mathrm{R}}$. Solani and the Aphanomyces sp. was produced by culturing on PDA plates and incubating for 1 week at room temperature.

\section{Pathogenicity Tests}

Seeds of the cultivars used were surface sterilized in $2.5 \%$ sodium hypochlorite for $5 \mathrm{~min}$, rinsed twice in sterile water and planted in a standard steamed soil:sand:peat $\operatorname{mix}(1: 1: 1 \mathrm{v} / \mathrm{v})$, or in vermiculite if the seedlings were to be uprooted for inoculation. Plastic flats (52 $\mathrm{cm} \times 26 \mathrm{~cm} \times 5.5 \mathrm{~cm}$ ) were used in a11 experiments。

For isolates of the Fusarium spp., 7-day-old seedlings of the cultivars Ackerperle (faba bean), Trapper (field pea) and Maple Presto (soybean) were uprooted, the roots washed in tap water, dipped in a $10^{6}$ spores/ml suspension for $10 \mathrm{~min}$ and replanted in the soil mix. At least 40 plants were inoculated with each isolate.

For the Aphanomyces sp., $10 \mathrm{ml}$ of a $10^{5} \mathrm{zsp} / \mathrm{ml}$ suspension were pipetted onto each row (10 to 12 seedlings) close to the stems of 7-dayold seedlings. Inoculation with mycelium was performed on seedlings grown in vermiculite. A $3 \mathrm{~mm}$ disc of PDA with mycelium was applied against the tap root of each seedling, $1 \mathrm{~cm}$ below the seed and covered.

For $\underline{R}$. Solani, a $5 \mathrm{~mm}$ PDA disc with mycelium was placed $2 \mathrm{~cm}$ deep in the soil near the stem of each seedling and covered with soil.

\section{Evaluation of Selected Cultivars in Naturally Infested Soil}

Several cultivars of leguminous and non-leguminous species were 
evaluated at the $U$ of $M$ in a field with a history of seedling blight and root rot (Table 2). Each cultivar was planted in a single row plot, $3 \mathrm{~m}$ long and replicated three times.

\section{Disease Rating}

Faba bean plants were scored for disease on a $0-4$ scale adapted from the scale described for peas by Smith and Walker (1941), where $0=$ healthy white roots, 1 = cortical black discoloration of tap root, 2 = black discoloration on the tap and lateral roots and epicotyl but no decay, 3 = black areas soft, epicotyls and roots water soaked and $4=$ tissues disintegrated. Dead plants were rated 4. A disease severity index (DSI) was computed as follows (Sherwood and Hagedorn, 1958):

$$
\operatorname{DSI}(\%)=\left(\sum_{i=0}^{4} n i \mathrm{Xi} / \sum_{i=0}^{4} n i\right) \times 25
$$

where $\mathrm{Xi}=$ class value $(0,1,2,3,4)$ and $\mathrm{ni}=$ number of plants in class Xi.

For microscopic observation, blackened infected faba bean tissue was dipped in $1 \%$ sodium hypochlorite solution until cleared (15 to $20 \mathrm{mn}$ ), rinsed in water and mounted on slides after staining with aniline or trypan blue in lactophenol. 


\section{RESULTS}

Seedling blight and root rot were generally severe in 1979, 1980 and 1981 in the disease nursery and some other fields at the Campus farm ( $U$ of $M$ ). The fungi isolated during the three seasons are listed in Table 1, along with their frequency of isolation.

In 1979 , only Fusarium spp. and $\underline{\mathrm{R}}$. Solani were isolated from faba bean seedlings sampled in the middle and the end of the season. In 1980 and 1981, an Aphanomyces sp. was isolated along with the two previous fungi. Other fungi, bacteria and saprophytic nematodes were commonly recovered during the three seasons. Microscopic observations of the roots of almost every plant sampled in 1980 and 1981 from the disease nursery revealed the presence of numerous oospores similar to those of Aphanomyces (Fig. 1). The increase in percentage of recovery of the Aphanomyces sp. in 1980 and 1981 is attributed to the use of newly infected seedlings for fungal isolation and also to the inclusion of several susceptible faba bean and pea cultivars in the tests (Table 2). R. Solani and Fusarium spp. were isolated from decayed roots of faba bean as in 1979 .

The Aphanomyces sp. was isolated more frequently on $2 \%$ WA and PDA, but it was difficult to transfer mycelium free of bacteria from PDA cultures. The Fusarium spp. and $\underline{\mathrm{R}}$. solani were isolated on their respective selective media as well as on PDA, APDA and WA. Bacterial contamination was reduced if the roots of newly infected faba bean seedlings were washed by hand and left overnight under running tap water. 
TABLE 1. Fungal species isolated from diseased faba bean seedlings in experimental plots at the University of Manitoba.

\begin{tabular}{lccc}
\hline & \multicolumn{3}{c}{ of Seedlings } \\
\cline { 2 - 4 } Fungal species & 1979 & 1980 & 1981 \\
\hline Aphanomyces sp. & 0 & 40 & 72 \\
Fusarium spp. & 75 & 72 & 55 \\
$\frac{\text { Rhizoctonia }}{\text { solani }}$ & 6.2 & 20 & 35 \\
Other fungi & & 10 & 10 \\
\hline
\end{tabular}

Fungal isolations were made from 80 plants in 1979 and from approximately 200 plants in both 1980 and 1981.

+ Values represent the \% of seedlings from which a given fungus was isolated. More than one fungal species may be isolated from the same seedling.

H These include Alteraria spp., Cylindrocarpon spp., Rhizopus spp., Aspergillus spp. and a few non-identified fungi. 


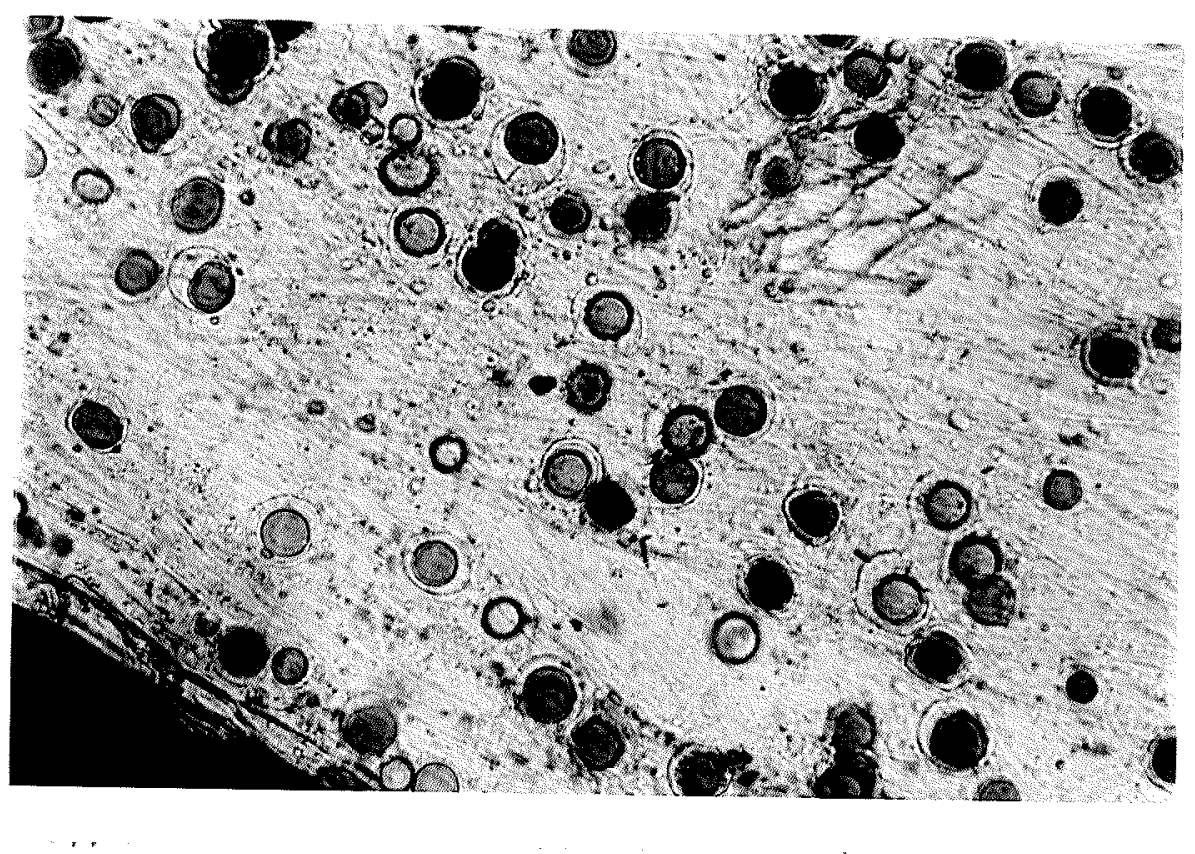

Figure 1. Oospores of Aphanomyces sp. in an infected root of the faba bean cultivar PI 222128. 
TABLE 2. Response of leguminous and non-leguminous species and cultivars to Aphanomyces root rot in a naturally infested field at the University of Manitoba.

\begin{tabular}{|c|c|c|c|}
\hline & Infection ${ }^{*}$ & Oospores ${ }^{\star \star}$ & $\begin{array}{c}\text { Isolates of } \\
\text { Aphanomyces } \mathrm{sp} \text {. }\end{array}$ \\
\hline \multicolumn{4}{|l|}{ Peas (garden) } \\
\hline Little Progress & + & P & I \\
\hline Thomas Laxton & + & $P$ & I \\
\hline Homes teader & + & $\mathbf{P}$ & I \\
\hline Little Marvel & ++ & $P$ & I \\
\hline Green Arrow & + & $P$ & I \\
\hline \multicolumn{4}{|l|}{ Peas (field) } \\
\hline Trapper & + & $\mathrm{P}$ & I \\
\hline Century & + & P & I \\
\hline Triumph & + & $\mathrm{P}$ & I \\
\hline Tara & + & $P$ & I \\
\hline \multicolumn{4}{|l|}{ Faba bean } \\
\hline Ackerperle & + & $\mathrm{P}$ & I \\
\hline PI 222128 & + & $P$ & I \\
\hline Triple White & $+H$ & $P$ & I \\
\hline Mikko & ++ & $P$ & I \\
\hline Erfordia & + & $P$ & I \\
\hline Herz Freya & + & $\mathrm{P}$ & I \\
\hline Diana & + & $\mathrm{P}$ & I \\
\hline Sugar beet & - & A & NI \\
\hline \multicolumn{4}{|l|}{ Lentils } \\
\hline White lentil & + & P & I \\
\hline Dark lentil & + & $\mathrm{P}$ & I \\
\hline \multicolumn{4}{|l|}{ Alfalfa } \\
\hline Pioneer & - & A & NI \\
\hline \multicolumn{4}{|l|}{ Soybean } \\
\hline Mc All & - & A & NI \\
\hline Maple Amber & - & A & NI \\
\hline Maple Presto & - & A & $\mathrm{NI}$ \\
\hline Lathyrus sp. & + & $\mathrm{p}$ & I \\
\hline \multicolumn{4}{|l|}{ Snap beans } \\
\hline Black beans & - & $\dot{A}$ & $\mathrm{NI}$ \\
\hline Sea Fearer & - & A & NI \\
\hline Mung beans & - & A & $\mathrm{NI}$ \\
\hline \multicolumn{4}{|l|}{ Rapeseed } \\
\hline Candle & - & A & NI \\
\hline Regent & - & A & NI \\
\hline Potato & & A. & NI \\
\hline Flax & - & A & NI \\
\hline
\end{tabular}

${ }^{*},+,++,++=$ respectively: no symptoms, sligit, moderate and severe infections.

** Microscopic observations of oospores were done on at least 10 plants/cultivar or species; $\mathrm{P}=$ Present; $\mathrm{A}=$ Absent.

$I=$ Isolated; NI = Not isolated 
Recovery of Aphanomyces sp. was improved by this washing schedule.

R. Solani and a Fusarium sp. were isolated from four mature faba bean plants with severe root rot in 1979. The plants were from a commercial field in Eastern Manitoba and were received through the Manitoba Department of Agriculture. In 1980, a survey of some commercial fields of faba beans in Eastern Manitoba indicated that root rot incidence was low $(2-3 \%)$. Fungal isolations were made from 50 diseased seedlings and yielded $\underline{\text { R. Solani }}$ (100\% of seedlings) and an isolate of the Fusarium sp. recovered in 1979 and tentatively identified as Fusarium avenaceum (Fr.) Sacc. according to the description of Booth (1977).

\section{Evaluation of Selected Cultivars in Naturally Infested Field}

Al1 faba bean, lentil and pea cultivars, as well as Lathyrus sp. planted in the disease nursery at the $U$ of $M$ were infected by the Aphanomyces sp. Parasitization was confirmed by the presence of oospores typical of the genus (Fig. 1) and also by the isolation of the fungus in pure culture (Table 2). Oospores of Aphanomyces were not found in roots of alfalfa, snap beans, rapeseed, potato, flax, sugar beet, volunteer wheat and pigweed. $\underline{R}$. Solani was isolated from snap bean plants early in the season and later from peas, faba beans, potato and Lathyrus sp., while Fusarium spp. were commonly isolated from infected roots and stems of all cultivars used for fungal isolation. Damage due to $\underline{R}$. solani on snap beans was not important because the seedlings from which the fungus was isolated appeared healthy and the lesions were superficial on the below-ground part of the stem. Several seedlings from faba bean and pea cultivars infected by the Aphanomyces sp. were severely affected, therefore the contribution of $\underline{\mathrm{R}}$. Solani and Fusarium spp. to the disease 
development could not be assessed.

\section{Pathogenicity Tests}

Twelve isolates of the Fusarium spp. isolated from faba bean in 1979 at the $U$ of $M$ and four isolates from Eastern Manitoba tested along with F. graminearum, $\underline{F}$. oxysporum pisi race 1 and $\underline{F}$. solani (supplied by Dr. Reid, Department of Botany, $U$ of $M$ ) were found to be non-pathogenic to Ackerperle, Trapper and Maple Presto.

The Fusarium tentatively identified as $\underline{F}$. avenaceum recovered in 1979 caused severe root rot on faba bean and peas but not on soybean. Initially, it induced black lesions of the lateral roots and later on the tap root of faba bean with the whole seedling eventually collapsing. Symptoms induced by this species of Fusarium could not be ompared with field symptoms because the fungus was isolated from mature plants.

The identification of $\underline{R}$. Solani was based solely on the asexual stage. All isolates tested for pathogenicity were found to be multinucleate when stained by the method described by Burpee et al. (1978) (Appendix 4). In addition to their nuclear condition, the isolates had all the characteristics attributed to $\underline{R}$. $\underline{\text { solani }}$ Kuehn by Parmeter and Whitn ey (1970)。

Eight isolates of $R$. solani recovered from infected faba bean plants as well as one isolate each from peas and rapeseed were tested for pathogenicity (Table 3). Isolates 3, 12 and 13 from the disease nursery, as well as isolates 1 and 20, respectively from Eastern Manitoba and the greenhouse ( $U$ of $M$ ) were pathogenic to faba beans on the basis of their ability to infect the stem of the two cultivars tested. Isolate 3 was the most virulent isolate on both pea cultivars. Isolates 1,12 and 13 were mildly pathogenic to Trapper, but not to Century (Table 3 ). 
TABLE 3. Stem and seed infection of two faba bean and two field pea cultivars inoculated with 10 isolates from Rhizoctonia solani.

\begin{tabular}{|c|c|c|c|c|c|c|c|c|c|c|}
\hline \multirow{3}{*}{$\begin{array}{c}\text { Isolate } \\
\text { 非 }\end{array}$} & \multirow{3}{*}{ Origin } & \multirow{3}{*}{ Host } & \multicolumn{4}{|c|}{ Faba Bean } & \multicolumn{4}{|c|}{ Field Peas } \\
\hline & & & \multicolumn{2}{|c|}{ Ackerperle } & \multicolumn{2}{|c|}{ PI 222128} & \multicolumn{2}{|c|}{ Century } & \multicolumn{2}{|c|}{ Trapper } \\
\hline & & & $\begin{array}{l}\text { Stem } \\
(\%)\end{array}$ & $\begin{array}{l}\text { Seed }^{* \hbar} \\
(\%)\end{array}$ & Stem & Seed & Stem & Seed & Stem & Seed \\
\hline 1 & E. Man. ${ }^{+}$ & $\mathrm{FB}+i$ & 76.0 & 72.0 & 96.7 & 80.6 & 4.2 & 79.2 & 18.5 & 62.9 \\
\hline 2 & $\mathrm{U}$ of $\mathrm{M} 18$ & Pea & 62.5 & 37.5 & 32.3 & 38.2 & 57.1 & 91.4 & 44.4 & 92.5 \\
\hline 5 & $\mathrm{U}$ of $\mathrm{M} 18^{++}$ & $\mathrm{FB}$ & 0.0 & 3.6 & 2.8 & 2.8 & 0.0 & 40.0 & 0.0 & 38.8 \\
\hline 7 & $\mathrm{U}$ of $\mathrm{M} 5$ & $\mathrm{FB}$ & 0.0 & 7.4 & 0.0 & 0.0 & 3.1 & 56.7 & 0.0 & 32.1 \\
\hline 8 & $\mathrm{U}$ of $\mathrm{M} 5$ & $\mathrm{FB}$ & 3.3 & 6.6 & 0.0 & 6.1 & 0.0 & 45.7 & 0.0 & 20.7 \\
\hline 10 & Aboretum & Rapeseed & 0.0 & 19.4 & 0.0 & 0.0 & 3.2 & 54.8 & 0.0 & 55.2 \\
\hline 12 & $\mathrm{U}$ of $\mathrm{M} 18$ & $\mathrm{FB}$ & 44.0 & 60.0 & 15.6 & 68.7 & 8.8 & 67.6 & 24.2 & 100.0 \\
\hline 13 & $U$ of $M 18$ & $\mathrm{FB}$ & 40.0 & 88.0 & 0.0 & 65.6 & 12.1 & 100.0 & 44.1 & 94.1 \\
\hline 14 & E. Man. & $\mathrm{FB}$ & 4.8 & 19.0 & 0.0 & 0.0 & 0.0 & 63.9 & .3 .4 & 31.0 \\
\hline 20 & Greenhouse & $\mathrm{FB}$ & 43.3 & 76.7 & 16.2 & 77.4 & 21.9 & 93.8 & 23.5 & 97.1 \\
\hline \multicolumn{3}{|c|}{ Noninoculated } & 0.0 & 5.5 & 0.0 & 10.3 & 0.0 & 5.8 & 0.0 & 6.6 \\
\hline
\end{tabular}

+ E. Man. = Eastern Manitoba, commercial fields.

$+\mathrm{FB}=$ faba bean.

H+ U of M 18 = University of Manitoba, Campus farm, number indicates the field number.

* of plants with lesions extending at least $3 / 4$ of the stem.

$* \%$ of seeds decayed, after germination. Data represent averages on 30-36 
The pathogenic isolates of $\underline{R}$. solani induced damping-off with the exception of isolate $k_{1} 1$ which produced a black soft rot of stems and part of the roots of faba beans (Fig. 2). Isolate 非 produced sclerotia on artificial media 4-5 days earlier than the other isolates and had a longer incubation period when inoculated on faba bean. Symptoms induced by isolate 非 were visible 10 days after inoculation, whereas damping-off by the other isolates occurred 4-5 days after inoculation of 7-day-old faba bean seedlings.

Isolates $5,7,8,10$ and 14 were not pathogenic on either faba bean or peas, although they caused some seed rot on peas, but not on faba bean (Table 3).

Plants inoculated with zoospores or mycelium of the Aphanomyces sp. were all infected and showed above ground symptoms approximately 1 week after inoculation (Fig. 3). The entire root system and the above ground stem turned black in response to fungal invasion. The discoloration was at first cortical but affected all the vascular system as disease progressed. A decay of roots and epicotyls followed and seedlings collapsed.

The extent of the black discoloration was measured for the plants inoculated with mycelium and was found to range from $3-8 \mathrm{~cm}$ for the roots and from $1.8-4.4 \mathrm{~cm}$ for the stems of different cultivars (Table 4). Numerous oospores were observed in discolored tissues of each cultivar.

of the fungi isolated from the $U$ of $M$ disease nursery, only Aphanomyces sp. reproduced the symptoms observed on field infected seedlings (Fig. 3a, b, c).

The Aphanomyces sp. was recognized by its typical arachnoid type of growth on artificial media. Before evacuation, the zoospores were arranged 
Figure 2. Symptoms induced by Rhizoctonia solani in plants of Vicia faba in the greenhouse. a) faba bean seedlings 6 days after inoculation with $R$. solani, isolate 非 1 . b) seedlings in fig. 2a, $\overline{3}$ days later, c) stem and some root discoloration induced by isolate \#1, d) damage to a seedling by a damping-off isolate of $\underline{R}$. solani. 


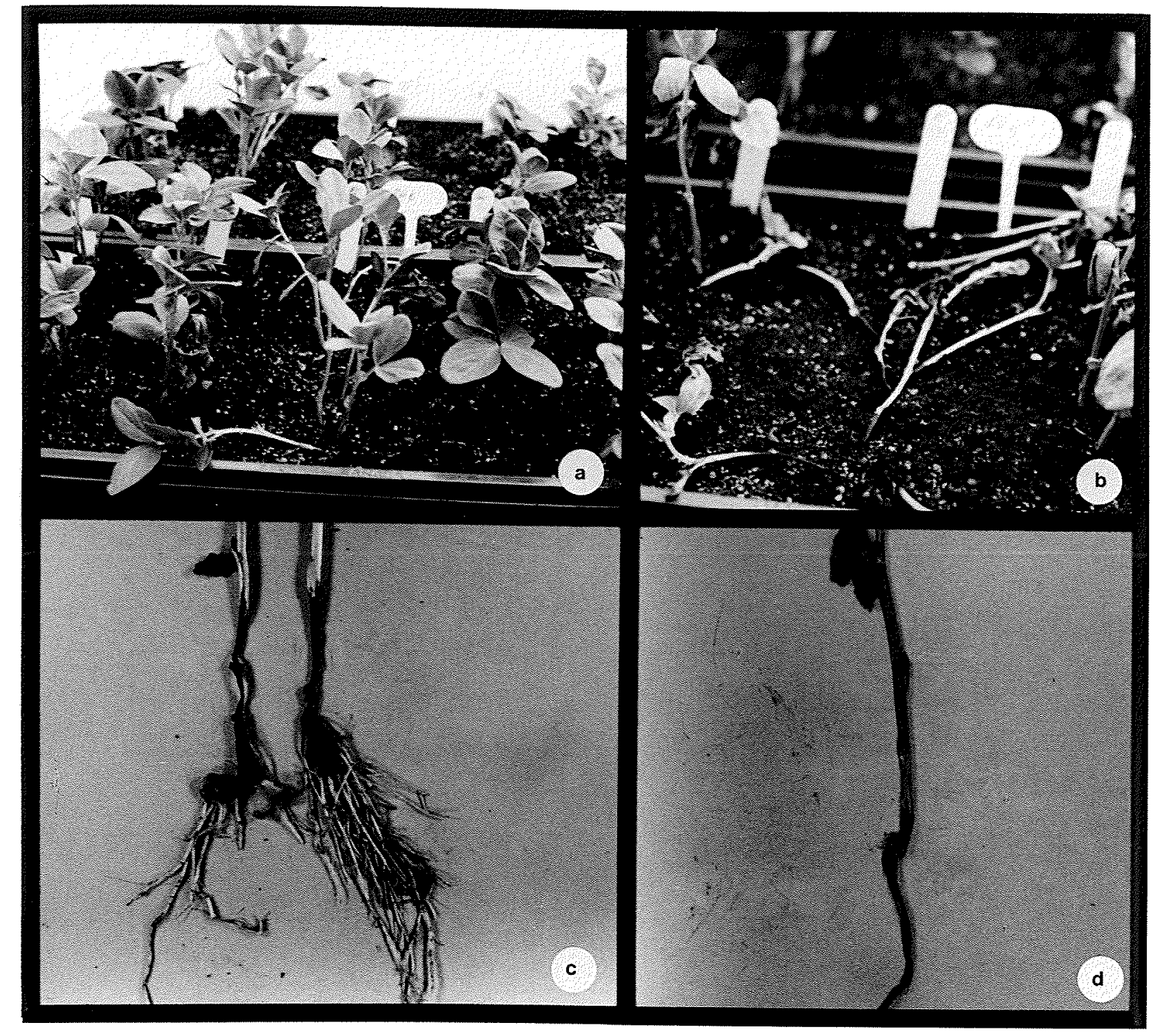


Figure 3. Symptoms induced by Aphanomyces euteiches in plants of Vicia faba in the field and in the greenhouse. a) seedling blight observed in the field. Arrow indicates a dead seedling. b) and c) decayed and discolored roots of faba bean in the field, d) and e) greenhouse inoculated faba bean seedling. Note black discoloration of roots and stems. 


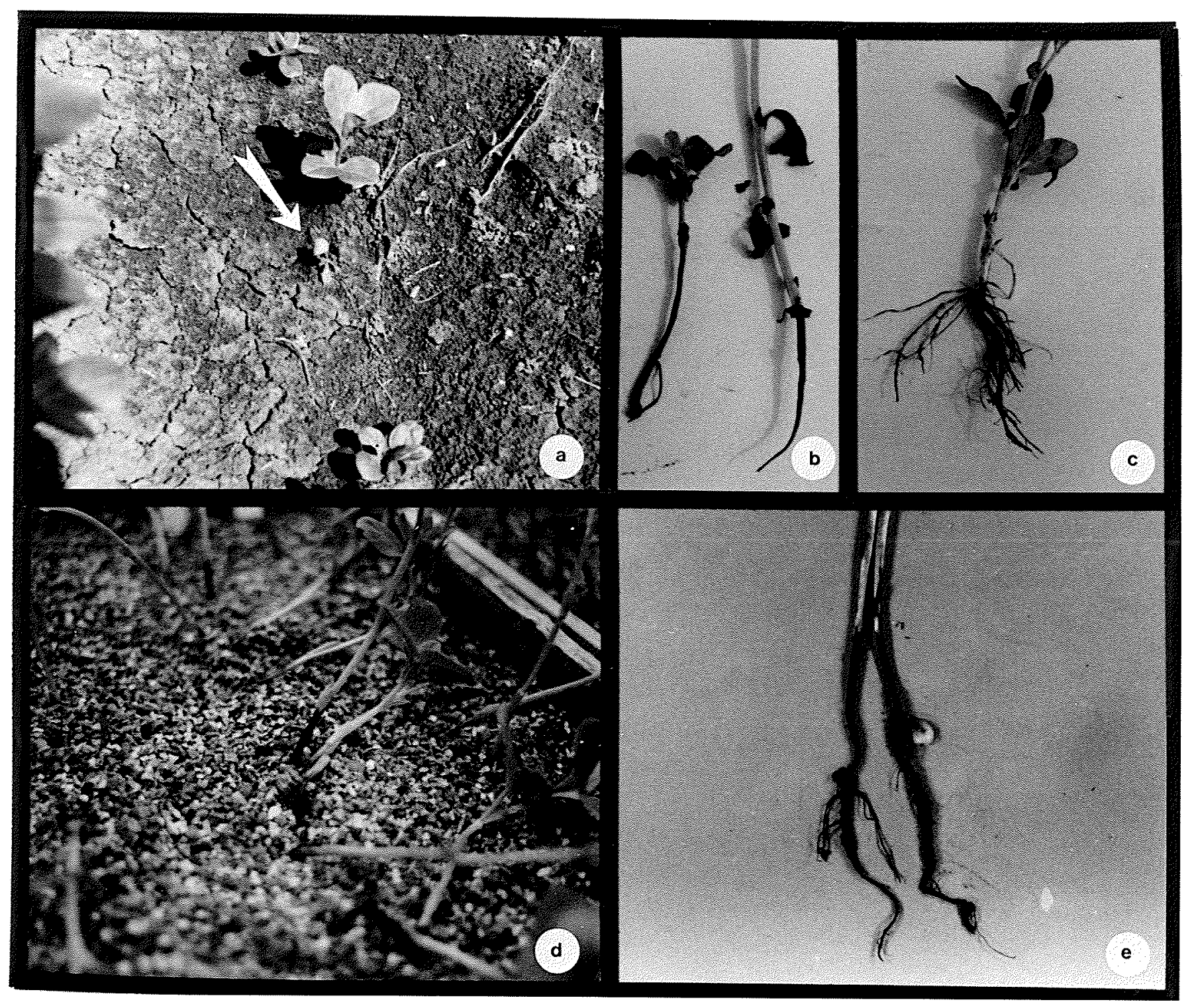




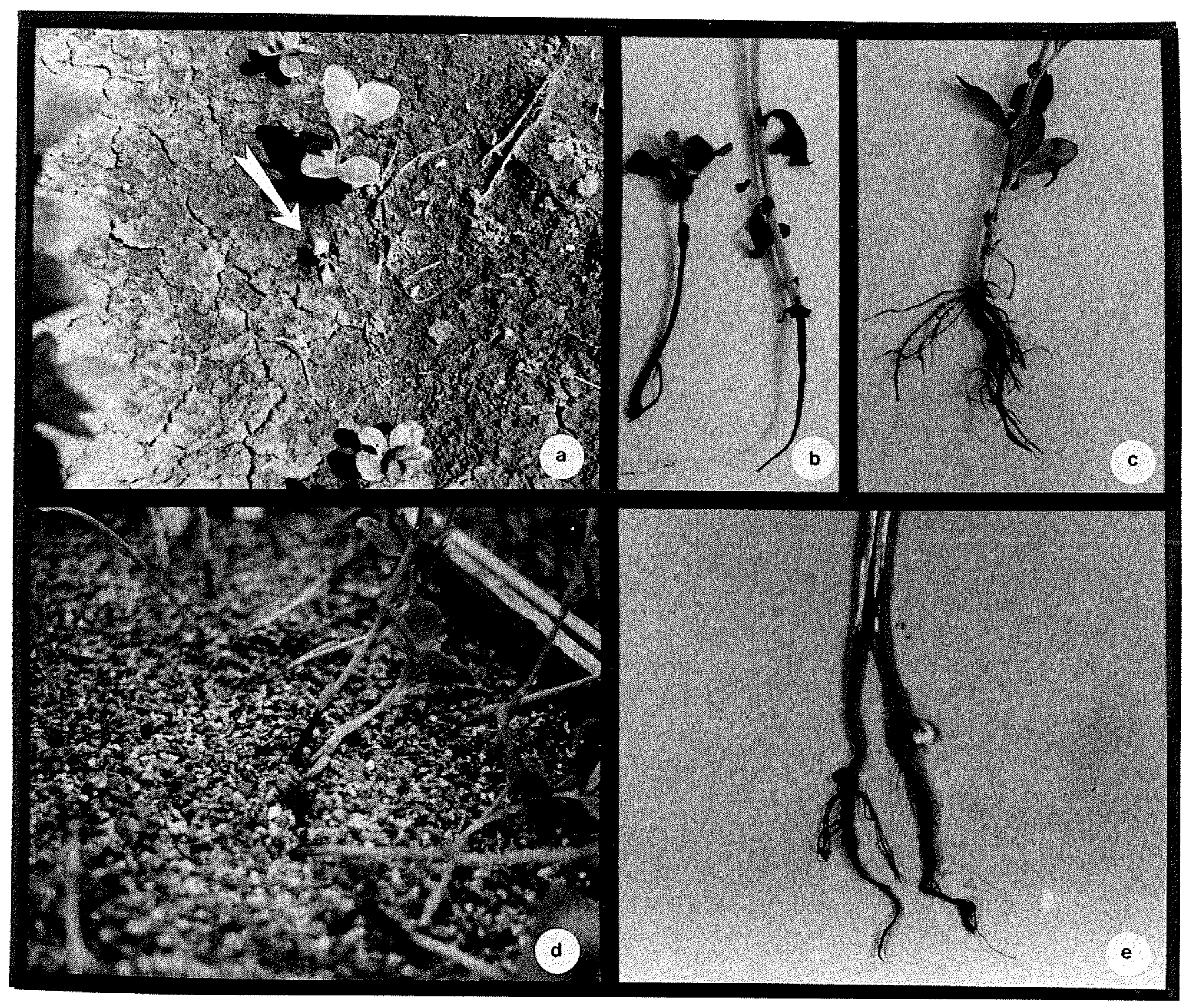


TABLE 4. Response of three faba bean and one field pea cultivars to

inoculation with mycelium of an Aphanomyces sp. from faba bean.

\begin{tabular}{|c|c|c|c|c|c|}
\hline & $\begin{array}{l}\text { Plants } \\
\text { inoculated } \\
\text { (no.) }\end{array}$ & $\begin{array}{l}\text { Plants } \\
\text { infected } \\
\quad(\text { no. })\end{array}$ & $\begin{array}{l}\text { DSI } \\
(\%)\end{array}$ & $\begin{array}{c}\text { Root } \\
\text { discoloration } \\
(\mathrm{cm})\end{array}$ & $\begin{array}{l}\text { Stem } \\
\text { discoloration } \\
(\mathrm{cm})\end{array}$ \\
\hline \multicolumn{6}{|l|}{ Faba bean } \\
\hline PI 222128 & 20 & 20 & 92.5 & 8.0 & 4.4 \\
\hline Diana & 19 & 19 & 92.1 & 7.2 & 4.0 \\
\hline Ackerperle & 20 & 20 & 87.5 & 5.2 & 2.1 \\
\hline \multicolumn{6}{|l|}{ Field pea } \\
\hline Trapper & 15 & 15 & 65.3 & 3.0 & 1.8 \\
\hline
\end{tabular}

* The extent of discoloration was measured from the seed downward (root) and upward (stem). Values represent means from at least 15 plants/cultivar. 
Figure 4. Vegetative and sexual structures of Aphanomyces euteiches isolated from Vicia faba. a) zoospores typically arranged in a single row. b) a cluster of primary nonmotile zoospores. c) an oogonium and antheridium before oospore formation. d) a fully mature oospore. 


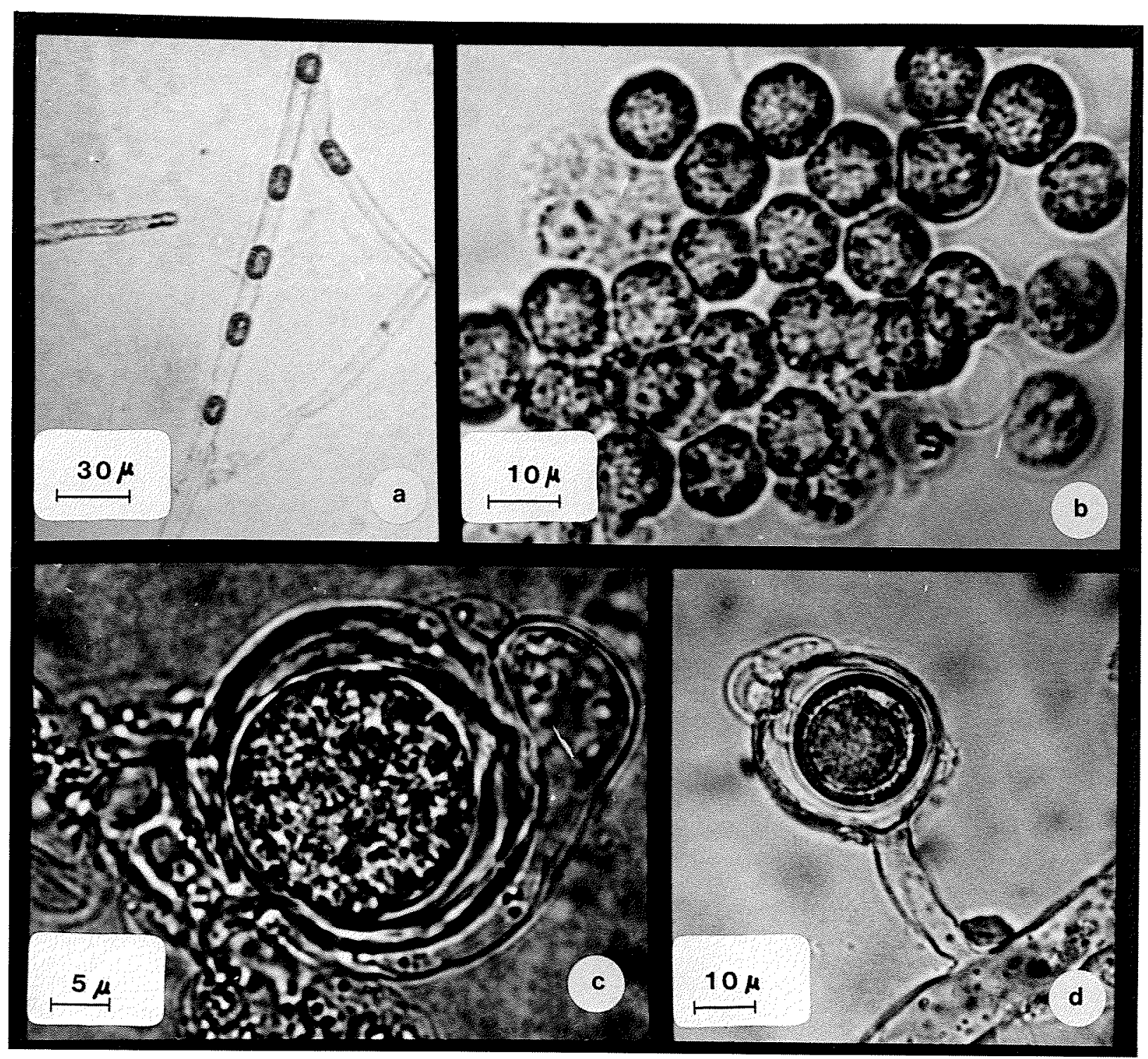


in a single row within an undifferentiated zoosporangium (Fig. 4a). The primary zoospores rounded off and clustered at the mouth of the evacuation tube (Fig. 4b), then gave rise to laterally biflagellate zoospores. Oogonia were terminal on short lateral branches and were delimited from the stalk on which they were formed by a septum (Fig. $4 \mathrm{c}$, d) with the oogonium containing a single thick-walled oospore (Fig. 4d). The measurements of the sexual structures and other characteristics, along with the pathogenicity to peas and other leguminous plants, place the isolates recovered from faba bean at the $U$ of $M$ closest to A. euteiches Drechs., the pathogen of the common root rot of peas (Jones and Drechsler, 1925). The identification was confirmed by the Biosystematics Research Institute, Ottawa (非 B413). 
DISCUSSION

Seedling blight and root rot of faba bean have been found in this study to be caused by $\underline{A}$. euteiches at the $U$ of $M$ Campus farm and by $\underline{R}$. solani in commercial fields in Eastern Manitoba. The Fusarium avenaceum (?) isolated from mature plants with severe root rot in Eastern Manitoba was found to be pathogenic to faba bean as well as to peas. However, attempts to evaluate the importance of this fungus in the field in 1980 failed.

The increased frequency of recovery of $\underline{A}$. euteiches from infected plants of several legumes in the seedling stage at the $U$ of $M$ experimental field plots suggests that disease was primarily due to $\underline{A}$. euteiches and that $\underline{R}$. solani and Fusarium spp. acted as secondary invaders. A similar situation was reported by Salt and Hornby (1971a), who isolated Fusarium and Pythium spp., ‥ solani and Phytophthora megasperma from infected faba bean plants. The latter was the least frequently isolated, but was found to be the only fungus able to cause root rot and wilt in greenhouse experiments. It was thought that $\underline{p}$. megasperma was possibly replaced by the other fungi once the symptoms were advanced (Salt and Hornby, 1971b).

All damping-off isolates of $\underline{R}$. Solani tested in this study induced discrete brown or black lesions on the stems of the seedlings at ground leve1, whereas $\underline{\mathrm{R}}$. solani isolate $\# 1$ and $\underline{\mathrm{A}}$. euteiches induced a soft, black rot of the entire root system and part of the stems. McEwen et al. (1981) also recognized two types of symptoms: i) a wet root rot 
caused by oomycetous fungi and ii) a dry rot of the root cortex and stem bases associated with Fusarium spp., $\underline{\mathrm{R}}$. $\underline{\text { solani }}$ and other Fungi Imperfecti. The association of several fungi in root diseases, in addition to the black discoloration of faba bean roots in response to any injury, make it difficult to visually characterize the symptoms caused by different pathogens in the field. Isolation of the organisms in pure cultures and tests for pathogenicity, although time-consuming, remain the only reliable method of ascertaining the cause of root diseases of faba bean.

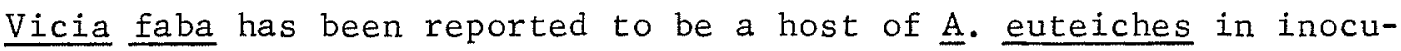
lation experiments with pure cultures of the fungus (Carlson, 1965; Ridings and Zettler, 1973), but not in non-sterile soil (Haensler, 1926). This would appear to be the first report on the association of A. euteiches with root rot of faba bean in the field. This pathogen has been found to cause pea root rot in Eastern Canada, but was apparently an unimportant pathogen in Ontario (Conners, 1967). However, in many pea growing areas of the USA, this pathogen is still a limiting factor for pea cultivation (Papavizas and Ayers, 1974).

The isolates of $\underline{\mathrm{R}}$ solani tested in this study were more invasive to faba bean stems than to those of peas. The latter crop appeared to be more susceptible to seed rot.

The evaluation of several cultivars in the disease nursery ( $U$ of M) revealed the existence of variability in tolerance to Aphanomyces root rot among, as well as within, the leguminous species tested. Lentils (Lens culinaris L.) appeared to be very susceptible to A. euteiches. Root rot of lentils does not appear to have been previously found associated with $\underline{A}$. euteiches in the field. 
The susceptibility of some licensed faba bean cultivars to the three pathogens involved in this study suggest that root diseases should be added to the list of other potentially destructive diseases of faba bean in Manitoba (Bernier, 1975). 
2. Host Range and Pathogenic Variability of Aphanomyces euteiches Isolates From Faba Bean

\begin{abstract}
The host range of Aphanomyces euteiches Drechs. isolated from naturally infected seedlings of faba bean (Vicia faba L.) at the University of Manitoba was investigated. Only leguminous species became infected in the field and the greenhouse. Twelve species were infected, of which the following do not appear to have been previously reported as hosts of A. euteiches: Lathyrus ochroleucus Hook., L. Sativus L., Lens culinaris Medic., Vicia calcarata Desf., $\underline{V}$. cracca L., $\underline{V}$. disperma $D C ., \underline{V}$. narbonensis $L$. and $\underline{V}$. tetrasperma (L.) Schreber.

The faba bean isolate AEl differed in pathogenicity from a Wisconsin pea isolate P14, which was avirulent on faba bean, whereas AEl was virulent on both. Three pathotypes were identified among the Manitoba isolates of $\mathrm{A}$. euteiches. Pathotypes AE1, AE2 and AE3 were pathogenic to peas; pathotypes $A E 1$ and $A E 3$ were distinguished on a pea cultivar to which $\mathrm{AE} 1$ was not aggressive and $\mathrm{AE} 3$ was avirulent on faba bean and lentil.

Inoculum concentration, age of seedlings at time of inoculation and temperature influenced disease development. Tolerance of the cultivars Ackerperle (faba bean) and Trapper (field pea) was overcome at $30^{\circ} \mathrm{C}$ (air temperature).
\end{abstract}




\section{INTRODUCTION}

A severe seedling blight and root rot had been observed in faba bean experimental field plots at the University of Manitoba ( $U$ of $M$ ) since 1978. Infected seedlings were stunted and had extensive black discoloration of the root system and epicotyls. Under high moisture conditions, the disease incidence and severity were high and entire plots of faba bean were affected. Fusarium spp. and Rhizoctonia solani Kuehn were isolated in 1979, but typical symptoms could not be reproduced in faba bean seedlings inoculated with recovered isolates of the two fungi.

In 1980 , the etiology of seedling blight was investigated more thoroughly. Aphanomyces euteiches Drechs. was isolated from fieldinfected seedlings, along with the two previous fungi and shown to be the main agent of the disease at the $U$ of $M$ Campus farm (Thesis Section I). Early surveys in Manitoba indicated that root rot was associated with Sclerotinia sclerotiorum (Lib.) de Bary, Fusarium spp. and $\underline{\text { R. }}$ solani

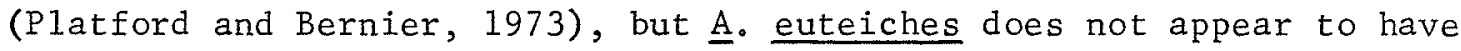
been associated with root rot of faba beans in the field. In the USA, A. euteiches and Aphanomyces cochlioides Drechs. still cause serious diseases of peas and sugar beets, respectively, and an extensive review on these pathogens has been published (Papavizas and Ayers, 1974). In addition to peas, $\underline{A}$. euteiches has been reported to infect several leguminous species (Linford, 1927; Sherwood and Hagedorn, 1962), as we11 as nonleguminous species (Car1son, 1965). Pathogenic variability has been 
found in $\underline{A}$. euteiches and races identified (Beute and Lockwood, 1967; Carley, 1969; Sundheim, 1972).

This study was initiated to provide further information on the host range of the faba $b$ " $n$ isolate recovered in Manitoba and to compare it to a Wisconsin pea isolate for pathogenicity. Pathogenic variability among Manitoba isolates of $\underline{A}$. euteiches and some factors affecting disease development in the greenhouse were also evaluated. 


\section{MATERIALS AND METHODS}

Roots and epicotyls from plants infected in the field and in the greenhouse were processed as described previously (Thesis Section I) and planted on $2 \%$ water agar (WA) for fungal isolation.

Inoculum was prepared and 7-day-old seedlings inoculated as previously described (Thesis Section I). Greenhouse experiments were carried out under continuous 1 ight at a temperature of $20-24^{\circ} \mathrm{C}$. When controlled environment rooms were used, the photoperiod was adjusted to $18 / 6$ hours and the temperature at $25 / 20^{\circ} \mathrm{C}$ (day/night).

\section{Host Range and Pathogenic Variability}

Twenty-nine plant species, including 11 species previously reported to be hosts of $\underline{A}$. euteiches (Papavizas and Ayers, 1974) were evaluated in the greenhouse using mycelial and zoospore. inoculum of the Aphanomyces isolate AEl from faba bean as well as by planting in naturally infested field soil. Some plant species were also evaluated in a field at the $U$ of $M$, previously found to be naturally infested with the pathogen (Thesis Section I) and hereafter referred to as the disease nursery.

Tests to differentiate between isolates recovered at the $U$ of $M$ and to compare the faba bean isolate $A E 1$ to the Wisconsin pea isolate P14 (supplied by Dr. Pfender, Wisconsin, USA) were carried out in controlled environment rooms. The test cultivars were grown in a pasteurized soil:sand:peat $\operatorname{mix}(1: 1: 1 ; \mathrm{v} / \mathrm{v} / \mathrm{v})$ in plastic flats. The flats contained one row (10-12 seedlings) of each cultivar. Ten m1 of a $10^{5}$ zoospores/ml suspension were poured per row, next to the stem of 
7-day-old seedlings. All isolates tested originated from hyphal tips. Single zoospore cultures from each isolate were also tested.

\section{Factors Affecting Disease Development}

To assess the relationship between seedling age and susceptibility of faba bean, the cultivars Ackerperle and PI 222128 were planted at weekly intervals for 3 consecutive weeks and then inoculated with mycelium of $\underline{\text { A. }}$ euteiches.

The effect of inoculum concentration on disease development was evaluated by inoculating plants of the susceptible cultivar PI 222128 with $0,10^{3}, 10^{4}, 2 \times 10^{4}, 4 \times 10^{4}$ and $10^{5}$ zoospores/plant (zsp/plant) poured in $2 \mathrm{ml}$ aliquots next to the stem of each seedling.

Four constant air temperature regimes, ranging from 10 to $30^{\circ} \mathrm{C}$, were also tested for their effect on disease development. Soil temperature was usually 2 to $4^{\circ} \mathrm{C}$ lower than air temperature at 25 and $30^{\circ} \mathrm{C}$.

Isolation and Distribution of $\underline{A}$. euteiches

The isolation of $\underline{A}$. euteiches from field infected plants was found to be difficult because of fungal and bacterial contaminations. The use of newly infected seedlings appeared to improve the frequency of isolation of Aphanomyces (Thesis Section I), therefore a test was conducted to determine the optimal time after planting for isolation of the fungus. The cultivars Ackerperle, Diana and PI 222128 were planted in five $3 \mathrm{~m}$-rows in a naturally infested field. Plants of the cultivars were uprooted when they were 11-, 23-, 40- and 49-day-old and used for fungal isolation.

To detect the presence of $\underline{A}$. euteiches in experimental fields at 
the Campus farm ( $U$ of $M$ ), soil was sampled and tested according to the method of Sherwood and Hagedorn (1958) as described in Appendix 5.

Disease rating. Plants were scored for disease on a scale ranging from 0-4 adapted from Smith and Walker's (1941) and previously described (Thesis Section I) where $0=$ healthy white roots, 1 = cortical black discoloration of tap root, 2 = black discoloraticn of the tap and lateral roots and epicotyl, but no decay, 3 = black areas soft, epicotyls water soaked and $4=$ tissues disintegrated. Dead plants were rated 4. A disease severity index (DSI) was computed as follows (Sherwood and Hagedorn, 1958):

$$
\operatorname{DSI}(\%)=\left(\sum_{i=0}^{4} n i \times i / \sum_{i=0}^{4} n i\right) \times 25
$$

where $X_{i}=$ class value $(0,1,2,3,4)$ and $n i=$ number of plants in class Xi. 
RESULTS

\section{Host Range}

Field and greenhouse studies on the host specificity of the $\underline{A}$. euteiches isolate AE1 are summarized in Table 1. Amongst the leguminous species tested, alfalfa (Medicago sativa L。), chickpea (Cicer arietinum L.), soybean (Glycine max L.) were immune; Vicia americana Muh1. and $\underline{V}$. lutea $L$. showed a brown discoloration, without decay, at the site where mycelial inoculum was applied but were not affected when inoculated with zoospores or planted in naturally infested soil. Snap beans (Phaseolus vulgaris L.) were mildly infected when inoculated with mycelium, but not by the other methods. $\underline{\text {. cracca }}$ L. and Lathyrus ochroleucus Hook. were moderately susceptible; the fungus grew 2-3 down the roots but did not infect the stem. The other leguminous species were susceptible to very susceptible(large portions of the roots and part of the stems discolored, stunting and death). Among the susceptible species, Lathyrus ochroleucus, I. sativum L。, lentils (Lens culinaris Medic.), $\underline{V}$. calcarata Desf., $\underline{V}$. cracca $L_{0}, \underline{V} \cdot \underline{\text { disperma }}$ DC。, $\underline{V}_{0}$ narbonensis L. and V. tetrasperma (L.) Schreber do not appear to have been previously reported as hosts of A. euteiches. None of the nonleguminous species tested became infected with any inoculation method (Table 1). A. euteiches was isolated from plants of all species infected in naturally infested soil and re-isolated from plants infected in the greenhouse. 
TABLE 1. Response of leguminous and non-leguminous species to infection by Aphanomyces euteiches from vicia faba.

\begin{tabular}{|c|c|c|c|c|}
\hline & Mycelium* & Zoospores ${ }^{*}$ & $\begin{array}{l}\text { Field soil } \\
\text { in greenhouse }\end{array}$ & Field $d^{* *}$ \\
\hline \multicolumn{5}{|l|}{ Leguminosae } \\
\hline Cicer arietinum $\mathrm{L}$. & - & - & - & - \\
\hline Lathyrus sativus $\mathrm{L}$. & + & + & + & $\mathrm{nt}$ \\
\hline L. ochroleucus Hook. & + & + & + & nt \\
\hline Lathyrus sp. & + & + & + & + \\
\hline Lens culinaris Medic. & + & + & + & + \\
\hline Medicago sativa L. & - & - & - & - \\
\hline Phaseolus aureus L. & - & - & nt & - \\
\hline Phaseolus vulgaris I. & $+/-$ & - & - & - \\
\hline Pisum sativum I. & + & + & + & + \\
\hline Pisum sativum arvense $\mathrm{L}$. & + & + & + & + \\
\hline Vicia americana Muh1. & - & - & - & $n t$ \\
\hline$\underline{v}$ angustifolia Reich. & + & + & + & nt \\
\hline Vicia calcarata Desf. & + & + & $n t$ & nt \\
\hline$\underline{V}$ cracca $\mathrm{L}$. & + & + & $\mathrm{nt}$ & $\mathrm{nt}$ \\
\hline$\underline{\mathrm{v}}$. disperma $\mathrm{DC}$. & + & + & + & nt \\
\hline V. faba $L$. & + & + & + & + \\
\hline v. $\underline{\text { lutea }} \mathrm{L}$. & - & - & - & nt \\
\hline v. monantha Retz. & + & + & + & $n t$ \\
\hline$\underline{\mathrm{V}}$. narbonensis $\mathrm{L}$. & + & + & + & nt \\
\hline$\underline{v}$. tetrasperma (L.) Schreber & + & + & + & $\mathrm{nt}$ \\
\hline Glycine max $\mathrm{L}$. & - & - & - & - \\
\hline \multicolumn{5}{|l|}{ Chenopodiaceae } \\
\hline Beta vulgaris $\mathrm{L}$. & - & - & - & - \\
\hline \multicolumn{5}{|l|}{ Liniaceae } \\
\hline$\underline{\text { Linum usitatissimun }} \mathrm{L}$. & nt & - & - & - \\
\hline \multicolumn{5}{|l|}{ Cruciferae } \\
\hline Brassica campestris $L$. & - & - & - & - \\
\hline B. napus $L$. & - & - & - & - \\
\hline Raphanus sativus $\mathrm{L}$. & - & - & - & nt \\
\hline \multicolumn{5}{|l|}{ Solanaceae } \\
\hline Lycopersicum esculentum L. & - & - & - & \\
\hline Solanum triberosum $\mathrm{L}$. & nt & nt & nt & - \\
\hline
\end{tabular}

$-=$ no infection; $+=$ infected; $+/-=$ infection restricted to infection site (decay) in inoculations with mycelium; nt = not tested.

* Observations based on at least 15 plants. All inoculation experiments were repeated at least twice.

** Cultivars planted in a naturally infested soil. Three 3 -m-rows were planted for each cultivar tested in the field. 
Comparative Virulence of a Faba Bean Isolate and a Wisconsin Pea Isolate

The virulence patterns of the two isolates differed greatly when three pea and two faba bean cultivars were inoculated with a $2 \times 10^{5}$ $\mathrm{zsp} / \mathrm{ml}$ suspension (Fig. 1). The Wisconsin pea isolate (P14) killed plants of the pea cultivars faster than the faba bean isolate, but was not pathogenic to faba bean. Only a few oospores were formed by P14 in the root cortex of plants of the faba bean cultivar PI 222128, but were not found in plants of Ackerperle. The faba bean isolate AEl heavily infected plants of the Little Marvel pea and PI 222128 (Fig. 1).

In a second test including additional cultivars and a lower inoculum concentration $\left(10^{5} \mathrm{zsp} / \mathrm{ml}\right)$, peas were killed faster by isolate P14, whereas Lathyrus sp. and lentils were more susceptible to the faba bean isolate (Table 2). Plants of Ackerperle and PI 222128 were only infected by the faba bean isolate. Neither isolate infected snap beans.

Pathogenic Variability Among Manitoba Isolates of A. euteiches

Preliminary tests with seven isolates recovered from different experimental fields at the $U$ of $M$ Campus farm resulted in the identification of three pathotypes based on the virulence patterns produced by inoculating faba bean, pea and lentil cultivars. Five isolates were similar to the type isolate ( $A E 1)$, whereas each of the two other isolates had a particular virulence pattern and were, therefore designated $\mathrm{AE} 2$ and $\mathrm{AE} 3$. Further testing of $\mathrm{AE} 1, \mathrm{AE} 2$ and $\mathrm{AE} 3$ resulted in the same virulence patterns observed in the previous test (Fig. 2). All three pathotypes were virulent on peas; pathotypes AE1 and AE2 were differentiated by the pea cultivar Homesteader to which AEl was not aggressive, whereas $\mathrm{AE} 3$ was avirulent on the faba bean and lentil cultivars. Pathotypes AEI and AE3 were isolated from plants of faba bean (PI.222128) 


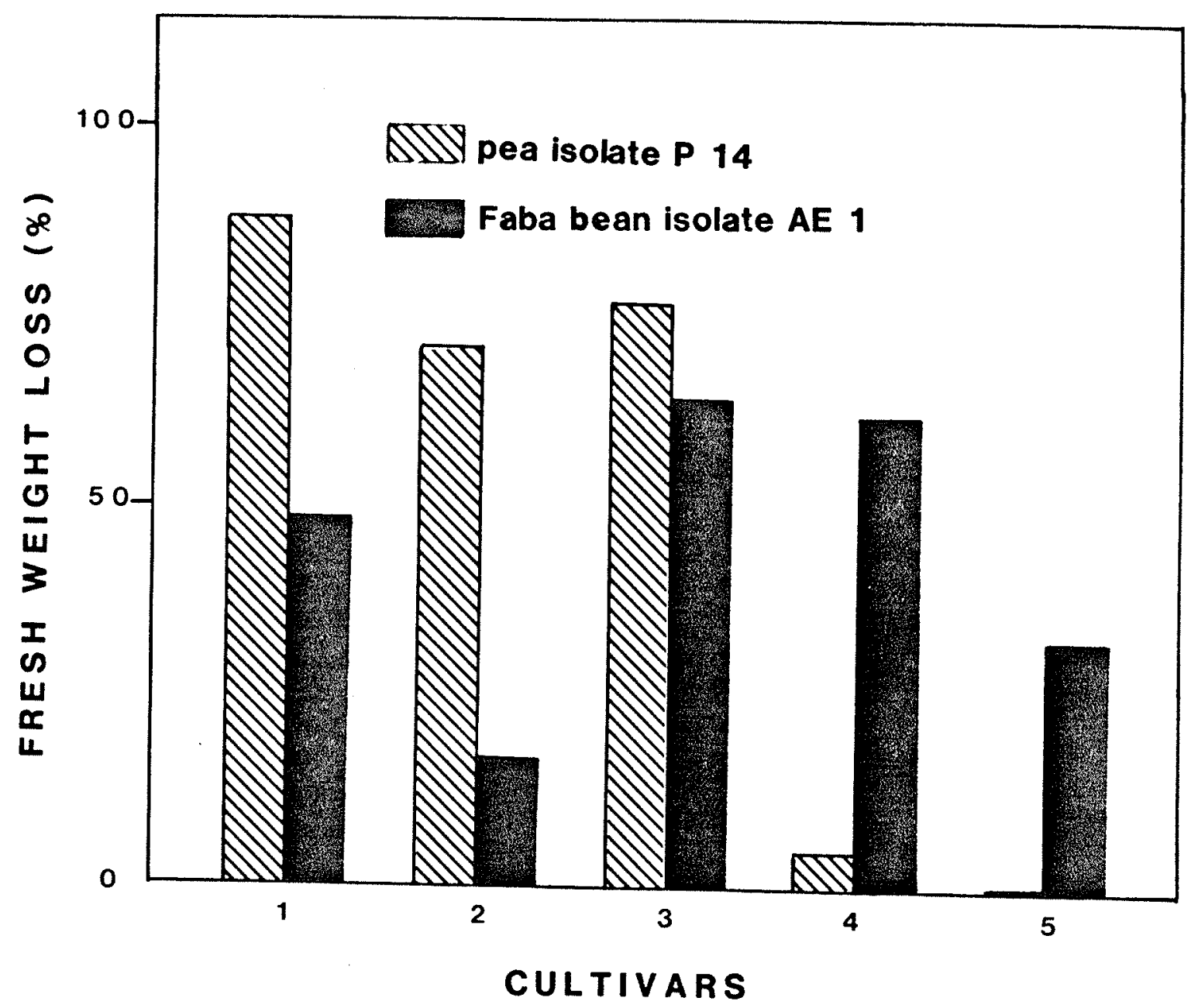

Figure 1. Virulence patterns of a faba bean isolate (AE 1) and a Wisconsin pea isolate ( $P$ 14) of Aphanomyces euteiches on five legume cultivars. The test cultivars were inoculated with $10 \mathrm{ml}$ of a $2 \times 10^{5}$ zoospores $/ \mathrm{ml}$ suspension per row (10-12 seedlings). 1- Miragreen, 2- Homesteader, 3- Little Marve1, 4Ackerperle, 5- PI 222128. Cultivars \#\# 1, 2, and 3 are peas and cultivars \# 4,5 are faba beans. 
TABLE 2. Response of 12 legume cultivars to inoculation with a faba bean isolate ( $\mathrm{AE} 1$ ) and a Wisconsin pea isolate (P14) of A. euteiches.

\begin{tabular}{|c|c|c|c|}
\hline Host & Cultivar & $\mathrm{P} 14^{*}$ & $\mathrm{AE} 1 *$ \\
\hline \multirow[t]{2}{*}{ Faba bean } & PI 222128 & - & $H$ \\
\hline & Ackerperle & - & + \\
\hline \multirow[t]{2}{*}{ Snap bean } & Kentucky Wonder & - & - \\
\hline & Bountiful1 & - & - \\
\hline \multirow[t]{2}{*}{ Lentil } & Brown lentil & + & $H$ \\
\hline & White lentil & ++ & $H$ \\
\hline \multirow[t]{5}{*}{ Pea } & Century & $+1+$ & $H$ \\
\hline & Tara & $H$ & + \\
\hline & Trapper & $+H$ & $H$ \\
\hline & Triumph & + & + \\
\hline & Little Marvel & $H$ & $H$ \\
\hline Lathyrus sp. & & $H$ & +1 \\
\hline
\end{tabular}

,,$++ H+$, respectively $=$ slight, moderate and severe infection. - = no infection.

Observations made on 50-60 plants/cultivar.

* Observations made on 15-20 plants/cultivar. 

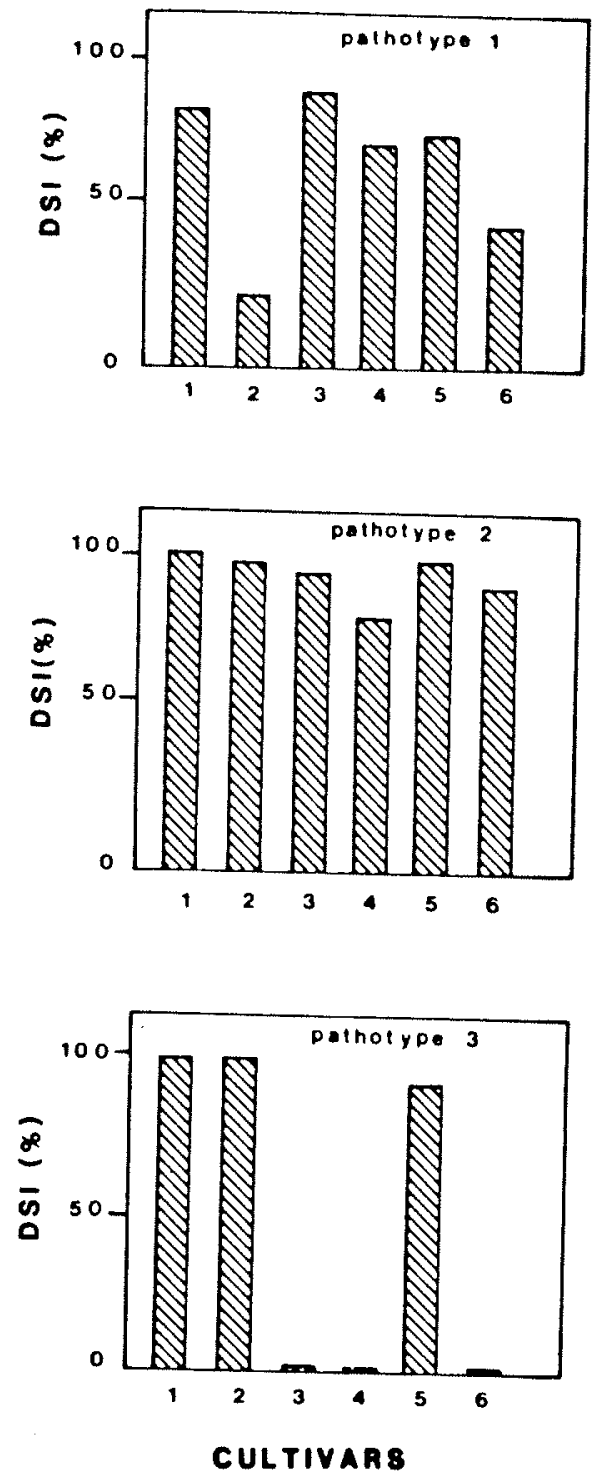

Figure 2. Virulence patterns of isolates of Aphanomyres euteiches from the University of Manitoba in six legume cultivars. The test cultivars were inoculated with $10 \mathrm{ml}$ of a $10^{5}$ zoospores/ml suspension per row (lo12 seedlings). 1 - Little Marvel (pea), 2- Homesteader (pea), 3- PI 222128 (faba bean), 4-Ackerperle (faba bean), 5-Trapper (field pea), 6- Tekoa (lentil). 
and field pea (Tara), respectively, infected in the disease nursery. Pathotype AE2 was isolated from plants of PI 222128 infected in a different field than the two previous pathotypes. Differences in virulence patterns were not observed between cultures started from hyphal tips or single zoospores.

Factors Affecting Disease Development

Results of studies to determine the influence of seedling age at the time of inoculation on disease development are shown by Figure $3 a$ and $b$. Inoculation of 7-day-old seedlings with mycelium resulted in a high percentage of plants killed and fresh shoot weight loss for both PI 222128 and Ackerperle. On the other hand, inoculation of 3week-old seedlings did not cause significant losses in either cultivar. Significant differences between Ackerperle and PI 222128, both in terms of the percentage of plants killed and fresh weight loss, were observed when 2-week-old seedlings were inoculated.

Increasing inoculum concentrations had a significant effect on the DSI, percentage of plants killed and fresh shoot weight loss in plants of the cultivar PI 222128 (Fig. 4). Significant differences with respect to the non-inoculated control were not observed below $10^{4} \mathrm{zsp} / \mathrm{plant}$

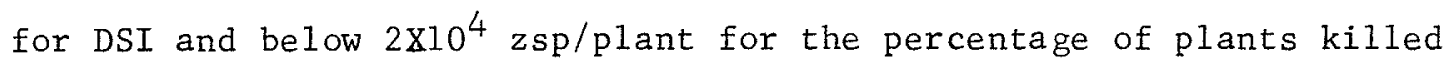
and fresh weight loss. Maximum DSI was observed with $2 \times 10^{4} \mathrm{zsp} / \mathrm{plant}$ and $60 \%$ of the seed 1 ings were killed and fresh weight was reduced by $70 \%$ at $10^{5} \mathrm{zsp} / \mathrm{plant}$.

Increasing temperatures (from 10 to $30^{\circ} \mathrm{C}$ ) resulted in increased disease development as measured by the reduction in fresh shoot weights (Fig. 5). Plants of PI 222128 were significantly more affected than plants of Ackerperle and Trapper at 15 and $25^{\circ} \mathrm{C}$ (air temperature). 


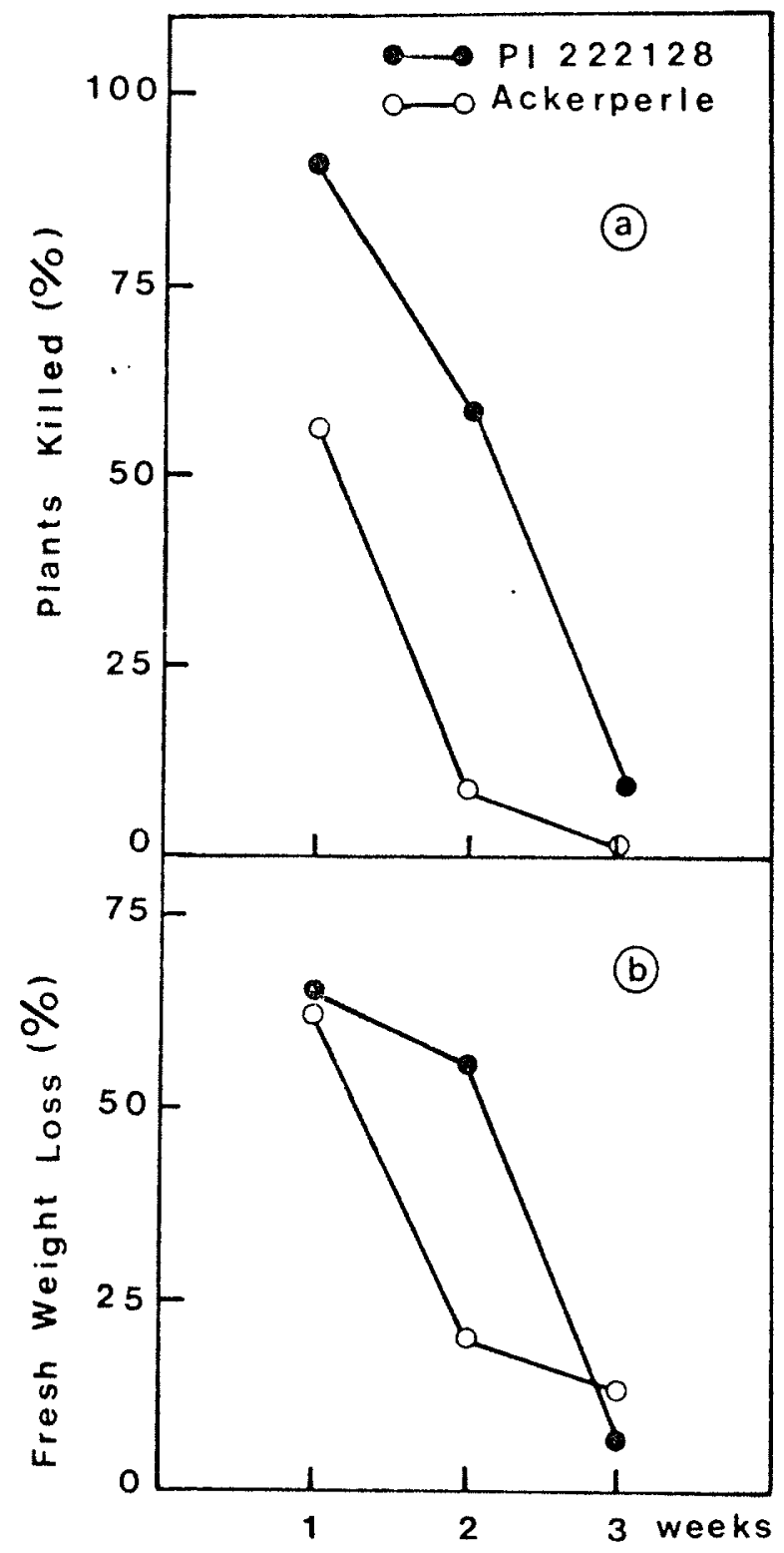

Age of Seedlings at Inoculation

Figure 3. Effect of seedling age at time of inoculation on disease development. Disease expressed as a) $\%$ plants killed, and b) fresh weight loss/plant $(\%)$. 


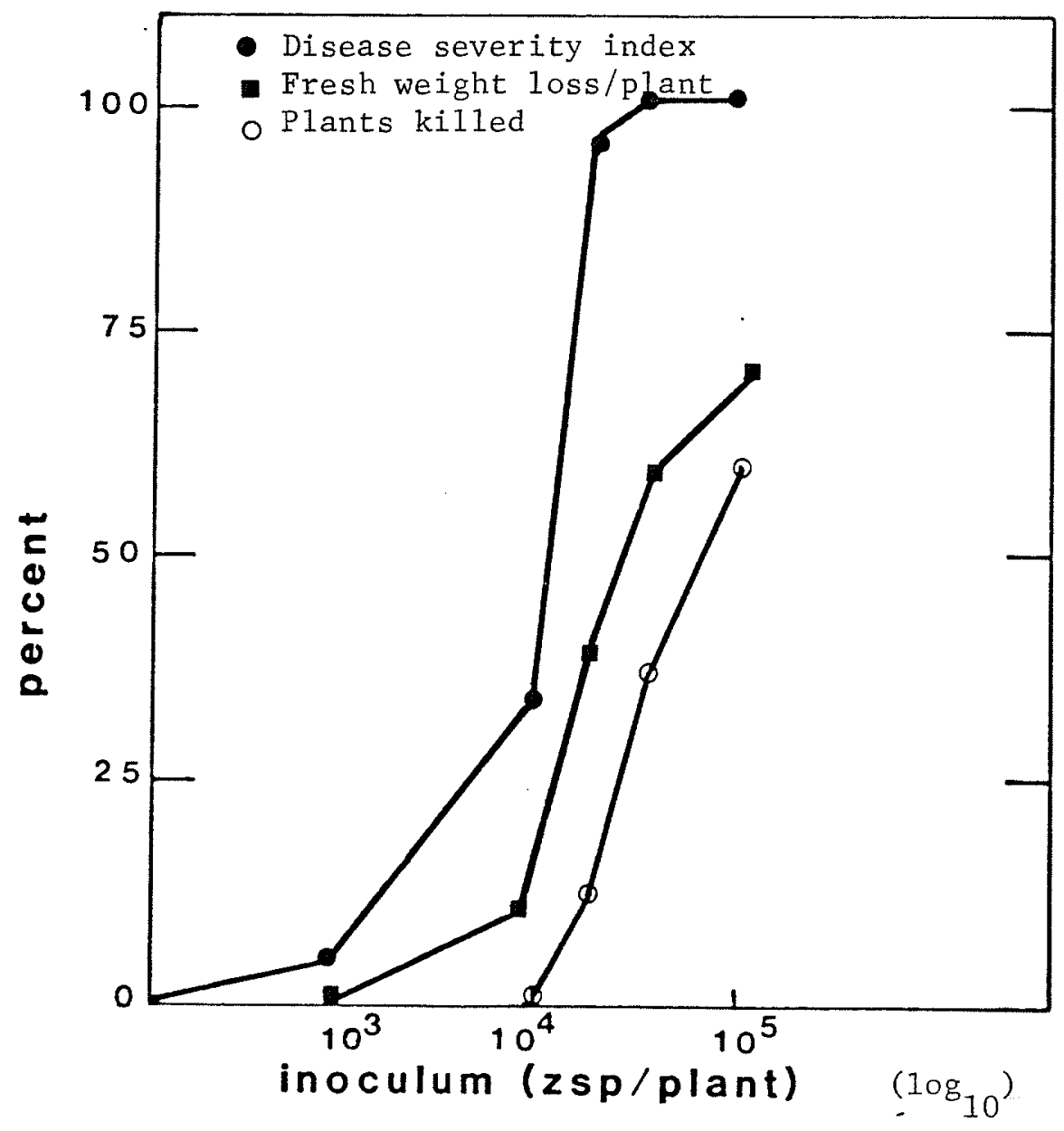

Figure 4. Effect of inoculum concentration on disease development. Treatments were replicated 5 times (12-16 plants/replication). 


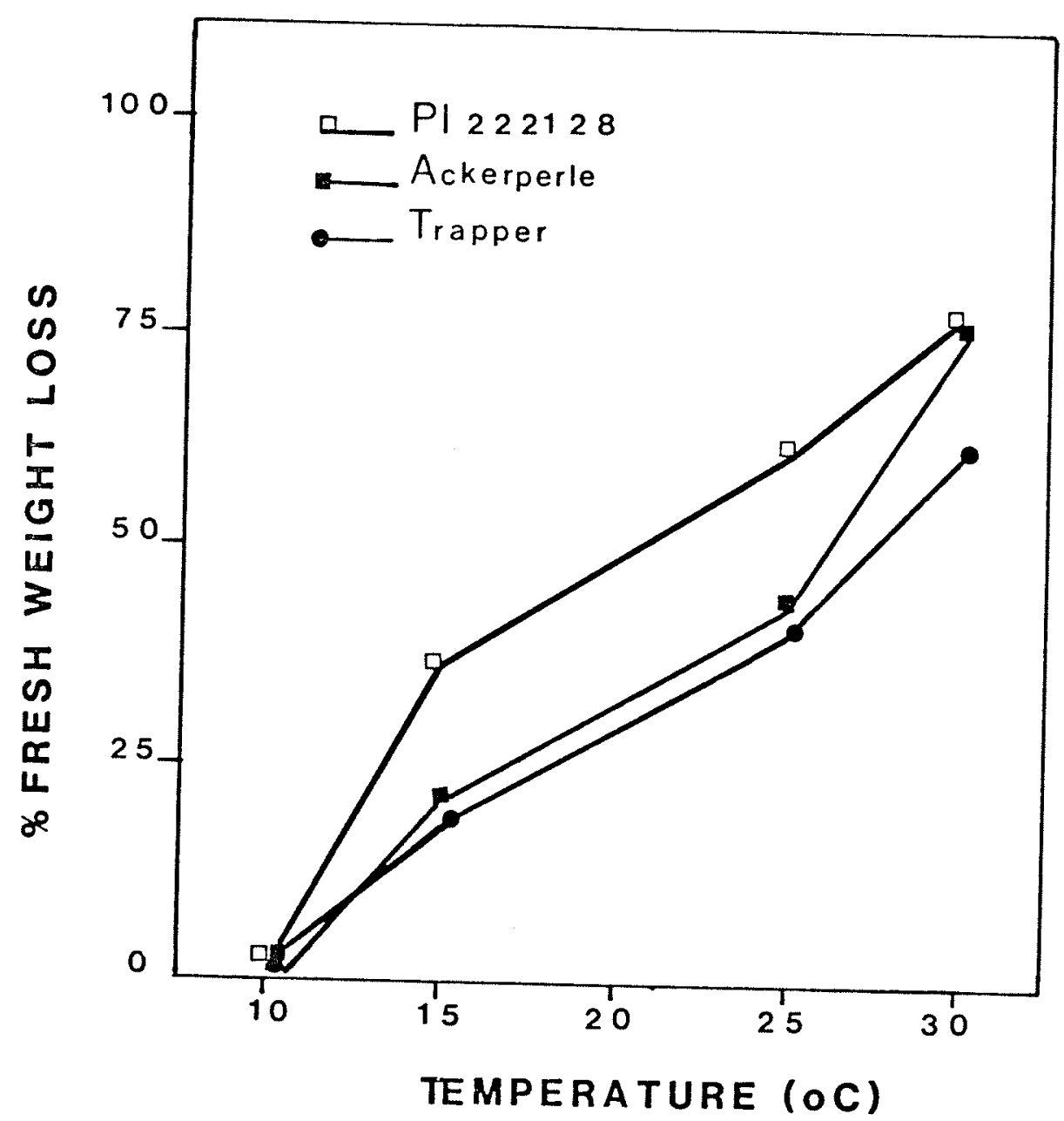

Figure 5. Effect of temperature on disease development. Soil temperatures were $2-4^{\circ} \mathrm{C}$ lower than air temperatures. Treatments were replicated 3 times (20-24 plants/replication). 
At $30^{\circ} \mathrm{C}$, fresh shoot weight losses ranged from $60-75 \%$ and plants of al1 cultivars were dead 10 days after inoculation. Disease symptoms were not observed at $10^{\circ} \mathrm{C}$ with any of the cultivars tested.

Recovery of A. euteiches from Field-Infected Seedlings of Faba Beans Recovery of $\underline{A}$. euteiches on $2 \%$ WA from field-infected faba bean plants was highest 11 days after planting (92\%) and lowest (2.3\%) after 49 days (Fig。6). Fusarium spp. and other fungi were recovered more frequently from dead roots and epicotyls at the end of the test period. The best sampling time for isolation of $\underline{A}$. euteiches from faba bean plants appears to be between 1 and 3 weeks after germination in naturally infested fields.

Distribution of A. euteiches at the U of M Experimental Fields

A. euteiches was detected in five of eight fields assayed (Table 3). The infested soil samples contained enough propagules of the pathogen to induce root and epicotyl discoloration in plants of PI 222128. Even though a limited number of fields were sampled, the results suggest a positive relationship between the number of previous pea and/or faba crops and the infestation with $\underline{A}$. euteiches. The assay used in this study did not detect the fungus in fields 非 7 and 11, where peas and faba beans had not been cropped for 3 and 6 years, respectively. 


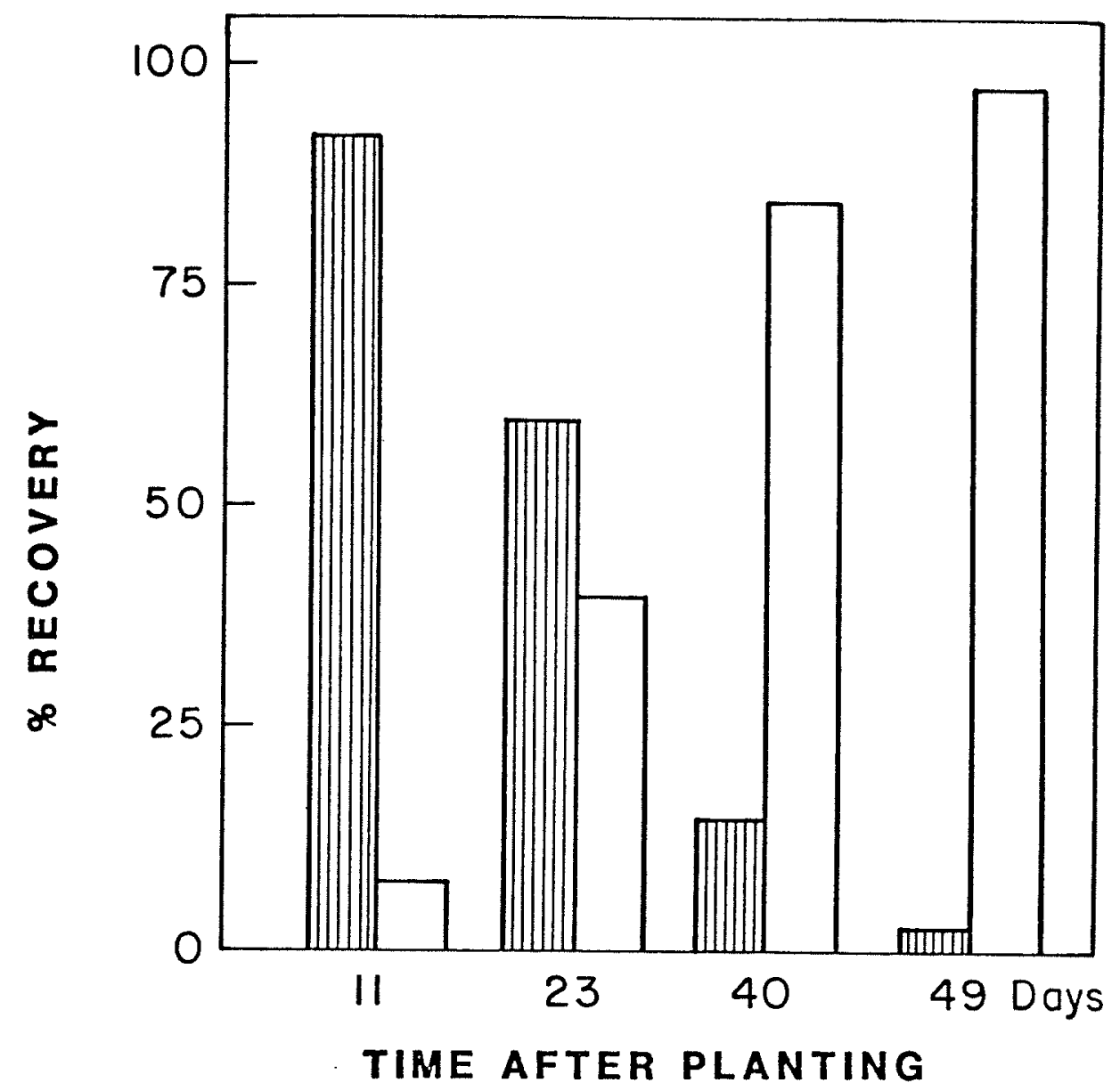

Figure 6. Effect of the growth stage of naturally infected faba bean plants on the frequency of isolation of Aphanomyces euteiches. Fungal isolations were made on $2 \%$ water agar from at least 30 plants of the cultivars Ackerperle, Diana and PI 222128. Values represent means of recovery from the three cultivars. $\mathbf{H m}$ A. euteiches, $\square$ Fusarium sp. and other fungi. 
TABLE 3. Isolation of Aphanomyces euteiches from infested soil samplea at the University of Manitoba and assayed in the greenhouse.

\begin{tabular}{|c|c|c|c|c|c|}
\hline \multirow[b]{2}{*}{ Field No } & \multicolumn{2}{|c|}{ Crops in Past 12 Years } & \multirow{2}{*}{$\begin{array}{l}\text { Years without } \\
\text { pea \& faba bean }\end{array}$} & \multirow{2}{*}{$\begin{array}{c}\text { Isolation* } \\
\text { of } \underline{A} \text {. euteiches }\end{array}$} & \multirow[b]{2}{*}{ DSI $(\%$} \\
\hline & Pea & Faba bean & & & \\
\hline 1 & 4 & 1 & 1 & + & 45.8 \\
\hline 2 & 4 & 1 & 1 & + & 85.4 \\
\hline 5 & 5 & 2 & 1 & $+* *$ & na \\
\hline 6 & 3 & 1 & 1 & + & 87.5 \\
\hline 7 & 2 & 1 & 3 & - & 0.0 \\
\hline 8 & 2 & 2 & 2 & + & 65.6 \\
\hline 11 & 4 & 0 & 6 & - & 0.0 \\
\hline 18 & 3 & 3 & 1 & + & 87.5 \\
\hline
\end{tabular}

*A. euteiches was isolated on $2 \%$ water agar from 2 -week-old seedlings.

** A. euteiches isolated from field-infected seedlings.

DSI represents average of 4 pots, each planted with 4 seeds of the faba bean cultivar PI 222128.

na $=$ not available. 
of tolerant plants (rating 1-2). Plants of the tolerant accessions also had many new white lateral roots.

Seedling blight and root rot were generally more severe in 1981 because of a relatively wet period early in the season and more accessions were blighted than in 1980 . Only $17 \%$ of the accessions were rated 1 (no apparent symptoms) as shown in Figure $1 \mathrm{~b}$. $\underline{A}$. euteiches was isolated from the plants uprooted to observe root systems. As in 1980, immunity was not observed. The following accessions were identified as tolerant: 2N22, 2N26, 2N32, 2N37, 2N54, 2N58, 2N62, $2 \mathrm{~N} 71,2 \mathrm{~N} 74,2 \mathrm{~N} 83,2 \mathrm{~N} 97,2 \mathrm{~N} 106,2 \mathrm{~N} 196,2 \mathrm{~N} 217,2 \mathrm{~N} 229,2 \mathrm{~N} 355,2 \mathrm{~N} 371$, $2 \mathrm{~N} 475,2 \mathrm{~N} 478,2 \mathrm{~N} 480,2 \mathrm{~N} 486,2 \mathrm{~N} 487,2 \mathrm{~N} 509,2 \mathrm{~N} 511,2 \mathrm{~N} 517,2 \mathrm{~N} 518,2 \mathrm{~N} 519$, $2 \mathrm{~N} 520,2 \mathrm{~N} 522,2 \mathrm{~N} 523$ and $2 \mathrm{~N} 534$.

The accessions selected during the 1980 season for tolerance to root rot again expressed tolerance in 1981 (Fig。1C), with the exception of nine accessions. The reactions of the selections in the three replications were not always consistent due to a non-uniform distribution of the pathogen in the field. The use of PI 222128 as a susceptible control allowed the detection of non-infested areas in the field and thus reduced the possibility of selecting material that had escaped infection (Appendix 3).

The following selections exhibited tolerance in each of the three replications and were reselected: $2 \mathrm{~N} 19,2 \mathrm{~N} 21,2 \mathrm{~N} 37,2 \mathrm{~N} 66,2 \mathrm{~N} 68,2 \mathrm{~N} 94$, $2 \mathrm{~N} 104,2 \mathrm{~N} 112,2 \mathrm{~N} 114,2 \mathrm{~N} 116,2 \mathrm{~N} 134,2 \mathrm{~N} 140,2 \mathrm{~N} 218,2 \mathrm{~N} 236,2 \mathrm{~N} 296, \mathrm{DN} 75-38$ (ERF) and DN76-8. Two to three bagged single plants from each selection were harvested separately.

In addition to their tolerance to root rot in the field, the selections 2 N19, 2N94, 2N112 and 2N134 appeared to outyield all the 
DISCUSSION

The pathotypes of $\underline{A}$. euteiches recovered at the University of Manitoba appear to be restricted to leguminous species, since nonleguminous species were not infected by this fungus under greenhouse and field conditions. Lathyrus ochroleucus, L. sativus, Lens culinaris, $\underline{V} \cdot \underline{\text { calcarata, }} \underline{\mathrm{V}} \cdot \underline{\text { cracca }}, \underline{\mathrm{V}}$. disperma,$\underline{\mathrm{V}}$. narbonensis and $\underline{\mathrm{V}}$. tetrasperma were infected by the fungus in this study and do not appear to have been previously reported as hosts of $\underline{A}$. euteiches. The results of the host range study generally agree with previous findings that several legumes may serve as alternative hosts for $\underline{A}$. euteiches in the absence of peas, whereas non-leguminous species are not suitable hosts (Sherwood and Hagedorn, 1962).

The faba bean isolate AEl and the Wisconsin pea isolate P14, although morphologically similar, had different virulence patterns when compared on five legume cultivars (Fig. 1). Thus, they represent distinct pathotypes of A. euteiches, isolate P14 lacking the ability to çause disease on faba bean.

Three pathotypes were identified among the Manitoba isolates of A. euteiches. The use of faba bean, pea and lentil cultivars as a differential series in this study revealed the existence of a pathotype avirulent to faba bean (AE3). This pathotype would not have been detected had the test been carried out with the same pea differentials used in race identification elsewhere (Beute and Lockwood, 1967). The results of this study confirm previous findings regarding the physio- 
logic specialization in A. euteiches (Beute and Lockwood, 1967;

Carley, 1970; Sundheim, 1972). The presence of different pathotypes such as $A E 1$ and $A E 3$ in the same field may give $\underline{A}$. euteiches the possibility to recombine and evolve new pathotypes.

The origin of the infestation in the experimental fields at the $U$ of $M$ with $\underline{A}$. euteiches is not known. However, it is possible that inoculum built up on field peas which were frequently grown as a green manure crop over the past 20 years. This is supported by the fact that the faba bean crop is of recent introduction and that the field pea cultivars were only found to be moderately susceptible to this pathogen in the field. Disease on field peas may have gone unnoticed because, as revealed in the present study, symptoms were not observed on aerial parts of field infected plants.

In addition to field 非 18 used as a source of naturally-produced inoculum throughout the present study, several other fields at the U of M Campus farm were found to be infested with $\underline{\text { A }}$ euteiches, when assayed for the presence of this pathogen. The root rot potential, as expressed by the DSI, appears to be positively related to the number of previous pea and/or faba crops. This generally agrees with the findings of Temp (1966) that the number of pea crops, prior to the assay, was the largest single factor affecting the root rot potential of Wisconsin pea fields.

The tolerance of the cultivars Trapper and Ackerperle was overcome at high air temperature $\left(30^{\circ} \mathrm{C}\right)$. Whether this effect was due to an increased activity of the fungus and/or temperature stress on the seedlings, cannot be inferred from this study. These findings are not in agreement with those of Lockwood (1960a) who found that soil temper- 
ature of $28^{\circ} \mathrm{C}$ did not alter pea tolerance to $\underline{A}$. euteiches.

Resistance of faba bean seedlings to $\underline{A}$. euteiches was found to increase with age but not to the same extent in all cultivars. Seedlings of PI 222128 appear to have a longer period of susceptibility than those of Ackerperle (Fig. 3a, b). Significant differences in both fresh shoot weight losses and percentage of plants killed between PI 222128 and Ackerperle were only observed on 2-week-old inoculated seedlings. Similar results were obtained by Schneider (1956) for the black root disease of sugar beets, induced by $\underline{A}$. cochlioides.

In this study, inoculum concentrations were found to influence disease development, as expressed by the DSI, percentage of plants killed or fresh shoot weight loss. Furthermore, typical symptoms were not induced on plants of the faba cultivar at inoculum levels of $2 \times 10^{4}$ $\mathrm{zsp} / \mathrm{plant}$ or lower, although root infection was observed to occur with inoculum as 1 ow as $10^{3} \mathrm{zsp} / \mathrm{plant}$. These results suggest that a threshold in inoculum concentration was required for induction of typical symptoms as previously reported for $\underline{A}$. cochlioides (MacWithey, 1965). However, studies by Carlson (1965) and Bhalla (1968) indicated that a threshold of inoculum concentration was not needed for infection of pea roots by zoospores of $\underline{A}$. euteiches.

The percentage recovery of $\underline{A}$. euteiches from field-infected faba bean seedlings appears to be strongly influenced by the age at which the seedlings are sampled for fungal isolation (Fig, 6), confirming previous observations (Thesis Section I).

The results of this study provide a better understanding on the seedling blight and root rot of faba bean in Manitoba and help in developing more effective control measures. 


\title{
3. Screening Faba Bean (Vicia faba) for Tolerance to Root Rot Caused by Aphanomyces euteiches
}

\begin{abstract}
Yield losses of five licensed faba bean (Vicia faba L.) cultivars were found to be very high when planted in a field naturally infested with Aphanomyces euteiches Drechs. The cultivars Ackerperle and Herz Freya expressed tolerance to root rot, whereas Erfordia and Diana suffered 64 and $72 \%$ yield losses, respectively. Variability in tolerance to Aphanomyces root rot was also found in 350 accessions tested in this study. Selection among and within the accessions resulted in the identification of tolerant accessions. The following faba bean accessions were considered tolerant after two seasons of testing: 2N19, $2 \mathrm{~N} 21,2 \mathrm{~N} 37,2 \mathrm{~N} 66,2 \mathrm{~N} 68,2 \mathrm{~N} 94,2 \mathrm{~N} 104,2 \mathrm{~N} 112,2 \mathrm{~N} 114,2 \mathrm{~N} 116,2 \mathrm{~N} 134,2 \mathrm{~N} 140$, 2N218, 2N236, 2N296, DN75-38 (ERF) and DN76-8.

Partial control of Aphanomyces root rot was achieved by seed treatment with Dowco 444 only and then for up to 5 weeks after planting. Seed rot and pre-emergence damping-off were not important during the two seasons of testing and the fungicides could not be evaluated for control of seed rot.
\end{abstract}




\section{INTRODUCTION}

Seedling blight and root rot of faba bean (Vicia faba L.) has been associated with Aphanomyces euteiches Drechs., Rhizoctonia solani Kuehn and Fusarium spp. in the experimental field plots at the University of Manitoba. Greenhouse tests showed that only $\underline{A}$. euteiches was able to reproduce the symptoms observed in the field (Thesis Section I).

Field infected plants were either killed in the seedling stage or severely stunted with premature yellowing of the foliage. Many cultivars of faba bean and other legumes were found to be very susceptible to A. euteiches in the field and greenhouse studies (Thesis Sections I and II)。

This long-lived soil-borne fungus is known for its pathogenicity to peas, in which it causes very heavy losses (Jones and Drechsler, 1925). Very few attempts have been made to control the common root rot of pea with fungicide seed treatments and effective control has not been achieved by this method (Papavizas and Ayers, 1974). However, soil treatments with Dexon at a rate of $30 \mathrm{lb}$ per acre effectively controlled the disease but the rate of application was not economically feasible (Mitchell and Hagedorn, 1971). The lack of success and the prohibitive cost of chemical control made the search for genetic resistance in peas an attractive alternative. Partial resistance has been reported by several workers (Johnson, 1953; King and Cho, 1962; Cho and King, 1963; Lockwood, 1960a, b; Shehata et al., 1976). However, immune or highly 
resistant pea cultivars have not been released from the screening or breeding programs.

In view of the potential economic importance of the disease, five licensed cultivars and some 350 faba bean accessions from different regions of the world were evaluated for their reaction to A. euteiches in the field. The effectiveness of selected fungicide seed treatments was also investigated. 
MATERIALS AND METHODS

An experimental field with a history of seedling blight and root rot of faba bean was used throughout this study and referred to as the disease nursery. The disease in the field was shown to be caused by a complex of root pathogens, including pathogenic $\underline{R}$. solani and $\underline{A}$. euteiches (Thesis Section I). The field had been cropped with faba bean since 1978. Fertilizer was not applied during this period but crop residues were plown under at the end of each season. Plots were sown with a mechanical seeder and the seed was inoculated with a commercial culture of Rhizobium leguminosarum (Frank) at the time of planting.

\section{Assessment of Yield Loss}

The Iicensed cultivars Ackerperle, Aladin, Diana, Erfordia and Herz Freya were planted in the Aphanomyces infested field and in a noninfested field at the University of Manitoba during the first week of May 1981. The plots consisted of four rows, 3-m-1ong and 30-cm apart and planted with 50 seeds per row. Nine replications of each cultivar were planted at each location in a randomized complete block design. Fresh shoot weights of plants from 2-m of a middle row of each plot were taken 3-months after planting. At this stage, the plants were still green but had formed pods. To estimate yield losses, two $2-m-$ rows were harvested at maturity, air dried for 3 weeks and threshed. Seed yield was recorded for each plot. 
Screening and Selection for Tolerance

In 1980, a total of 155 accessions (Appendix 6) and in 1981, 196 (Appendix 7) were planted in single 1 -m-row plots in an Aphanomyces infested field. Two months after planting, the accessions were rated for disease on a visual scale ranging from $1-4$, where $1=$ no apparent symptoms, 2 = normal growth but premature yellowing of the lower leaves, 3 = stunting and extensive yellowing of the foliage and $4=$ very pronounced stunting and most plants dead. The limited number of seeds planted did not allow uprooting of large numbers of plants for scoring root systems, particularly in the tolerant accessions which were to be saved for seed production. However, a few seedlings were uprooted to assess the presence of $\underline{A}$. euteiches. Most of the accessions were not uniform, possibly due to the partially-outcrossing nature of faba beans (Poulsen, 1975). Susceptible plants within a generally tolerant accession were discarded prior to harvest and only outstanding plants were harvested.

Thirty-eight selections (Appendix 3) from the 1980 accessions were tested in 1981. Each selection was sown in a 3-m-row (25 to 30 seeds) flanked on each side by one row of the susceptible PI 222128 to verify the presence of the pathogen and to detect potential disease escape. Three replications of each accession were planted in a randomized complete block design. Rating for disease was done as described for the accessions. Furthermore, plants from accessions without symptoms (i.e. class 1) located between severely infected plants of PI 222128 within each selection were enclosed with a nylon mesh bag to prevent cross pollination by bees. 
Seed Treatments with Fungicides

In 1980, seven fungicides were applied as a slurry to the seeds of the cultivar Ackerperle at the rates specified in Table 3 . The plots consisted of three rows, $3-\mathrm{m}-1$ long and $30 \mathrm{~cm}$ apart. Two sets of the same experiment were planted at 1-month intervals in the disease nursery and a third set near Beausejour in Eastern Manitoba on land where root rot had been reported in the crop the previous year (Thesis Section I).

In 1981, the fungicides were used to treat seeds of the cultivar Diana instead of Ackerperle, which was found to have some field tolerance to $\underline{A}$. euteiches. In the water-soaked treatments, the fungicides were added to a given amount of water and the seed soaked in the solution until all the liquid was absorbed. The seed was then dried and packaged. Acetone was used as a carrier in seed treatment with Terrazole. The fungicide was added to the acetone and the seeds soaked in the solution for 2 hours. The acetone was then allowed to evaporate in a fume hood. Plot sizes and design were similar to the 1980 experiment.

Plants from each plot were rated for disease and fresh shoot weights taken 5 and 8 weeks after planting. The disease was rated on a scale of 0-4 adapted from the scale described for pea by Smith and Walker (1941), where 0 = white healthy roots, 1 = cortical black discoloration on tap root, 2 = black discoloration on the tap and lateral roots and epicotyl, but no decay, 3 = black areas soft, epicotyls watersoaked and 4 = tissues disintegrated. A disease severity index (DSI) was computed according to the method of Sherwood and Hagedorn (1958): 


$$
\operatorname{DSI}(\%)=\left(\sum_{i=0}^{4} n i \mathrm{Xi} / \sum_{i=0}^{4} n i\right) \times 25
$$

where $\mathrm{Xi}=$ class value $(0,1,2,3,4)$ and $n i=$ number of plants in class Xi. 


\section{RESULTS}

Effect of Disease on Yield and Fresh Shoot Weights

Yields of the five cultivars were not significantly different in the non-infested field (Table 1). This was not the case, however, in the infested field where yields of Ackerperle, Herz Freya and Aladin were significantly superior to those of Erfordia and Diana. The percentage reduction in yield computed for each cultivar showed that Diana and Erfordia suffered significantly more losses than the three other cultivars. Fresh shoot weights, as well as the percentage reduction in fresh shoot weights, showed similar trends (Table 2).

\section{Evaluation of Faba Bean Accessions and Selections}

The season was particularly dry in 1980 and faba bean root rot was not severe on cultivars such as Ackerperle. However, $46 \%$ of the accessions were rated 3 and 4 (Fig. 1a) (i.e. extensive stunting, yellowing and death). Several accessions were entirely blighted during the first month after planting. The following accessions did not show yellowing nor stunting and were considered tolerant: 2N43, 2N296, $2 \mathrm{~N} 101,2 \mathrm{~N} 23,2 \mathrm{~N} 15,2 \mathrm{~N} 19,2 \mathrm{~N} 20,2 \mathrm{~N} 98,2 \mathrm{~N} 342,2 \mathrm{~N} 10,2 \mathrm{~N} 134,2 \mathrm{~N} 240,2 \mathrm{~N} 37$, $2 \mathrm{~N} 428,2 \mathrm{~N} 26,2 \mathrm{~N} 109,2 \mathrm{~N} 121,2 \mathrm{~N} 96,2 \mathrm{~N} 63,2 \mathrm{~N} 242,2 \mathrm{~N} 21,2 \mathrm{~N} 236,2 \mathrm{~N} 411,2 \mathrm{~N} 18$, $2 \mathrm{~N} 94,2 \mathrm{~N} 112,2 \mathrm{~N} 113,2 \mathrm{~N} 114,2 \mathrm{~N} 239,2 \mathrm{~N} 123,2 \mathrm{~N} 2,2 \mathrm{~N} 18$ and $2 \mathrm{~N} 11$.

Immunity to infection by $\underline{A}$. euteiches was not observed in plants of any of the accessions. Uprooted plants showed a black discoloration of the root system. The discoloration was extensive and deep in roots of susceptible accessions (categories 3 and 4) and superficial on roots 
TABLE 1. Effect of Aphanomyces root rot on the yield of five licensed faba bean cultivars.

\begin{tabular}{lccc}
\hline & $\begin{array}{c}\text { Non-infested } \\
\text { field } \\
(\mathrm{g})\end{array}$ & $\begin{array}{c}\text { Infested } \\
\text { field } \\
(\mathrm{g})\end{array}$ & \% Reduction ${ }^{+}$ \\
\hline Ackerperle & $406.1 \mathrm{a}$ & $218.3 \mathrm{a}^{*}$ & $46.2 \mathrm{a}^{*}$ \\
Herz Freya & $388.9 \mathrm{a}$ & $220.6 \mathrm{a}$ & $43.2 \mathrm{a}$ \\
Erfordia & $441.0 \mathrm{a}$ & $156.1 \mathrm{~b}$ & $64.6 \mathrm{~b}$ \\
Aladin & $455.2 \mathrm{a}$ & $212.0 \mathrm{a}$ & $53.2 \mathrm{a}$ \\
Diana & $389.0 \mathrm{a}$ & $107.7 \mathrm{c}$ & $72.3 \mathrm{~b}$ \\
LSD .01 & & 14.6 & 11.4 \\
\hline
\end{tabular}

Mean values of 8 replications for dry grain from two, 2-m-rows.

$+\%$ Reduction $=(1-$ infested/non-infested $) \times 100$.

*Treatments with same letter in the same column are not significantly different at $\mathrm{p}=.01$ (Duncan's Multiple Range Test). 
TABLE 2. Effect of Aphanomyces root rot on the fresh shoot weight of five licensed faba bean cultivars.

\begin{tabular}{lccc}
\hline & $\begin{array}{c}\text { Infested } \\
\text { field } \\
(\mathrm{g})\end{array}$ & $\begin{array}{c}\text { Non-infested } \\
\text { field } \\
(\mathrm{g})\end{array}$ & $\%$ Reduction \\
\hline Ackerperle & $1298.8 \mathrm{a}^{*}$ & $2201.3 \mathrm{ab}^{*}$ & $41.0 \mathrm{a}^{*}$ \\
Herz Freya & $1190.0 \mathrm{a}$ & $2058.6 \mathrm{bc}$ & $42.2 \mathrm{a}$ \\
Erfordia & $1193.6 \mathrm{a}$ & $2475.0 \mathrm{a}$ & $51.8 \mathrm{a}$ \\
Aladin & $1073.6 \mathrm{a}$ & $2350.0 \mathrm{ab}$ & $54.3 \mathrm{ab}$ \\
Diana & $717.5 \mathrm{~b}$ & $1816.3 \mathrm{c}$ & $60.5 \mathrm{~b}$ \\
LSD .01 & 323.6 & 323.6 & 14.6 \\
\hline
\end{tabular}

+ Fresh shoot weight of plants in $2 \mathrm{~m} \mathrm{row} / \mathrm{plot}$ data represent averages of 9 replications.

$+\%$ reduction in fresh shoot weight $=(1-$ infested $/$ non-infested) X 100 .

*Treatments with same letters, within the same column, are not significantly different at $p=.01$ (Duncan's Multiple Range Test). 


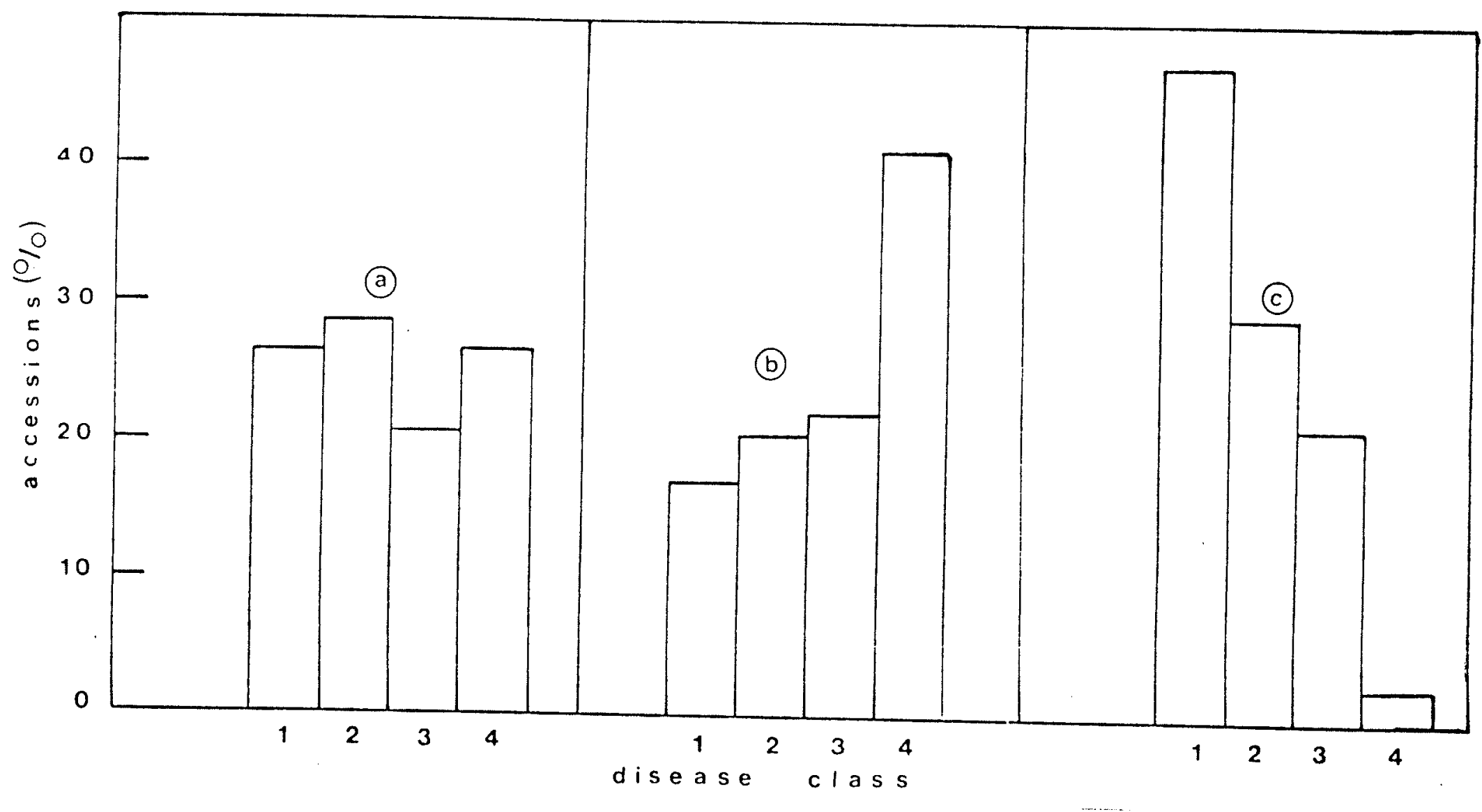

Figure 1. Frequency distribution of faba bean accessions in response to Aphanomyces root rot. a) 155 accessions tested in 1980 , b) 196 accessions tested in 1981 and c) 38 selections from the 1980 program re-tested in 1981 . Classes 1 and 2 represent tolerance and classes 3 and 4 represent susceptibility. 
licensed cultivars tested in 1981 in the same infested field (Table 3).

\section{Effect of Fungicide Seed Treatments on Disease Development}

Root rot was only moderately severe on the cultivar Ackerperle in the plots at the $U$ of $M$ in 1980 and that damage was not great was probably due to the fact that the cultivar Ackerperle had some tolerance to $\underline{A}$. euteiches under field conditions (Appendices 6 and 8 ; Tables 1 and 2). Significant differences in seedling emergence (stands) were not observed at the $U$ of $M$ for both dates of planting and also in the commercial field near Beausejour (Table 4).

In 1981, differences between stands were again not significant (Table 5). The experiment revealed that Ridomil had some phytotoxic effects when applied as a water soak treatment at the rate specified in Table 5. This property had not been observed in 1980 when the fungicide was applied as a slurry. Other treatments were not phytotoxic.

The differences between treatments both in terms of disease severity index (DSI) and fresh shoot weight/plant were significant at the first date of disease rating ( 5 weeks after planting) for both applications of Dowco 444 (Table 5). The fungicide was effective in restricting the disease, although the roots had the typical black discoloration caused by $\underline{A}$. euteiches as indicated by the isolation of the fungus from infected roots. The differences between the Dowco 444 treatments and the remaining treatments were significant for the DSI at the 5 and $1 \%$ levels, but not for the fresh shoot weight/plant (Table 5). At the flowering stage and later, the plants of all plots were stunted and had a premature yellow foliage. The plots were not harvested because seed set was very low or nil in all treatments including Dowco 444. 
TABLE 3. Comparative yield of four selections and five licensed faba bean cultivars in an Aphanomyces infested field.

\begin{tabular}{|c|c|c|c|}
\hline & \multicolumn{3}{|c|}{ Yield $(\mathrm{g})^{*}$} \\
\hline & \multicolumn{2}{|c|}{ Infested } & \multirow[t]{2}{*}{ Non-infested } \\
\hline & P1ot mean & Highest plot & \\
\hline \multicolumn{4}{|c|}{ Tolerant selections } \\
\hline $2 \mathrm{~N} 134$ & 327.4 & & \\
\hline $2 \mathrm{~N} 112$ & 317.4 & & \\
\hline $2 \mathrm{~N} 19$ & 293.8 & & \\
\hline $2 \mathrm{~N} 94$ & 267.0 & & \\
\hline $2 \mathrm{~N} 140$ & 251.8 & & \\
\hline \multicolumn{4}{|l|}{ Cultivars } \\
\hline H. Freya & 220.5 & 320.0 & 388.9 \\
\hline Ackerperle & 218.3 & 297.0 & 406.1 \\
\hline Aladin & 212.0 & 289.0 & 455.2 \\
\hline Erfordia & 156.1 & 174.0 & 441.0 \\
\hline Diana & 107.7 & 182.0 & 389.0 \\
\hline
\end{tabular}

*Values for 1 replication (20-25 plants) for the selections and the mean of 9 replication (35-40 plants/replication) for the licensed cultivars 
TABLE 4. Effect of fungicide seed treatments on the emergence of the faba bean cultivar Ackerperle in soil naturally infested with Aphanomyces euteiches and Rhizoctonia solani.

\begin{tabular}{|c|c|c|c|c|}
\hline \multirow[b]{2}{*}{ Fungicide } & \multirow{2}{*}{$\begin{array}{l}\text { Rate } \\
\% \text { ai }\end{array}$} & \multicolumn{2}{|c|}{ University of Manitoba ${ }^{+}$} & \multirow{2}{*}{$\frac{\text { East Manitoba }}{\text { May } 16}$} \\
\hline & & May 15 & June 15 & \\
\hline Control & 0 & 100.0 & 100.0 & 100.0 \\
\hline Delsene $40 \mathrm{~F}$ & .2 & 95.0 & 91.0 & 112.9 \\
\hline Terrachlor $75 \mathrm{~W}$ & .1 & 104.9 & 100.4 & 116.6 \\
\hline Demosan $65 \mathrm{~W}$ & .1 & 100.9 & 102.7 & 111.7 \\
\hline $\begin{array}{l}\text { Delsene } 40 \mathrm{~F}+ \\
\text { Terrachlor } 75 \mathrm{~W}\end{array}$ & .1 & 87.4 & 98.2 & 110.5 \\
\hline $\begin{array}{l}\text { De1sene } 40 \mathrm{~F}+ \\
\text { Demosan } 65 \mathrm{~W}\end{array}$ & .1 & 92.8 & 99.9 & 121.6 \\
\hline Ridomil 25 WP & .2 & 94.5 & 98.3 & 108.7 \\
\hline $\begin{array}{l}\text { Ridomil } 25 \text { WP }+ \\
\quad \text { CGA } 64251\end{array}$ & .02 & 94.4 & 101.4 & 121.4 \\
\hline DPX $1015 \mathrm{~F}$ & .1 & 96.5 & 94.6 & 112.1 \\
\hline Vitaflo $80 \mathrm{~W}$ & .1 & 98.6 & 101.5 & 116.3 \\
\hline & & NS & NS & NS \\
\hline
\end{tabular}

tValues represent the average of 9 replications.

Values were converted into \% of non-inoculated control. 
TABLE 5. Effect of fungicide seed treatments on the stand, disease severity index and fresh shoot weight of the cultivar Diana in soil natura11y infested with Aphanomyces euteiches and Rhizoctonia solani.

\begin{tabular}{|c|c|c|c|c|c|c|}
\hline \multirow[b]{2}{*}{ Fungicide } & \multirow{2}{*}{$\begin{array}{c}\text { Rate }(a i) \\
(\%)\end{array}$} & \multirow{2}{*}{$\begin{array}{l}\text { Emergence }{ }^{*} \\
(\% \text { contro } 1)\end{array}$} & \multicolumn{2}{|c|}{ 1st Rating +} & \multicolumn{2}{|c|}{ 2nd Rating } \\
\hline & & & DSI $(\%)$ & Fresh W: & $\operatorname{DSI}(\%)$ & Fresh W \\
\hline Contro1 & 0 & $100.0 \mathrm{a}$ & $58.45 \mathrm{~b}$ & $4.7 c^{* 2 *}$ & $61.47 \mathrm{c}$ & $10.6 \mathrm{a}$ \\
\hline Delsene $40 \mathrm{~F}$ & .2 & $109.8 \mathrm{a}$ & $57.30 \mathrm{~b}$ & $5.2 \mathrm{bc}$ & $60.50 \mathrm{c}$ & $10.7 \mathrm{a}$ \\
\hline Vitaflo $80 \mathrm{~W}$ & .1 & $116.8 \mathrm{a}$ & $53.66 \mathrm{~b}$ & $5.6 \mathrm{bc}$ & $56.74 \mathrm{bc}$ & $10.4 \mathrm{a}$ \\
\hline Terrazole S1. & .1 & $110.4 \mathrm{a}$ & $53.48 \mathrm{~b}$ & $5.4 \mathrm{bc}$ & $57.29 \mathrm{c}$ & 11.2 a \\
\hline Captan & .1 & $99.1 \mathrm{a}$ & $57.59 \mathrm{~b}$ & $4.9 \mathrm{bc}$ & $57.96 \mathrm{c}$ & $10.1 \mathrm{a}$ \\
\hline $\begin{array}{r}\text { Terrazole } \\
\text { acetone }\end{array}$ & .1 & $112.6 \mathrm{a}$ & $54.68 \mathrm{~b}$ & $4.7 \mathrm{c}$ & $59.55 \mathrm{c}$ & $10.4 \mathrm{a}$ \\
\hline Dowco $444 \mathrm{SI}$. & $.6 \mathrm{ml} / 10 \mathrm{~g}$ seed & $103.9 \mathrm{a}$ & $40.28 \mathrm{a}$ & $7.6 \mathrm{a}$ & $50.62 \mathrm{ab}$ & $13.4 \mathrm{a}$ \\
\hline Dowco 444 W.S. & $"$ & $118.6^{a}$ & $40.45 a$ & $6.8 \mathrm{ab}$ & $44.72 a$ & $11.7 \mathrm{a}$ \\
\hline Ridomil & .2 & 53.7 & - & - & - & - \\
\hline LSD .01 & & NS & 8.31 & 1.5 & 7.55 & NS \\
\hline
\end{tabular}

+ 1st date of rating, 5 weeks after planting; 2nd date of rating, 8 weeks after planting.

++ Fresh shoot weight/plant.

* Data represent average of 6 replications.

*** Treatments with same letters, in the same column, are not significantly different at $p=0.01$ (Duncan's Multiple Range Test). 


\section{DISCUSSION}

Yield losses, as well as losses in fresh shoot weight, were very high for all commercial cultivars tested, although losses in Herz Freya, Ackerperle and Aladin were significantly less than in Erfordia and Diana (Table 1). It is difficult to ascribe the losses to the pathogen only because soil analysis at the end of the season indicated that the soils of the infested and non-infested fields differed substantially in nitrogen content (29.0 vs $63.0 \mathrm{~kg} / \mathrm{ha}$, respectively). Growth of faba bean is not likely to be greatly influenced by soil nitrogen since plants from seeds inoculated with Rhizobium bacteria were found to nodulate well and fix large amounts of atmospheric nitrogen (Candlish and Clark, 1975). However, the root systems of infected plants were likely impaired or not functional. The yield and fresh shoot weight losses induced on the commercial cultivars in the field, in this study, do not appear to be excessively high compared to the fresh shoot weight losses in plants infected under greenhouse conditions (Thesis Section II) or to losses caused by $\underline{A}$. euteiches on peas in commercial fields (Papavizas and Ayers, 1974).

The variability in reaction to infection by $\underline{A}$. euteiches observed among the licensed cultivars (Table 1) was also found in the 350 faba bean accessions evaluated in the field. Although immunity was not observed, the tolerance and susceptibility of the plants were clearly expressed in the 1981 season, which was particularly favorable for Aphanomyces root rot because of high precipitation. Selection against 
root rot in 1980 was effective in identifying tolerance among the faba bean accessions. This is supported by the fact that $76 \%$ of the accessions selected in 1980 expressed tolerance to root rot in 1981 (Fig. IC), whereas only $37 \%$ of the accessions tested for the first time were found to be tolerant (Fig. 1). Furthermore, the yielding ability of four selected accessions was apparently not seriously affected by Aphanomyces root rot since they outyielded all the licensed cultivars (Table 5). The potential usefulness of the four tolerant accessions to a breeding program requires further evaluation.

The lack of significant differences between stands of all fungicides seed treatments and non-treated plots over two seasons of testing indicates that seed rot activity and pre-emergence damping-off were not important in spite of the fact that $\underline{\mathrm{R}}$. Solani was present in the experimental field plots at the $U$ of $M$. It is likely that the inoculum density of $\underline{R}$ solani in the field was low and/or that the most prevalent forms of this fungus were not pathogenic to faba bean seeds. This is supported by the fact that some isolates of the fungus were not able to infect and rot seeds of faba bean when tested in the greenhouse (Thesis Section I).

Partial control of Aphanomyces root rot was achieved for up to 5 weeks when seeds of the cultivar Diana were treated with Dowco 444. It is likely that the fungicide restricted the spread of the fungus within the host plant but did not prevent infection as indicated by the typical root discoloration and a DSI of $40 \%$ in the first rating (Table 5). Because Dowco 444 provided temporary control of Aphanomyces root rot in the field, the combined effect of the fungicide and host tolerance should be evaluated further under greenhouse and field conditions. 
GENERAL DISCUSSION

In this study, seedling blight and root rot of faba bean were found to be associated with Aphanomyces euteiches, Rhizoctonia solani and Fusarium sp. Pathogenicity tests showed that isolates of each fungal species were able to infect faba bean seedlings. Furthermore, symptoms induced singly by $\underline{A}$. euteiches and $\underline{R}$. solani may be similar, indicating that the disease cannot be attributed to either one of the pathogens on a visual basis only. It is, therefore, suggested that infected root tissue be observed microscopically for fungal structures to help select the appropriate method(s) for fungal isolation.

Interaction between the organisms associated with the root rot complex, in this study, has not been investigated. The very common presence of non- or low-pathogenic Fusarium spp. in infected roots in $U$ of $M$ experimental plots suggests that the relationship of these Fusarium sp. to faba bean root rot is more than coincidental and requires, therefore, further investigations. Available information seem to indicate that "minor" pathogens (i.e. unable to cause disease when inoculated alone) may be responsible for yield losses, and may also interact with other "minor" and "major" pathogens to influence disease development (Salt, 1979). A better understanding of the interactions of $\underline{A}$. euteiches, $\underline{R}$. solani and Fusarium sp. in the U of M fields is likely to facilitate the making of control measures for faba bean root rot. 
Several faba bean accessions were identified for their tolerance to the root rot complex in a field where $\underline{A}$. euteiches was the most important pathogen (Thesis Sections I and III). The scale used to score the aerial part of a whole plot of faba bean for disease has not been standardized with the scale used for rating roots, therefore, the tolerant selections should be evaluated further to ascertain the nature of the reaction. It would be desirable to be able to distinguish between low and high levels of tolerance based on the extent of root rot.

Greenhouse tests indicated that seedlings of the cultivars Ackerperle and PI 222128 became resistant to $\underline{A}$. euteiches as they reached 2 and 3 weeks, respectively (Thesis Section II). This suggests that greenhouse inoculation may be performed on 2-week-old seedlings in order to eliminate the most susceptible accessions.

Physiologic specialization in $\underline{A}$. euteiches was demonstrated in this study and has been previously reported (King and Bissonette, 1954; Sherwood and Hagedorn, 1962; Carlson, 1965; Beute and Lockwood, 1967; Sundheim, 1972; Reidings and Zettlers, 1973). The presence of different pathotypes (such as AEI and AE3) in the same field suggest that other pathotypes might still be recovered through screening of isolates from faba bean and other leguminous species. Whether pathotypes of $\underline{A}$. euteiches can anastomose and give rise to new recombinant forms is not known. As pointed out by Papavizas and Ayers (1974), this area of study is devoid of information, in spite of the fact that $A$. euteiches is known for more than 50 years and is still a limiting factor for pea cultivation in many regions.

Surveys of faba bean root pathogens in Manitoba, and particularly 
of A. euteiches, are needed to obtain information about the distribution of the fungus in the field pea and faba bean growing areas of Manitoba. Such information would also be helpful in preventing inoculum from building up to the destructive level observed at the $U$ of $M$ (Thesis Section III) Since efficient methods of direct recovery of A. euteiches from soil have not been devised, it is suggested that plants of susceptible faba bean (PI 222128) and peas (Little Marvel) be used as baits in laboratory, greenhouse or field tests. The rapid black discoloration of the root of faba bean in response to infection facilitates the early detection of disease and the isolation of $\underline{A}$. euteiches, as revealed in this study (Thesis Section II).

A partial control of Aphanomyces root rot of faba bean was achieved for up to 5 weeks through seed treatment with Dowco 444. The treatment did not, however, prevent infection of the seedlings by the fungus at an early stage. Since there are apparently no reports on the control of $\underline{A}$. euteiches with fungicide seed treatments in peas, it is suggested that further testing be carried out with chemicals such as Dowco 444 , particularly in combination with tolerance and dinitroaniline and trifluralin herbicides. These herbicides have been found to provide substantial control of the common root rot of pea by direct effect on the pathogen (Teasdale et al. 1979; Jacobsen and Hopen, 1981). 


\section{REFERENCES}

ABDALLAH, A.M. A-M. 1969. Studies on root rot diseases of broadbean in Egypt. M.Sc. Thesis, Fac. Agric., Ain Shams. In Abdallah, 1979.

ABDALLAH, M.M.F. 1979. The present status of field bean (Vicia faba L.) research in Egypt. A bibliographical report sponsored by ICARDA. Dept. of Agronomy, Cairo University, Egypt. (Abstracts)

ABD-EL-RAHIM, M.A. 1962. Studies on the organisms causing root rot and wilt of horse beans, Vicia faba var. equina in UAR. Ph.D. Thesis, Fac. Agric., Alexandria U. In Abdallah, 1979.

ALTMAN, J. 1972. Increased glucose exudate and damping-off in sugar beets in soils treated with herbicides. Phytopathology 62: 743.

ALTMAN, J. and CAMPBELL, C.L. 1977. Effects of herbicides on plant diseases. Ann. Rev. Phytopathology 15: 361-385.

ALTMAN, J. and ROSS, M. 1967. Unexpected preplant herbicide damage in sugar beets. Phytopathology 55: 1051.

ANONYMOUS. 1981. Faba bean production and use in Manitoba. Manitoba Dept of Agriculture pp. 20.

ANTONOPOULOS, A.A. 1969. Plant pathogen herbicide interactions, Ph.D. Diss., Colorado State Univ., Fort Collins, 216 pp. In Altman and Campbel1, 1977.

ALY, M.D. E-D. H. 1967. Studies on root rot disease of broad beans and its control in UAR Ph.D. Thesis, Fac. Agric., Ain Shams U. In Abdallah, 1979.

BARKSDALE, A.W. 1966. Segregation of sex in the progeny of a selfed heterozygote of Achlya bisexualis. Mycologia 58: 802-804.

BARKSDALE, A.W. 1968. Meiosis in the antheridium of Achlya ambisexualis E87. In "Mycological Studies Honoring John N. Couch", edited by W.J. Koch. Univ. of North Carolina Press, Chapel Hill, 280 ppi. pp. 187-194.

BARY, A. de. 1860. Einige neue Saprolegnieen. Jahrb. wiss. Bot. 2: 169-192. In Scott, 1961.

BERNIER, C.C. 1975. Diseases of pulse crops and their control. In "Oilseed and Pulse Crops in Western Canada", edited by J.T. Harapiak. A symposium: Western Co-operative Fertilizers Ltd., Calgary, Alta. pp. $439-454$. 
BEUTE, M.K. and LOCKWOOD, J.L. 1967. Pathogenic variability in Aphanomyces euteiches. Phytopathology 57: 57-60.

BHALIA, H.S. 1968. Number of zoospores of Aphanomyces euteiches required for infection on peas. (ABST) Phytopathology 58: 1043 .

BOND, D.A. 1979. Breeding work on Vicia faba in the U.K. Fabis Newsletter 1 : 5-6.

BOOSALIS, M.G. and SCHAREN, A.L. 1959. Methods for microscopic detection of Aphanomyces euteiches and Rhizoctonia solani and for isolation of Rhizoctonia solani associated with plant debris. Phytopathology 49: 192-198.

BOOTH, C. 1977. Fusarium. Laboratory guide to the identification of the major species. Commonwealth Mycological Institute. Kew, Surrey, England. pp. 58.

BRYAN, T.R. and HOWARD, K.L. 1969. Meiosis in the oomycetes: I. A microspectrophotometric analysis of nuclear deoxyribonwcleic acid in Saprolegnia terrestris. Amer. J. Bot. 56: 1075-1083.

BUCHHOLTZ, W.F. and MEREDITH, C.H. 1944. Pathogenesis of Aphanomyces cochlioides on tap roots of the sugar beet. Phytopathology 34 :

485-489.

BURKE, D.W., MITCHELL, I.E. and HAGEDORN, D.J. 1969. Selective conditions for infection of pea seedlings by Aphanomyces euteiches in soil. Phytopathology 59: 1670-1674.

BURPEE, L.L., SANDERS, P.L., COLE, H. and KIM, S.H. 1978. A staining technique for nuclei of Rhizoctonia solani and related fungi.

Mycologia 70: 1281-1283.

CANDLISH, E. and CLARK, K.W. 1975. Preliminary assessment of small faba beans grown in Manitoba. Can. J. Plant Sci. 55: 89-93.

CARLEY, H.E. 1969. Factors affecting the epidemiology of pea (Pisum sativum L.) root rot caused by Aphanomyces euteiches Drechs. Ph.D. Thesis, Minn. Univ., 120 pp. In Papavizas and Ayers, 1974.

CARLEY, H.E. 1970. Detection of Aphanomyces euteiches races using a differential bean series. P1. Dis. Reptr. 54: 943-945.

CARLSON, L.E. 1965. Studies on the root rot of peas caused by Aphanomyces euteiches Drechs. Ph.D. Thesis, Minn. Univ.

CARLSON, W.C. and HOPER, H.J. 1971. The effect of six herbicides on root rots in seedling vegetable legumes. Proc. Cent. Weed Control Conf. 25: 79 .

CHO, Y.S. and KING, T.H. 1963. Factors affecting infection and oospore formation of Aphanomyces euteiches Drechs, in excised root tip of Pisum sativum. Minn. Acad. Sci. Proc. 30: 123-127. 
COKER, W.C. 1923. The Saprolegniaceae with notes on other water molds. N.C. Univ. Press, Chapel Hil1, 201 pp.

CONNERS, I.L. 1967. An annotated index of plant diseases in Canada. Pub1. No. 1251, Can. Dept. Agric. Res. Branch, Ottawa. 205 pp.

COULOMBE, L.J. 1957. Le fletrissement fusarien des gourganes. Rep. Quebec Soc. Prot. 38 (1956): 26-33. In Review of Applied Mycology 37: 434 .

CUBERO, J.I. 1974. On the evolution of Vicia faba L. Theor. App1. Genetics 45: 47-51.

CUBERO, J.I. 1979. Vicia faba in Spain. Fabis Newsletter 1: 10-11.

CUNNINGHAM, J.L. and HAGEDORN, D.J. 1962a. Attraction of Aphanomyces euteiches zoospores to pea and other plant roots. Phytopathology 52: $616-618$.

CUNNINGHAM, J.L. and HAGEDORN, D.J. 1962b. Penetration and infection of pea roots by zoospores of Aphanomyces euteiches. Phytopathology 52: $827-834$.

DORAN, W.L., GUBA, E.F. and GILGUT, C.G. 1542. The control of dampingoff of vegetables by formaldehyde and other chemicals. Mass. Agr。 Exp. Stat. Bull. 394, 20 pp.

DRECHSLER, C. 1929. The beet water mold and several related root parasites. J. Agr. Research 38: 309-361.

DRECHSLER, C. 1935. Occurrence of a species of Aphanomyces on roots of spinach and flax. Phytopathology 25: 14-15.

DRECHSLER, C. 1954. A. euteiches from pea roots and "Aphanomyces euteiches PF2". Wash. Acad. Sci. Journal 44: 236-244.

DUNIN, M.S. 1962. Methods of protecting fodder beans from diseases. Izvestiya, Timiryazev Sel. Akad. 1962, 11-31. English Summary in Review of Applied Mycology 42: 64.

ELIASON, E.J. 1928. Comparative virulence of certain strains of Pythium in direct inoculation of conifers. Phytopathology 18: 361-367.

EVANS, L.E., SEITZER, J.F. and BUSHUK, W. 1972. Horsebeans - a protein crop for Western Canada? Can. J. P1ant Sci. 52: 657-659.

EVANS, L.E. and SLINKARD, A.E. 1975. Production of pulse crops in Canada. In "Oilseed and Pulse Crops in Western Canada", edited by J.T. Harapiak. A symposium: Western Co-operative Fertilizers Ltd., Calgary, Alta. pp. 287-324.

FINK, H.C. 1948. Correlation between sugar beet crop losses and greenhouse determinations of soil infestations by Aphanomyces cochliades. (ABST) Phytopathology 38: 9. 
FINK, H.C. and BUCHHOLTZ, W.F. 1954. Correlation between sugar beet crop losses and greenhouse determinations of soil infestation by Aphanomyces cochlioides. Amer. Soc. Sugar Beet Technol. Proc. 8: 252259. In Papavizas and Ayers, 1974.

GEACH, W.L. 1936. Root rot of grey peas in Tasmania. Austral. Council Sci. and Indus. Res. Jour. 9: 77-87. In Papavizas and Ayers, 1974.

GRAU, C.R. 1977. Effect of dinitramine and trifluralin on growth, reproduction and infectivity of Aphanomyces euteiches. Phytopathology 67: $551-556$.

GRAU, C.R. and REILING, T.P. 1977. Effect of trifluralin and dinitramine on Aphanomyces root rot of pea. Phytopathology 67: 273-276.

HAENSLER, C.M. 1926. Studies on the root rot of peas (Pisum sativum) caused by Aphanomyces euteiches Drechsler. N.J. Agr. Expt. Sta. Ann. Rept. 46: 467-484, illus.

HAGLUND, W.A. and KING, T.H. 1961. Inoculation technique for determining tolerance of Pisum sativum to $\underline{A}$. euteiches. Phytopathology 51: $800-802$.

HAGLUND, W.A. 1968. Chemical control of pea root rot by soil:

Incorporation and in-furrow treatments with 1-chloro-2-nitropropane. U.S. Dept. Agr. Plant Dis. Rept. 52: 72-75.

HARVEY, R.G., HAGEDORN, D.J. and DELONGHENY, R.L. 1975. Influence of herbicides on root rot in processing peas. Crop Sci. 15: 67-71.

HAWTIN, G. and STEWART, R. 1979. The development, production and problems of faba beans (Vicia faba) in Western Asia and North Africa. Fabis Newsletter $\underline{1}$ : 7-9.

IBRAHIM, I.A. and ABDEL REHIM, M.A. 1965. Fusarium root rot and wilt on horse bean (Vicia faba var. equina) in U.A.R. Alexandria Journal of Agricultural Research 13: 415-426. In Salt, 1981.

IBRAHIM, G. and HUSSEIN, M.M. 1974. A new record of root rot of broad bean (Vicia faba) from the Sudan. J. Agric. Sci. 83: 381-383.

IKATA, S. 1951. The disease of food crops. No. 1: Rice plants and beans. Asakura Shoten Tokyo. English summary in Review of Applied Mycology 31: 458 (1952).

JACOBSEN, B.J. and HOPEN, H.J. 1981. Influence of herbicides on Aphanomyces root rot of peas. Plant Disease 65: 11-16.

JOHNSON, H.G. 1953. Investigations on the control of root rot of peas. Ph.D. Thesis, Minn. Univ. In Papavizas and Ayers, 1974.

JOHNSON, H.G. 1957. A method for determining the degree infestation by pea root rot organisms in soil. Phytopathology 47(1): 18. (ABST) 
JONES, F.R. 1926. Resistance of peas to root rot. Phytopathology 16: $459-465$.

JONES, F.R. and DRECHSLER, C. 1925. Root rot of peas in the United States caused by Aphanomyces euteiches. J. Agr. Res. 30: 293-325.

KING, T.H. and BISSONNETTE, H.L. 1954. Physiologic specialization in Aphanomyces euteiches (Abst). Phytopathology 44: 495.

KING, T.H., BISSONNETTE, H.L. and JOHNSON, H.G. 1957. Status of studies on developing lines of Pisum sativum resistant or tolerant to Fusarium root rot (Abst). Phytopathology 47: 20.

KING, T.H. and CHO, Y.S. 1962. Oospore formation of Aphanomyces euteiches in root tips of Pisum sativum as a method of evaluating resistance. P1. Dis. Reptr. 46: 777-779.

KO, W.H. and HORA, F.K. 1971. A selective medium for the quantitative determination of Rhizoctonia solani in soil. Phytopathology 61: 707710.

LINFORD, M.B. 1927. Additional host of Aphanomyces euteiches (ABST). Phytopathology 17: 133-134.

LINFORD, M.B. 1928. A Fusarium wilt of peas in Wisconsin. Wisconsin Agric. Exp. Stat. Res. Bull. 851. In Schneider and Dalchow, 1975.

LINFORD, M.B. and VAUGHAN, R.E. 1925. Root rot of peas. Some ways to avoid it. Wis. Agr. Col. Ext. Serv. Cir. 188, 11 pp. In Papavizas and Ayers.

LIANOS, M.C. and LOCKWOOD, J.L. 1960. Factors affecting zoospore production by Aphanomyces euteiches. Phytopathology 50: 826-830.

LOCKWOOD, J.L. 1960a. Pea introductions with partial resistance to Aphanomyces root rot. Phytopathology 50: 621-624.

LOCKWOOD, J.L. 1960b. Progress and problems in breeding peas res istant to root rots. Mich. Agr. Expt. Stat. Quart. Bul1. 43: 358-366.

LOCKWOOD, J.L. 1960c. Lysis of mycelium of plant pathogenic fungi by natural soil. Phytopathology 50: 787-789.

LOCKWOOD, J.L. and BALIARD, J.C. 1959. Factors affecting a seedling test for evaluating resistance of pea to Aphanomyces root rot. Phy topathology 49 : 406-410.

LU, J. and THIBODEAU, P. 1978. Les maladies de la féverole au Québec. Science et Technique.Conseil des Productions vegetales du Quebec 25: $7 \mathrm{pp}$.

MACWITHEY, H.S. 1965. Factors affecting the prevalence of black root disease of sugar beets (ABST). Phytopathology 55: 887. 
MARCHAL, E. and VERPLANCKE, G. 1926. Champignons parasites nouveaux pour la flore belge observes de 1919-1925. Bull. Soc. Roy. Bot.

Belg. 59: 19-25. In Schneider and Dalchow, 1975.

MARX, G.A., SCHROEDER, W.T., PROVIDENTI, R. and MISHANEC, W. 1972. A genetic study of tolerance in pea to Aphanomyces euteiches. Amer. Soc. Hort. Sci. J. 97(5): 619-621.

MCEWEN, J., SALT, G.A. and HORNBY, D. 1973. The effects of dazomet and fertilizer nitrogen on field beans (Vicia faba L.). J. Agric. Sci. Camb. 80: 105-110.

MCEWEN, J. and OTHERS: 1981. The effects of irrigation, nitrogen fertilizer and the control of pests and pathogens on spring-sown field beans (Vicia faba L.) and residual effects on two following winter wheat crops. J. Agric. Sci. Camb。 96: 129-150.

MC KEEN, C.D. 1952. Aphanomyces cladogamus Drechs., a cause of damping-off in pepper and certain other vegetables. Can. J. Bot. 30: $701-709$.

MEURS, A. 1929. Root rot caused by fungi of the genera Pythium Pringsheim and Aphanomyces de Bary. Rev. App1. Myco1. 8: $187-188$.

MITCHELL, J.E., BHALLA, H.S. and YANG, G.H. 1969. An approach to the study of the population dynamics of Aphanomyces euteiches in soil. Phytopathology 59: 206-212.

MITCHELL, J.E. and HAGEDORN, D.J. 1971. Residual Dexon and the persistent effect of soil treatments for control of pea root rot caused by Aphanomyces euteiches. Phytopathology 61: 978-983.

MIX, A.J. 1945. Aphanomyces root rot of lettuce, pepper and eggplant seedlings in Northern New Jersey. Plant Disease Reptr. 29: 649-650.

MORRISON, R.H., JOHNSON, J.K., KING, T.H. and DAVIS, D. 1971。 An evaluation of the excised root tip method for determining the resistance of Pisum sativum to Aphanomyces euteiches. J. Amer. Hort. Sci. $\underline{96}(5): 616-619$.

NASH, S.M. and SNYDER, W.C. 1962. Quantitative estimations by plate counts of propagules of the bean root rot Fusarium in the field soils. Phytopathology 52: 567-572.

PAPAVIZAS, G.C. and AYERS, W.A. 1974. Aphanomyces species and their root diseases in pea and sugar beet. USDA Tech. Bu11. 1485, 158 pp.

PARMETER, J.R. and WHITNEY, H.S. 1970。 Taxonomy and nomenclature of the imperfect state. In "Rhizoctonia solani: Biology and Pathology, edited by J.R. Parmeter, Jr. Univ. California Press, Berkeley, 7-19 pp.

PFENDER, W.F. and HAGEDORN, D.J. 1981. Aphanomyces root and stem rot of snap beans (ABST). Phytopathology 71: 250 . 
PLATFORD, R.G. and BERNIER, C.C. 1973. Diseases of faba beans in Manitoba. Proc. Man. Agron. Conf. pp. 92-93. In Bernier, 1975.

POULSEN, M.H. 1975. Pollination, seed setting, cross fertilization and inbreeding in Vicia faba L. Z. Pfanzenzuchtg. 74: 97-118.

REILING, T.P., KING. T.H. and FIELDS, R.W. 1960. Soil indexing for pea root rot and the effect of root rot on yield. Phytopathology 50: $287-290$.

REINKING, O.A. 1942. Distribution and relative importance of various fungi associated with pea root rot in commercial pea-growing areas in New York. N.Y. (Corne11) Agr. Expt. Sta. Tech. Bu11. 264, 43 pp.

REINKING, O.A. and NEWHALL, A.G. 1950. A soil fumigation test for pea root rot control. Phytopathology 40: 879-882.

RIDINGS, W.H. and ZETTLER, F.W. 1973. Aphanomyces blight of Amazon Sword plants. Phytopathology 63: 289-295.

ROMING, W.R. and SASSER, M. 1972. Herbicide predisposition of snap beans to Rhizoctonia solani. Phytopathology 62: 785-786. (ABST)

SACHER, R.F., HOPEN, H.J. and JACOBSEN, B. 1978. Suppression of root diseases and weeds in peas (Pisum sativum) treated with dinitrophenol and dinitroaniline herbicide. We d Sci. 26: 589-593.

SALT, G.A. 1979. Minor pathogens

In "Soil-borne pathogens", edited by B. Schippers and W. Gams. An International Symposium. Ac. Press.

SALT, G.A. 1981. Factors affecting resistance to root rot and wilt diseases. International Conference on Faba Beans. Cairo 7-11 March, pp. 18.

SALT, G.A. and HORNBY, D. 1971a. Rept. Rothamsted Expt. Stn. for 1970, Pt. 1, pp. 136-137.

SALT, G.A. and HORNBY, D. 1971b. Root rot and wilt of field beans (Vicia faba). Proc. 6th Br. Insectic. Fungic. Conf. pp. 251-257.

SANSOME, E. 1961. Meiosis in the oogonium and antheridium of Pythium debaryanum Hesse. Nature 191: 827-828.

SANSOME, E. 1962. Meiosis in Pythium debaryanum Hesse. and its significance in the life history of the Biflagellatae. Trans. Brit. Mycol. Soc. 46: 63-72.

SANSOME, E. 1965. Meiosis in diploid and polyploid sex organs of Phytophthora and Achlya. Cytologia 30: 103-117.

SCHAREN, A.L. 1960. Germination of oospores of Aphanomyces euteiches embedded in plant debris. Phytopathology 50: 274-277. 
SCHMITTHENNER, A.F. 1964. Prevalence and virulence of Phytophthora, Aphanomyces, Pythium, Rhizoctonia and Fusarium isolated from diseased alfalfa seedlings. Phytopathology 54: 1012-1018.

SCHNEIDER, R, and DALCHOW, J. 1975. Fusarium inflexum spec. nov., als Erreger einer Welkekrankheit an Vicia faba $\mathrm{L}$. in Deutschland. Phytopathologie. Z. 82 : 70-82.

SCHNEIDER, C.I. 1956. Studies on the pathogenicity and host range of the sugar beet black root fungus, Aphanomyces cochlioides Drechs. Ph.D. Thesis, Minn. Univ., 103 pp. In Papavizas and Ayers, 1974.

SCHULTZE-MOTEL, J. Von. 1972. Die archaologischen Resten der Ackerbohne Vicia faba und die Genase der Art*. Kulturpflanze 19: 321-358. In Hawtin and Stewart, 1979.

SCOTT, W.W. 1961. A monograph of the genus Aphanomyces. Va. Agr. Expt. Sta. Tech. Bul1. 151, 95 pp.

SHEHATA, M.A., DAVIS, D.W. and BISSONNETTE, H.L. 1976. A new testing approach for breeding peas resistant to common root rot caused by Aphanomyces euteiches Drechs. J. Amer. Hort. Sci. 101: 257-261.

SHERWOOD, R.T. 1958. Aphanomyces root rot of garden pea. Ph.D. Thesis, Wisc. Univ., 119 pp. In Papavizas and Ayers, 1974.

SHERWOOD, R.T. and HAGEDORN, D.J. 1958. Determining the common root rot potential of pea fields. Wisconsin Agric. Exp. Stn. Bul1. 531, $12 \mathrm{pp}$.

SHERWOOD, R.T. and HAGEDORN, D.J. 1962. Studies on the biology of Aphanomyces euteiches. Phytopathology 52: 150-154.

SMITH, P.G. and WALKER, J.C. 1941. Certain environmental factors affecting Aphanomyces root rot of garden peas. J. Agr。Res. 63: 1-20.

SPARROW, F.K. 1960. Aquatic Phycomycetes. University of Michigan Press, pp. 843-844.

SUNDHEIM, L. 1972. Physiologic specialization in Aphanomyces euteiches. Physiological Plant Pathology 2: 301-306.

TEASDALE, J.R., HARVEY, R.G. and HAGEDORN, D.J. 1979. Mechanism for the suppression of pea (Pisum sativum) root rot by dinitroaniline herbicides. Weed Sci. 27: 195-201.

TEMP, M.W. 1966. Field and laboratory investigations with Aphanomyces euteiches. Ph.D. Thesis, Wisc. Univ., $141 \mathrm{pp}$.

TRAQUAIR, J.A. and MCKEEN, M.E. 1980. Electron microscopy of developing Aphanomyces oogonia and oospores. Mycologia 72: 378-394.

VAN EEK, T. 1938. Root rot of Viola tricolor maxima. Hort. Phytopath. Zeitschr. 11: 217-281. In Drechsler, 1954. 
YAMAMOTO, W., OYASU, N. and TARIGAWA, K. 1955. Studies on the wilt disease of broad bean. I. Sci. Rep. Hyogo Univ. Agric. 2: 53-62. In Schneider and Dalchow, 1975.

YU, T.F. 1944. Fusarium diseases of broad beans. I. A wilt of broad bean caused by Fusarium avenaceum var. fabae n. var. Phytopathology 34: 385-393.

YU, T.F. and FANG, C.T. 1948. Fusarium diseases of broad beans caused by two new forms of Fusarium. Pnytopathology 38: 587-594.

ZOHARY, D. and HOPF, M. 1973. Domestication of pulses in the 01d World. Science 182: 887-894.

* Other= BARDNER, R., BRIgGS G.G., BROMIlOW R.H., COCKBAIN A.J., DAY J.M., FLETCHER K.E., LEGG B.J., ROUGHLEY R.G., SALT S.A., SIMPSON H.R., WEBB R.M., WITTY J.F., and YEOMAN D.P. 
APPENDIX 1. Peptone PCNB medium for isolation of Fusarium sp. (Nash and Snyder, 1962)

$\begin{array}{lr}\text { Difco peptone } & 15.0 \mathrm{~g} \\ \text { Agar } & 20.0 \mathrm{~g} \\ \mathrm{KH}_{2} \mathrm{PO}_{4} & 1.0 \mathrm{~g} \\ \mathrm{MgSO}_{4} \cdot 7 \mathrm{H}_{2} \mathrm{O} & 0.5 \mathrm{~g} \\ \text { Pentachloronitrobenzene (PCNB) } & 1.0 \mathrm{~g} \\ \text { Streptomycin } & 300 \mathrm{ppm}\end{array}$

APPENDIX 2. Selective Medium for Rhizoctonia solani (Ko and Hora, 1971).

$\begin{array}{lr}\mathrm{K}_{2} \mathrm{HPO}_{4} & 1.0 \mathrm{~g} \\ \mathrm{MgSO}_{4} \cdot 7 \mathrm{H}_{2} \mathrm{O} & 0.5 \mathrm{~g} \\ \mathrm{KCl} & 0.5 \mathrm{~g} \\ \mathrm{FeSO}_{4} \cdot 7 \mathrm{H}_{2} \mathrm{O} & 10.0 \mathrm{mg} \\ \mathrm{NaNO}_{2} & 0.2 \mathrm{~g} \\ \mathrm{Gallic}^{2} \text { acid } & 0.4 \mathrm{~g} \\ \text { Dexon } & 90.0 \mathrm{mg} \\ \text { Chloramphenicol } & 50.0 \mathrm{mg} \\ \text { Streptomycin } & 50.0 \mathrm{mg} \\ \text { Agar } & 20.0 \mathrm{~g} \\ \text { Water (distilled) } & 1.01\end{array}$


APPENDIX 3. Procedure followed for the production of zoospores by Aphanomyces euteiches.

1- Inoculate $2 \%$ water agar plate with mycelium of $\underline{A}$. euteiches.

2- Flood the agar with maltose (3\%) peptone (1\%) broth.

3- Incubate at room temperature $\left(22^{\circ} \mathrm{C}\right)$ for $4-5$ days.

4- Remove broth and wash with tap water twice, then cover the mycelium with tap water for 1-2 hours.

5- Replace tap water with distilled water and check after 6 hours.

APPENDIX 4. Staining procedure used in the identification of Rhizoctonia

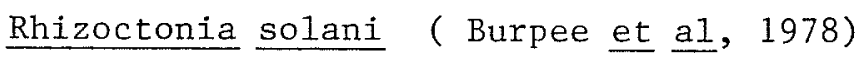

1- The fungus is grown on PDA for 4 days.

2- 7-mm mycelial plugs are cut from the edge and transfered to the center of Petri dishes containing $1.5 \%$ water agar.

3- When culture at ca. $1 \mathrm{~cm}$ from the edge of water agar plate, a drop of either .5\% aniline blue or trypan blue is placed directly on the mycelium midway between the center and the edge of the culture.

APPENDIX 5. Procedure followed for soil sampling and testing for the presence of Aphanomyces euteiches (Sherwood and Hagedorn, 1958).

1- Collecting soil samples.

+ walking in ziz-zag course

+ Every 55-75 paces a trowelful of soil is taken to a depth of ca. $15 \mathrm{~cm}$ and placed in a polyethylene bag.

2- Testing in the greenhouse.

+ Soil dispensed in pots and planted with seeds of a susceptible pea (replaced by faba bean in this study).

+ Soil kept normally moist until 2 first leaves fully expanded, then soil held near saturation. 
APPENDIX 6. Reaction of faba bean accessions to Aphanomyces root rot in 1980 in field 非 18 at the $U$ of $M$ campus farm.

\section{1 - No apparent symptoms}

$2 \mathrm{~N} 43,2 \mathrm{~N} 296,2 \mathrm{~N} 101,2 \mathrm{~N} 23,2 \mathrm{~N} 15,2 \mathrm{~N} 19,2 \mathrm{~N} 20,2 \mathrm{~N} 98,2 \mathrm{~N} 342,2 \mathrm{~N} 10,2 \mathrm{~N} 134$, $2 \mathrm{~N} 240,2 \mathrm{~N} 37,2 \mathrm{~N} 428,2 \mathrm{~N} 26,2 \mathrm{~N} 109,2 \mathrm{~N} 121,2 \mathrm{~N} 96,2 \mathrm{~N} 63,2 \mathrm{~N} 242,2 \mathrm{~N} 21,2 \mathrm{~N} 236$, $2 \mathrm{~N} 411,2 \mathrm{~N} 18,2 \mathrm{~N} 94,2 \mathrm{~N} 112,2 \mathrm{~N} 113,2 \mathrm{~N} 114,2 \mathrm{~N} 239,2 \mathrm{~N} 123,1,12,13,16$, 18, 2N2, 2N18, 2N11, Ackerperle, Herz Freya.

2 - Normal growth but yellowing of lower leaves

$2 \mathrm{~N} 122,2 \mathrm{~N} 396,2 \mathrm{~N} 124,2 \mathrm{~N} 297,2 \mathrm{N5}, 2 \mathrm{~N} 138, \mathrm{FIDRIN}, 2 \mathrm{~N} 73,2 \mathrm{~N} 245,2 \mathrm{~N} 3,2 \mathrm{~N} 12$, $2 \mathrm{~N} 41,2 \mathrm{~N} 6,2 \mathrm{~N} 119,2 \mathrm{~N} 382,2 \mathrm{~N} 304,2 \mathrm{N1}, 2 \mathrm{~N} 398,2 \mathrm{~N} 263,2 \mathrm{~N} 235,2 \mathrm{~N} 8,2 \mathrm{~N} 109$, $2 \mathrm{~N} 189,2 \mathrm{~N} 333,2 \mathrm{~N} 435,2 \mathrm{~N} 436,2 \mathrm{~N} 100,2 \mathrm{~N} 340,2 \mathrm{~N} 80,2 \mathrm{~N} 382,2 \mathrm{~N} 218,5,6,7$, $2 \mathrm{~N} 9,2 \mathrm{~N} 69,2 \mathrm{~N} 67,2 \mathrm{~N} 121,2 \mathrm{~N} 70$.

\section{3 - Stunting and extensive yellowing}

$2 \mathrm{~N} 246,2 \mathrm{~N} 46,2 \mathrm{~N} 402,2 \mathrm{~N} 405,2 \mathrm{~N} 313,2 \mathrm{~N} 452,2 \mathrm{~N} 42,2 \mathrm{~N} 34,2 \mathrm{~N} 133,2 \mathrm{~N} 419,2 \mathrm{~N} 238$, 2N204, 2N432, 2N429, 2N396, 2N209, 2N424, 2N124, 2N408, 2N294, 2N320, 2N369, 2N412, 2N247, 2N407, 2N13, 2N38, 2N391, Diana, Erfordia, Triple white.

$$
4 \text { - Very pronounced stunting and most plants dead }
$$

$2 \mathrm{~N} 256^{*}, 2 \mathrm{~N} 448,2 \mathrm{~N} 410,2 \mathrm{~N} 456^{*}, 2 \mathrm{~N} 260,2 \mathrm{~N} 262,2 \mathrm{~N} 228,2 \mathrm{~N} 358,2 \mathrm{~N} 451,2 \mathrm{~N} 447$, $2 \mathrm{~N} 296,2 \mathrm{~N} 455,2 \mathrm{~N} 302,2 \mathrm{~N} 424,2 \mathrm{~N} 265,2 \mathrm{~N} 264,2 \mathrm{~N} 399,2 \mathrm{~N} 328,2 \mathrm{~N} 429,2 \mathrm{~N} 257$, $2 \mathrm{~N} 367,2 \mathrm{~N} 406,2 \mathrm{~N} 413,2 \mathrm{~N} 423^{*}, 2 \mathrm{~N} 402^{*}, 2 \mathrm{~N} 411^{*}, 2 \mathrm{~N} 266,2 \mathrm{~N} 421^{*}, 2 \mathrm{~N} 405,2 \mathrm{~N} 246$, $2 \mathrm{~N} 378,2 \mathrm{~N} 250,2 \mathrm{~N} 418,2 \mathrm{~N} 452,2 \mathrm{~N} 409,2 \mathrm{~N} 426,2 \mathrm{~N} 433,2 \mathrm{~N} 440,2 \mathrm{~N} 431,2 \mathrm{~N} 450$, Kodrin, PI 222128.

\footnotetext{
*Accessions which did not survive more than 4 weeks after planting.
} 
APPENDIX 7. Reaction of faba bean accessions to Aphanomyces root rot in 1981 in field $k_{18} 18$ at the $U$ of M campus farm.

1 - No apparent symptoms

$2 \mathrm{~N} 22,2 \mathrm{~N} 26,2 \mathrm{~N} 32,2 \mathrm{~N} 37,2 \mathrm{~N} 54,2 \mathrm{~N} 58,2 \mathrm{~N} 62,2 \mathrm{~N} 71,2 \mathrm{~N} 74,2 \mathrm{~N} 83,2 \mathrm{~N} 97,2 \mathrm{~N} 106$, $2 \mathrm{~N} 138,2 \mathrm{~N} 196,2 \mathrm{~N} 217,2 \mathrm{~N} 229,2 \mathrm{~N} 346(?), 2 \mathrm{~N} 355,2 \mathrm{~N} 371,2 \mathrm{~N} 475,2 \mathrm{~N} 478,2 \mathrm{~N} 480$, $2 \mathrm{~N} 486,2 \mathrm{~N} 487,2 \mathrm{~N} 509,2 \mathrm{~N} 511,2 \mathrm{~N} 517,2 \mathrm{~N} 518,2 \mathrm{~N} 519,2 \mathrm{~N} 520,2 \mathrm{~N} 522,2 \mathrm{~N} 523$, $2 \mathrm{~N} 534$.

2 - Normal growth but premature yellowing of the lower leaves $2 \mathrm{~N} 44,2 \mathrm{~N} 45,2 \mathrm{~N} 53,2 \mathrm{~N} 59,2 \mathrm{~N} 65,2 \mathrm{~N} 76,2 \mathrm{~N} 82,2 \mathrm{~N} 96,2 \mathrm{~N} 110,2 \mathrm{~N} 111,2 \mathrm{~N} 134(?)$, $2 \mathrm{~N} 141,2 \mathrm{~N} 148,2 \mathrm{~N} 155,2 \mathrm{~N} 195,2 \mathrm{~N} 197,2 \mathrm{~N} 218,2 \mathrm{~N} 219,2 \mathrm{~N} 227,2 \mathrm{~N} 43,2 \mathrm{~N} 295$, $2 \mathrm{~N} 297,2 \mathrm{~N} 321,2 \mathrm{~N} 392,2 \mathrm{~N} 425,2 \mathrm{~N} 470,2 \mathrm{~N} 477,2 \mathrm{~N} 482,2 \mathrm{~N} 483,2 \mathrm{~N} 485,2 \mathrm{~N} 489$, 2N502, 2N506, 2N507, 2N508, 2N510, 2N516, 2N526, 2N527, 2N529.

3 - Stunting and extensive yellowing of the foliage 2N14, 2N34, 2N52, 2N72, 2N78, 2N89, 2N117, 2N200, 2N202, 2N203, 2N215, $2 \mathrm{~N} 220,2 \mathrm{~N} 232,2 \mathrm{~N} 237,2 \mathrm{~N} 244,2 \mathrm{~N} 252,2 \mathrm{~N} 288,2 \mathrm{~N} 291,2 \mathrm{~N} 299,2 \mathrm{~N} 307,2 \mathrm{~N} 311$, 2N312, 2N319, 2N331, 2N343, 2N368, 2N377, 2N404, 2N437, 2N467, 2N479, $2 N 488,2 N 491,2 N 493,2 N 497,2 N 499,2 N 504,2 N 514,2 N 513,2 N 524,2 N 530$, $2 \mathrm{~N} 531$.

4 - Very pronounced stunting and most plants dead $2 \mathrm{~N} 4,2 \mathrm{~N} 29^{*}, 2 \mathrm{~N} 35^{*}, 2 \mathrm{~N} 47,2 \mathrm{~N} 50,2 \mathrm{~N} 57,2 \mathrm{~N} 67,2 \mathrm{~N} 84,2 \mathrm{~N} 85^{*}, 2 \mathrm{~N} 86,2 \mathrm{~N} 91^{*}$, $2 \mathrm{~N} 94,2 \mathrm{~N} 156,2 \mathrm{~N} 177,2 \mathrm{~N} 206^{*}, 2 \mathrm{~N} 211,2 \mathrm{~N} 221,2 \mathrm{~N} 222^{*}, 2 \mathrm{~N} 223,2 \mathrm{~N} 24^{*}, 2 \mathrm{~N} 233^{*}$, $2 \mathrm{~N} 248,2 \mathrm{~N} 250,2 \mathrm{~N} 272^{*}, 2 \mathrm{~N} 276,2 \mathrm{~N} 277^{*}, 2 \mathrm{~N} 278,2 \mathrm{~N} 284^{*}, 2 \mathrm{~N} 286^{*}, 2 \mathrm{~N} 292^{*}$, $2 \mathrm{~N} 293,2 \mathrm{~N} 303^{*}, 2 \mathrm{~N} 316,2 \mathrm{~N} 317,2 \mathrm{~N} 318^{*}, 2 \mathrm{~N} 322,2 \mathrm{~N} 323,2 \mathrm{~N} 326,2 \mathrm{~N} 334,2 \mathrm{~N} 335^{*}$, $2 \mathrm{~N} 337^{*}, 2 \mathrm{~N} 345^{*}, 2 \mathrm{~N} 348,2 \mathrm{~N} 351^{*}, 2 \mathrm{~N} 352^{*}, 2 \mathrm{~N} 353,2 \mathrm{~N} 354^{*}, 2 \mathrm{~N} 356^{*}, 2 \mathrm{~N} 357^{*}$, $2 \mathrm{~N} 370,2 \mathrm{~N} 372^{*}, 2 \mathrm{~N} 381,2 \mathrm{~N} 384^{*}, 2 \mathrm{~N} 390^{*}, 2 \mathrm{~N} 394(?), 2 \mathrm{~N} 408,2 \mathrm{~N} 412^{*}, 2 \mathrm{~N} 414$, $2 \mathrm{~N} 416,2 \mathrm{~N} 422,2 \mathrm{~N} 431,2 \mathrm{~N} 434^{*}, 2 \mathrm{~N} 444,2 \mathrm{~N} 450^{*}, 2 \mathrm{~N} 451,2 \mathrm{~N} 465,2 \mathrm{~N} 469,2 \mathrm{~N} 471^{*}$, $2 \mathrm{~N} 472^{*}, 2 \mathrm{~N} 473,2 \mathrm{~N} 474,2 \mathrm{~N} 484^{*}, 2 \mathrm{~N} 490^{*}, 2 \mathrm{~N} 492^{*}, 2 \mathrm{~N} 494(?), 2 \mathrm{~N} 496(?), 2 \mathrm{~N} 503^{*}$, $2 \mathrm{~N} 505,2 \mathrm{~N} 513,2 \mathrm{~N} 521,2 \mathrm{~N} 533^{*}$.

* Accessions which did not survive more than 4 weeks after planting. 
APPENDIX 8. Disease score of 38 accessions selected in 1980 and tested in 1981 .

\begin{tabular}{|c|c|c|c|c|c|}
\hline & I & II & III & Final & Score ${ }^{* *}$ \\
\hline $2 \mathrm{~N} 62$ & $4 / 1$ & $3-4 / 2$ & $2-3 / 1$ & & 2 \\
\hline IZ (Diana 76-8) & $4 / 1$ & $4 / 2$ & $4 / 1$ & & 2 \\
\hline IS (DN75-25 ERF) & $4 / 3$ & $3 / 1$ & $4 / 3$ & & 3 \\
\hline B118 & $4 / 3$ & $4 / 3$ & $4 / 2$ (Stunted) & & 3 \\
\hline$*$ I4 (DN76-8 SPS) & $1 / 1$ & $4 / 1$ & 4/ (3 plants) & & 1 \\
\hline *I12 (DN75-38 ERF) & $4 / 1$ & $3-4 / 1$ & - & & 1 \\
\hline Diana & $4 / 3$ & $3 / 1$ & - & & 3 \\
\hline$* 2 \mathrm{~N} 116$ & $4 / 1$ & $4 / 1$ & $3 / 1$ & & 1 \\
\hline$* 2 \mathrm{~N} 68$ & $4 / 1$ & $4 / 1$ & - & & 1 \\
\hline $2 \mathrm{~N} 120$ & $4 / 2$ & $4 / 3$ & - & & 3 \\
\hline$* 2 N 140$ & $4 / 1$ & $4 / 1$ & $3 / 1$ & & 1 \\
\hline $2 \mathrm{~N} 101$ & $3 / 2$ & $4 / 3$ & $4 / ?$ & & 3 \\
\hline $2 \mathrm{~N} 342$ & $3 / 2$ & $4 / 4$ & $4 / 1-2$ & & 4 \\
\hline$\approx 2 N 66$ & $4 / 1$ & $4 / 1$ & $4 / 1$ & & 1 \\
\hline $2 \mathrm{~N} 113$ & $4 / 1$ & $4 / 2$ & - & & 2 \\
\hline Ackerperle & $1 / 1$ & $4 / 1$ & $2-3 / 1$ & & 1 \\
\hline$* 2 \mathrm{~N} 114$ & $2-3 / 1$ & $3 / 1$ & - & & 1 \\
\hline$* 2$ N94 & $3 / 1$ & $4 / 1$ & $2 / 1$ & & 1 \\
\hline $2 N 31$ & $4 / 1$ & $4 / 2$ & - & & 2 \\
\hline$* 2 \mathrm{~N} 236$ & $4 / 1$ & $2-3 / 1$ & $1-2 / 1$ & & 1 \\
\hline $2 \mathrm{~N} 63$ & $4 / 1^{+}$ & $3-4 / 2$ & - & & 2 \\
\hline$* 2 \mathrm{~N} 296$ & $4 / 1$ & $3-4 / 1$ & - & & 1 \\
\hline$* 2$ N37 & $2-3 / 1$ & $4 / 1$ & $4 / 1$ & & 1 \\
\hline $2 \mathrm{~N} 15$ & $2 / 1$ & $4 / 2$ & $3-4 / 2$ & & 2 \\
\hline$* 2 \mathrm{~N} 218$ & $3 / 1$ & $3 / 1$ & $4 / 1$ (5 plants) & & 1 \\
\hline$* 2 \mathrm{~N} 112$ & $4 / 1$ & $4 / 1$ & $3-4 / 1$ & & 1 \\
\hline$* 2 \mathrm{~N} 20$ & $4 / 1$ & $4 / 1$ & 4/2 (Diana) & & 2 \\
\hline $2 N 43$ & $2 / 1$ & $3 / 2$ & - & & 2 \\
\hline 2 N98 & $2 / 1$ & $4 / 2$ & - & & 2 \\
\hline $2 \mathrm{~N} 104$ & $3 / 1$ & $4 / 1$ & $4 / 1$ & & 1 \\
\hline $2 \mathrm{~N} 109$ & $2 / 1$ & $3-4 / 3$ & - & & 3 \\
\hline $2 \mathrm{~N} 242$ & $4 / 1$ & $4 / 2$ & - & & 2 \\
\hline
\end{tabular}




\begin{tabular}{|c|c|c|c|c|c|}
\hline & $I$ & II & III & Fina 1 & Score ${ }^{* *}$ \\
\hline $2 \mathrm{~N} 18$ & $4 / 1$ & $3-4 / 2$ & & & 2 \\
\hline $2 \mathrm{~N} 23$ & $3 / 1$ & $4 / 3$ & $4 / 3$ & & 3 \\
\hline$* 2 \mathrm{~N} 19$ & $2 / 1$ & $3-4 / 11$ & $3 / 1$ & & 1 \\
\hline $2 \mathrm{~N} 340$ & $3 / 1$ & $4 / 2$ & $4 / 2$ & & 2 \\
\hline 2 N96 & $4 / 3$ & $4 / 2$ & $3 / 3$ & & 3 \\
\hline $2 \mathrm{~N} 121$ & $4 / 2$ & $4 / 2$ & $3 / 11$ & & 2 \\
\hline$* 2 N 134$ & $4 / 1$ & $4 / 1$ & $4 / 11$ & & 1 \\
\hline$\approx 2 \mathrm{~N} 21$ & $2 / 1$ & $4 /-$ & $4 / 1$ & & 1 \\
\hline
\end{tabular}




$$
\text { APPENDIX 9. Analysis of variance. }
$$

Virulence patterns among Manitoba isolates of A. euteiches.

\begin{tabular}{lcccr}
\hline Source of variation & df & SS & MS & F \\
\hline Replications & 3 & 2.35 & 0.78 & 0.87 NS \\
$\quad$ Isolates & 2 & 33.87 & 16.94 & $19.03 * *$ \\
Error a & 6 & 5.35 & 0.89 & \\
Cultivars & 5 & 35.65 & 7.13 & $47.53 * *$ \\
Isolates $x$ cultivars & 10 & 70.35 & 7.03 & $46.86 * *$ \\
Error b & 30 & 4.60 & .15 & \\
CV main plot $=33.07 \%$ & & & & \\
CV sub plot $=13.73 \%$ & & & & \\
\hline
\end{tabular}

NS $=$ non-significant at $\mathrm{p}=.05$.

$* \omega=$ significant at $\mathrm{p}=.01$. 
APPENDIX 10. Analysis of variance.

Effect of the age of seedlings at inoculation time on disease.

1 - Fresh weight loss

\begin{tabular}{lrrrr}
\hline Source of variation & df & \multicolumn{1}{c}{ SS } & MS & F \\
\hline Total & & & & \\
Blocks & 2 & 129.45 & 64.72 & $19.49^{* * *}$ \\
Age & 2 & 8566.86 & 4283.43 & $1267.28^{* * *}$ \\
Error (a) & 4 & 13.52 & 3.38 & \\
& & & & $20.29 * *$ \\
Cultivars & 1 & 518.31 & 518.31 & $28.45^{* *}$ \\
Age x cultivars & 2 & 1454.07 & 727.31 & \\
Error (b) & 6 & 159.27 & 25.54 & \\
& & & & \\
CV (\%) Main plot (age) & $: 2.94$ & & \\
CV (\%) Subplot (varieties) $: 8.09$ & & \\
\hline
\end{tabular}

$2-\%$ plants killed

\begin{tabular}{lrrrr}
\hline Source of variation & df & \multicolumn{1}{c}{ SS } & MS & \multicolumn{1}{c}{ F } \\
\hline Total & & & & \\
Blocks & 2 & 89.48 & 44.74 & .84 NS \\
Age & 2 & 14585.54 & 7292.77 & $137.41^{\frac{4+6}{*}}$ \\
Error (a) & 4 & 212.28 & 53.07 & \\
Cultivars & 1 & 4255.95 & 4255.95 & $23.60^{*-*}$ \\
Age x cultivars & 2 & 1252.56 & 626.28 & 3.47 NS \\
Error (b) & 6 & 1081.86 & 180.31 & \\
CV (\%) Main plot $=$ & & & & \\
CV (\%) Subplots $=$ & & & & \\
\hline
\end{tabular}

NS $=$ Non-significant at $\mathrm{p}=.05$.

**significant at .01 . 
APPENDIX 11. Analysis of variance.

Temperature effect on disease (Fresh weight 1oss).

\begin{tabular}{|c|c|c|c|}
\hline Source of variation & $d f$ & MS & $\mathrm{F}$ \\
\hline Replications & 2 & 316.55 & $1.02 \mathrm{NS}$ \\
\hline Temperatures & 3 & 18597.87 & $60.47^{\frac{1}{n *}}$ \\
\hline Error a & 6 & 307.53 & \\
\hline Cultivars & 2 & 1076.50 & $15.20 \% *$ \\
\hline Temperatures $\mathrm{x}$ cultivars & 6 & 262.03 & $3.70^{*}$ \\
\hline Error b & 16 & 70.79 & \\
\hline$\% \mathrm{CV}$ Main $\mathrm{plot}=48.68$ & & & \\
\hline$\%$ CV Subplot $=23.35$ & & & \\
\hline
\end{tabular}

NS $=$ Non-significant at $\mathrm{p}=.05$.

*Significant at $\mathrm{p}=.05$.

Significant at $\mathrm{p}=.01$. 
APPENDIX 12. Inoculum density study - results.

\begin{tabular}{lcccc}
\hline & DSI (\%) & $\begin{array}{c}\% \text { Plants } \\
\text { killed }\end{array}$ & $\begin{array}{c}\text { Fresh weight/ } \\
\text { plant (g) }\end{array}$ & $\begin{array}{c}\text { Fresh weight } \\
\text { loss (\%) }\end{array}$ \\
\hline 0 & $0.0 \mathrm{c}^{+}$ & $0.0 \mathrm{~d}$ & $3.46 \mathrm{ab}$ & 0.00 \\
$10^{3}$ & $5.00 \mathrm{c}$ & $0.0 \mathrm{~d}$ & $3.49 \mathrm{a}$ & 0.00 \\
$10^{4}$ & $34.87 \mathrm{~b}$ & $0.0 \mathrm{~d}$ & $3.11 \mathrm{~b}$ & 10.12 \\
$2.10^{4}$ & $96.82 \mathrm{a}$ & $13.63 \mathrm{c}$ & $2.14 \mathrm{c}$ & 38.15 \\
$4.10^{4}$ & $100.00 \mathrm{a}$ & $36.36 \mathrm{~b}$ & $1.40 \mathrm{~d}$ & 59.53 \\
$10^{5}$ & $100.00 \mathrm{a}$ & $60.53 \mathrm{a}$ & $1.04 \mathrm{e}$ & 69.94 \\
\hline$\overline{\mathrm{X}}$ & 56.11 & 18.42 & 2.44 & \\
\hline LSD .01 & 13.84 & 17.69 & 0.35 & \\
\hline
\end{tabular}

Values represent the average of 5 replications.

treatments with same letters are not significantly different at $\mathrm{p}=.01$ (Duncan's Multiple Range Test). 
APPENDIX 13. Analysis of variance.

Inoculum density.

1 - (\% plants killed)

\begin{tabular}{lrrrr}
\hline Source of variation & df & \multicolumn{1}{c}{ SS } & MS & F \\
\hline Total & 29 & 17739.78 & 611.72 & \\
Treatments & 5 & 15680.30 & 3136.06 & $32.44^{* * *}$ \\
Blocks & 4 & 126.27 & 31.57 & 0.32 NS \\
Error & 20 & 1933.22 & 96.66 & \\
$\quad$ CV $(\%)=53.37$ & & & & \\
\hline
\end{tabular}

2 - Disease severity index (roots)

\begin{tabular}{lrrrr}
\hline Source of variation & df & \multicolumn{1}{c}{ SS } & MS & \multicolumn{1}{c}{ F } \\
\hline Tota 1 & 29 & 60306.60 & 2079.54 & \\
Treatments & 5 & 58609.41 & 11721.88 & $197.97^{* * *}$ \\
Blocks & 4 & 512.90 & 128.22 & 2.16 NS \\
Error & 20 & 1184.30 & 59.21 & \\
$\quad$ CV $(\%)=13.71$ & & & & \\
\hline
\end{tabular}

3 - Fresh shoot weight loss

\begin{tabular}{lrrrr}
\hline Source of variation & df & SS & MS & F \\
\hline Total & 29 & 29.43 & 1.01 & \\
Treatments & 5 & 28.59 & & $143.00^{* * *}$ \\
Blocks & 4 & 0.03 & 0.007 & .18 NS \\
Error & 20 & 0.80 & 0.04 & \\
$\quad$ CV $(\%)=8.19$ & & & & \\
\hline
\end{tabular}

NS = Non-significant.

** Significant at $\mathrm{p}=.01$. 
APPENDIX 14. Analysis of variance.

Assessment of yield loss.

1 - Yield in non-infested field

\begin{tabular}{lrrrr}
\hline Source of variation & df & SS & MS & F \\
\hline Total & 44 & 200461.91 & & \\
Blocks & 8 & 35599.91 & 4449.99 & 1.08 NS \\
Treatments & 4 & 33526.58 & 8381.64 & 2.04 NS \\
Error & 32 & 131335.42 & 4104.23 & \\
$\quad$ CV $(\%)=15.39$ & & & & \\
\hline
\end{tabular}

2 - Yield in infested field

\begin{tabular}{lrrrr}
\hline Source of variation & df & SS & MS & F \\
\hline Total & 44 & 178756.44 & & \\
Blocks & 8 & 46471.64 & 5808.96 & $4.35^{* *}$ \\
Treatments & 4 & 89552.44 & 22388.11 & $16.76^{* *}$ \\
Error & 32 & 42732.36 & 1335.39 & \\
$\quad$ CV $(\%)=19.95$ & & & & \\
\hline
\end{tabular}

3 - Yield loss

\begin{tabular}{lrrrr}
\hline Source of variation & df & \multicolumn{1}{c}{ SS } & MS & \multicolumn{1}{c}{ F } \\
\hline Tota1 & 44 & 10645.79 & & \\
Blocks & 8 & 2711.76 & 338.97 & $4.42^{* * *}$ \\
Treatments & 4 & 5479.54 & 1369.88 & $17.86^{\frac{1}{*} *}$ \\
Error & 32 & 2454.49 & & \\
$\quad$ CV $(\%)=15.66$ & & & & \\
\hline
\end{tabular}

NS = Non-significant.

* Significant at $\mathrm{p}=.01$. 
APPENDIX 15. Fungicides 1980.

1 - University of Manitoba, 1st date

\begin{tabular}{lrrrr}
\hline Source of variation & df & SS & MS & F \\
\hline Total & 89 & 13613.56 & & \\
Blocks & 8 & 2162.16 & 270.27 & $2.17^{*}$ \\
Treatments & 9 & 2520.89 & 280.10 & $2.25^{*}$ \\
Error & 72 & 8930.51 & 124.03 & \\
$\quad$ CV $(\%)=10.14$ & & & & \\
\hline
\end{tabular}

2 - University of Manitoba, 2nd date

\begin{tabular}{lrrrr}
\hline Source of variation & df & \multicolumn{1}{c}{ SS } & MS & F \\
\hline Total & 89 & 6729.29 & & \\
Blocks & 8 & 474.89 & 59.36 & .90 \\
Treatments & 9 & 1543.73 & 171.53 & $2.62^{*}$ \\
Error & 72 & 4710.67 & 65.43 & \\
$\quad$ CV $(\%)=6.62$ & & & & \\
\hline
\end{tabular}

3 - Eastern Manitoba

\begin{tabular}{lrrll}
\hline Source of variation & df & SS & MS & F \\
\hline Total & 89 & & \\
Blocks & 8 & 399.44 & $2.21^{*}$ \\
Treatments & 9 & 258.20 & 1.43 NS \\
Error & 72 & 180.16 & \\
$\quad$ CV $(\%)=14.05$ & & & \\
\hline
\end{tabular}

NS $=$ Non-significant at $\mathrm{p}=.05$.

${ }^{\star}$ Significant at $\mathrm{p}=.05$. 
APPENDIX 16. Analysis of variance.

Fungicide experiment, 1981.

1 - Plant emergence

\begin{tabular}{lrrrr}
\hline Source of variation & df & \multicolumn{1}{c}{ SS } & MS & F \\
\hline Total & 47 & 11610.67 & & \\
Blocks & 5 & 972.92 & 194.58 & .88 NS \\
Treatments & 7 & 2922.00 & 417.43 & 1.89 NS \\
Error & 35 & 7715.75 & 220.45 & \\
$\quad$ CV $(\%)=11.94$ & & & & \\
\end{tabular}

2 - Disease severity index, lst rating

\begin{tabular}{lrrrr}
\hline Source of variation & df & \multicolumn{1}{c}{ SS } & MS & F \\
\hline Total & 47 & 3566.21 & & \\
Blocks & 5 & 302.07 & 60.41 & 2.16 NS \\
Treatments & 7 & 2287.12 & 326.73 & $11.70^{* * *}$ \\
Error & 35 & 977.02 & 27.91 & \\
$\quad$ CV $(\%)=10.16$ & & & & \\
\end{tabular}

3 - Fresh shoot weights, 1st rating

\begin{tabular}{lrlll}
\hline Source of variation & df & SS & MS & F \\
\hline Total & 39 & 80.68 & & \\
Blocks & 4 & 12.55 & 3.14 & $3.45^{*}$ \\
Treatments & 7 & 42.51 & 6.07 & $6.67^{* *}$ \\
Error & 28 & 25.62 & 0.91 & \\
$\quad$ CV $(\%)=17.83$ & & & & \\
\hline
\end{tabular}

NS $=$ Non-significant at $\mathrm{p}=.05$.

${ }^{*}$ Significant at $\mathrm{p}=.05$.

** Significant at $\mathrm{p}=.01$. 
APPENDIX 17. Analysis of variance.

Fungicide experiment 1981, 2nd rating.

1 - Disease severity index

\begin{tabular}{lrrrr}
\hline Source of variation & df & \multicolumn{1}{c}{ SS } & MS & F \\
\hline Total & 47 & 2269.39 & & \\
B1ocks & 5 & 113.65 & 22.73 & .98 NS \\
Treatments & 7 & 1348.52 & 192.65 & $8.35^{* *}$ \\
Error & 35 & 807.22 & 23.06 & \\
$\quad$ CV $(\%)=8.55$ & & & & \\
\hline
\end{tabular}

2 - Fresh shoot weights

\begin{tabular}{lrrrr}
\hline Source of variation & df & \multicolumn{1}{c}{ SS } & MS & F \\
\hline Total & 47 & 369.06 & & \\
Blocks & 5 & 157.07 & 31.41 & $6.78^{* \%}$ \\
Treatments & 7 & 49.92 & 7.13 & 1.53 NS \\
Error & 35 & 162.08 & 4.63 & \\
$\quad$ CV $(\%)=19.45$ & & & & \\
\hline
\end{tabular}

NS $=$ Non-significant at $\mathrm{p}=.05$.

Significant at $\mathrm{p}=.01$. 